\title{
CDKN2A gene mutations and genetic interactions in the pathogenesis of melanoma
}

PhD dissertation

\section{Klára Balogh}

Supervisors:

Judit Oláh MD, PhD

Márta Széll PhD, DSc

Department of Dermatology and Allergology

University of Szeged

Szeged, Hungary 


\section{TABLE OF CONTENTS}

List of publications 3

List of abbreviations $\quad 4$

1. Introduction $\quad 5$

1.1. Malignant melanoma 5

1.1.1. Epidemiology 5

1.1.2. Predisposing factors 7

1.2. Familial Atypical Multiple Mole and Melanoma syndrome (FAMMM) 7

1.3. Structure and function of the cyclin dependent kinase inhibitor 2A (CDKN2A) gene 8

1.4. Structure and function of the melanocortin-1 receptor (MC1R) gene 10

1.5. Aims 12

2. Patients and methods 13

2.1. Enrolment of patients to the study 13

2.2. Genetic studies 14

2.2.1. Case history 1 and details of the genetic analysis 14

2.2.2. Case history 2 and details of the genetic analysis 16

2.2.3. Case history 3 and details of the genetic analysis 18

3. Results 20

3.1. Detection of the rare P48T mutation in the CDKN2A gene and melanoma susceptibility related MC1R polymorphisms 20

3.2. Detection of the R24P CDKN2A mutation in association with multiple primary malignancies including melanoma 22

3.3. Detection of the rare IVS1+37 G/C intronic mutation $\begin{array}{ll}\text { and its role in splicing regulation } & 23\end{array}$

4. Discussion 26

5. Summary 35

6. Acknowledgements 36

7. Magyar nyelvü összefoglaló

8. References 41 


\section{LIST OF PUBLICATIONS}

\section{Publications directly related to the subject of the dissertation}

I. Széll M, Balogh K, Dobozy A, Kemény L, Oláh J. First detection of the melanomapredisposing proline-48-threonine mutation of p16 in Hungarians: was there a common founder either in Italy or in Hungary? Melanoma Res. 2007; 17(4):251-4.

IF: 2.225

II. Balogh Klára, Széll Márta, Dobozy Attila, Kemény Lajos, Oláh Judit. A CDKN2A gén ritka, ivarsejtvonal-beli mutációja egy multiplex primer melanomában szenvedő betegben és családjában. Börgyógy.Vener. Szle. 2008; 84: 71-75.

III. Balogh K, Széll M, Polyánka H, Pagani F, Bussani E, Kemény L, Oláh J. Detection of a rare CDKN2A intronic mutation in a Hungarian melanoma-prone family and its role in splicing regulation. Br J Dermatol. 2012; 167(1):131-3.

IF: 3.666

IV. Klára Balogh, Edina Nemes, Gabriella Uhercsák, Zsuzsanna Kahán, György Lázár, Gyula Farkas, Hilda Polyánka, Erika Kiss, Rolland Gyulai, Erika Varga, Erika Keresztné Határvölgyi, Kaizer László, Lajos Haracska, László Tiszlavicz, Lajos Kemény, Judith Oláh, Marta Széll. Melanoma-predisposing CDKN2A mutations in association with breast cancer: a case-study and review of the literature. 'Chapter 13'in Melanoma in the Clinic - Diagnosis, Management and Complications of Malignancy; InTech Open Access Publisher (ISBN 978953-307-293-7.); 2011

\section{Publication indirectly related to the subject of the dissertation}

V. Zsanett Csoma, Edit Tóth-Molnár, Klára Balogh, Hilda Polyánka, Hajnalka Orvos, Henriette Ócsai, Lajos Kemény, Marta Széll and Judith Oláh. Neonatal blue light phototherapy and melanocytic nevi: a twin study. Pediatrics. 2011; Oct;128(4):e856-64.

IF : 5.437 


\section{LIST OF ABBREVIATIONS}

ACTH

alpha-MSH

ARF

ASIP

BOLD

bp

BRCA 1

BRCA 2

CDK4

CDKN2A

DNA

FAMMM

FAMMM-PC

MC1R

MIM

mRNA

NRHC

nt

$\mathrm{p} 16 / \mathrm{p} 16^{\mathrm{INK} 4 \mathrm{~A}}$

$\mathrm{p} 14 / \mathrm{p} 14^{\text {ARF }}$

PCR

$\mathrm{Rb}$

RHC

RNA

UK

US

UV
Adrenocorticotrop hormone

Alpha-melanocyte stimulating hormone

Alternate reading frame

Agouti signaling protein

Bleomycin-Vincristine-Lomustine-Dacarbazine chemotherapy

Base pair

Breast cancer type 1 susceptibility gene

Breast cancer type 2 susceptibility gene

Cyclin dependent kinase 4

Cyclin dependent kinase inhibitor 2A

Desoxyribonucleic acid

Familial atypical multiple mole and melanoma syndrome

Familial atypical multiple mole melanoma and pancreatic cancer syndrome

Melanocortin-1 receptor

Mendelian inheritance in man

Messenger ribonucleic acid

Non-red hair colour

Nucleotide

Protein product of the CDKN2A gene

Protein product of the CDKN2A gene with an alternative reading frame

Polymerase chain reaction

Retinoblastoma gene/protein

Red hair colour

Ribonucleic acid

United Kingdom

United States

Ultraviolet 


\section{INTRODUCTION}

\subsection{Malignant melanoma}

Malignant melanoma is a malignancy developing from the melanocytes of the skin, mucous membranes and ectopic melanocytes such as those of the eye (uvea) and the nervous system (meninges). It can develop either from benign melanocytic lesions or de novo. The prevalence of melanoma is relatively low compared to all cancers. However, it has the highest mortality rate among skin cancers which underlines the importance of the awareness of the predisposing factors and prevention, as well as early diagnosis and treatment.

\subsubsection{Epidemiology}

The incidence of cutaneous malignant melanoma has been increasing worldwide. Data collected from the National Cancer Registry of Hungary ${ }^{1}$ are consistent with these statistics (Figure 1 - 2). The number of patients diagnosed with melanoma in Szeged has multiplied over the last few decades. In the context of these data it is important to mention that the first awareness and screening event in Szeged happened in 1996, and since 2000 there is an annual "Melanoma Awareness" day with campaign screening which contributed to the cancer pick-up rate ${ }^{2}$. Unlike other malignancies, skin cancers including melanoma can often be diagnosed by simple clinical examination. If diagnosed and treated early, most patients have the potential for full recovery and remain tumour free. However, the number of those who present with advanced disease and metastases is still very high in Hungary. Sadly, a considerable number of patients develop melanoma at a young age therefore in their case the number of the potentially lost years of life is high. Moreover, the number of patients who see the dermatologist with advanced melanoma has not significantly decreased yet, which can explain the relatively high mortality rate in our country ${ }^{3}$. 


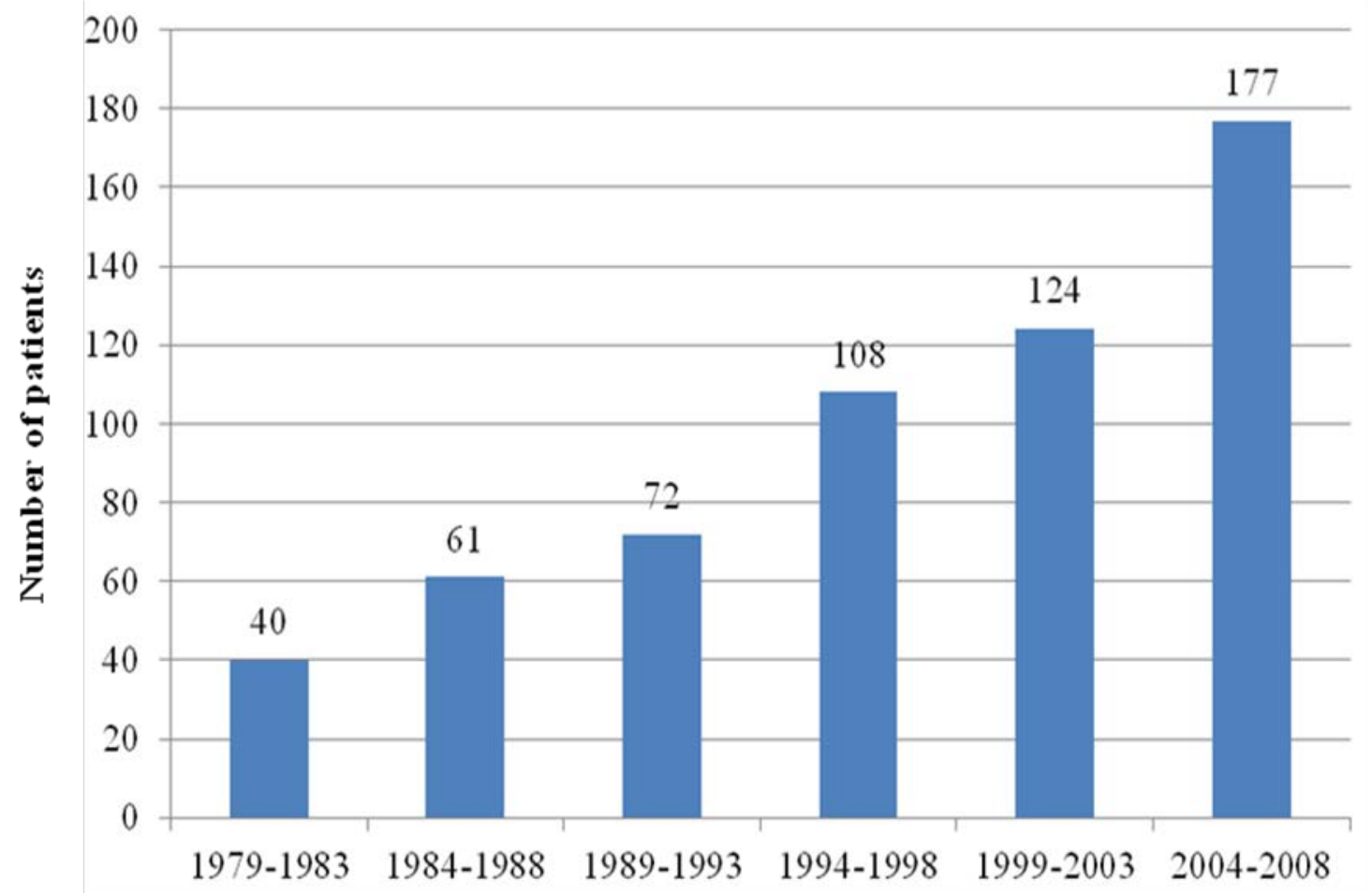

Figure 1. The number of registered melanoma patients in Szeged in five-yearly breakdown (after Oláh and Korom, Dermatology lecture of the academic year 2012/2013) ${ }^{2}$

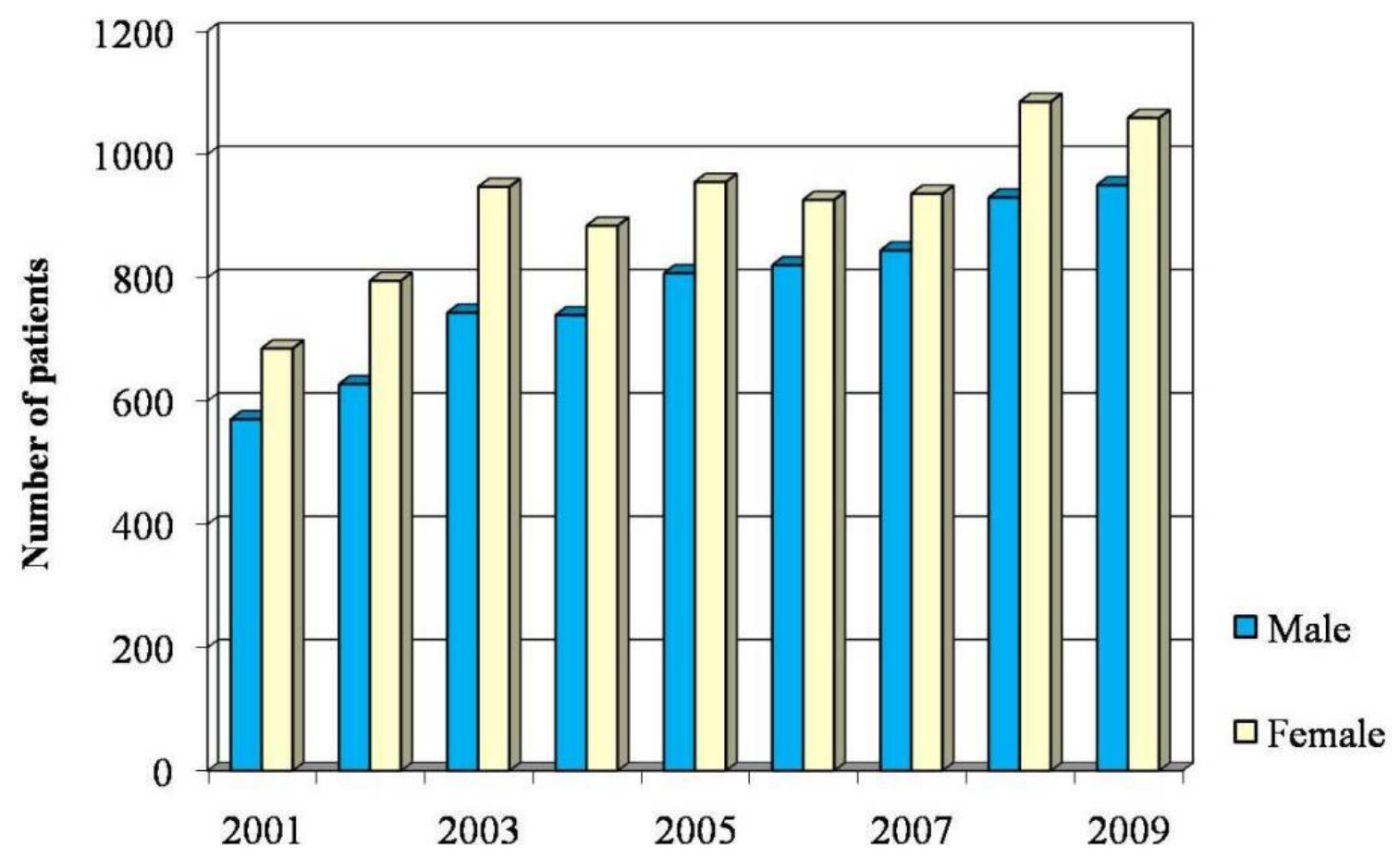

Figure 2. The number of registered melanoma patients in Hungary in annual breakdown (after Oláh and Korom, Dermatology lecture of the academic year 2012/2013) ${ }^{2}$ 


\subsubsection{Predisposing factors}

It is well known that the major environmental predisposing factor for melanoma is UV exposure. Multiple severe sunburns, especially if suffered in childhood, as well as extensive sunbed use, sunbathing - particularly intermittent UV exposure - are the main extrinsic predisposing factors. Constitutional factors such as fair skin, inability to tan, freckling, red hair colour phenotype, the presence of multiple or larger than $5 \mathrm{~mm}$ common melanocytic nevi, dysplastic nevi, giant congenital nevi also contribute to melanoma predisposition. In addition to this, past history or family history of melanoma as well as Familial Atypical Multiple Mole and Melanoma (FAMMM) syndrome along with certain associated gene mutations and polymorphisms are known contributors to melanoma susceptibility.

The climate of Hungary is continental and it is situated relatively distant from the Equator. However, in terms of the strength of UV radiation the risk of suffering significant UV photodamage during summer months is similar to that in the Mediterranean climate. The number of sunny hours in Hungary exceeds 2000 hours per year. Approximately two third of the Hungarian population belongs to Fitzpatrick skin type II/III which means that their skin burns easily, tans poorly hence they are more susceptible to developing skin cancer including malignant melanoma ${ }^{3}$.

\subsection{Familial Atypical Multiple Mole and Melanoma syndrome (FAMMM)}

Familial cutaneous melanoma accounts for approximately $10 \%$ of all melanoma cases ${ }^{4}$. It is well-known from clinical practice that familial melanoma often presents with multiple primary melanomas and clinically atypical moles and it is usually diagnosed at a much younger age than sporadic cutaneous melanoma ${ }^{5}$.

The criteria of FAMMM syndrome are the following (all of them): (1) malignant melanoma in one or more first- or second-degree relatives, (2) high total body nevi count (often >50) including some of which are clinically atypical (polychrome asymmetric irregular shaped lesions with macular component) and (3) nevi with certain histological features on microscopy. Cancer risks reported for FAMMM vary widely ${ }^{6-10}$.

The genetic predisposition to melanoma is quite heterogeneous. The complex genetic network involved in melanoma proliferation, progression and survival as well as the genes involved in melanocyte development and survival has been investigated extensively by many groups over the last three decades and has been recently summarised in a review article by 
Lin J et al. ${ }^{11}$. These studies contributed to the framework of our current understanding of the genetic factors and gene-environmental interactions in the pathogenesis of melanoma.

Genetic linkage analyses in large melanoma pedigrees identified the cell-cycle regulatory cyclin-dependent kinase inhibitor 2A (CDKN2A/p16INK4A) gene on chromosome 9p21 as a major locus for melanoma predisposition ${ }^{12}$. Germline mutations of the gene within this

chromosomal region are responsible for melanoma susceptibility ${ }^{13,14}$ though alterations in it have been detected in only $20-40 \%$ of melanoma-prone families ${ }^{9,15}$.

CDKN2A mutation prevalence in FAMMM is $25-40 \%$. The penetrance of melanoma in CDKN2A mutation carriers is approximately $60-90 \%$ by age 80 and for pancreatic cancer it is about $17 \%$ by age 75 . The cancer risk of FAMMM patients not carrying a CDKN2A mutation is unclear ${ }^{10}$.

\subsection{Structure and function of the CDKN2A gene}

The CDKN2A gene (MIM 600160) generates a couple of transcript variants from its four exons: 1b, 1a, 2 and 3, as a result of alternative splicing. Two transcript variants encode structurally related isoforms known to function as inhibitors of the CDK4 kinase (Figure 3). Transcript variant 1 encodes the p16 (also known as INK4a or p16 ${ }^{\mathrm{INK} 4 \mathrm{~A}}$ ) protein, which is encoded by exons 1a, 2 and 3. Transcript variant 3, encoding the p12 isoform is rarely mentioned in the context of melanoma. It was described by Robertson and Jones ${ }^{16}$ and in their study it showed a strict pancreas-specific expression, with a first exon including a 274ntintronic part flanking the 5' end of exon 1a and sharing exons 2 and 3 of the other isoforms. The recognition of the 274-nt sequence as an exon in case of the pancreas specific variant results in a different reading frame and an earlier stop codon. Transcript variant 4 includes an alternate first exon (1B) located $20 \mathrm{~Kb}$ upstream of the remainder of the gene resulting in an alternate open reading frame (ARF) that specifies a protein which is structurally unrelated to the products of the other variants.

Variations in the CDKN2A intronic sequences have been reported in association with melanoma either or not directly affecting the splice sites ${ }^{6-9}$.The inclusion of a cryptic exon of the CDKN2A gene has been described in human cancer cell lines: the p16gamma isoform (and the mRNA referred to as transcript variant 5), includes a 197-nt sequence between exons 2 and 3 and the expressed protein acts as a cell-cycle inhibitor ${ }^{11,17}$. 


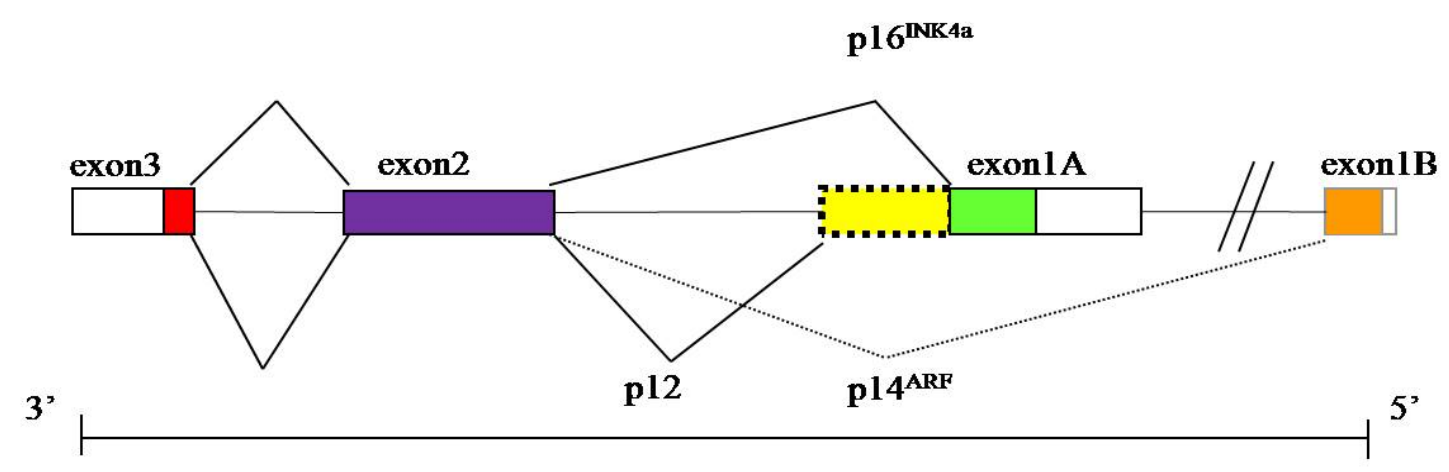

CDKN2A spliced mRNA

transcript variant 1

transcript variant 3

transcript variant 4
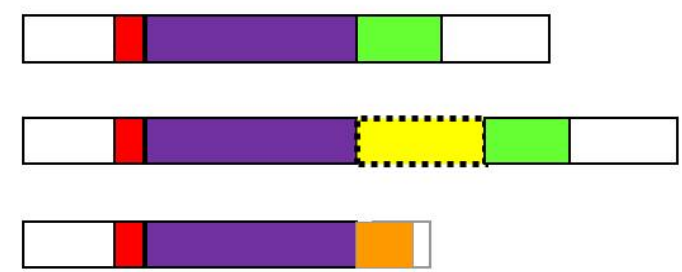

CDKN2A protein

p16 $6^{\mathrm{INK} 4 \mathrm{a}}$

p12 (pancreas)

p14 ${ }^{\mathrm{ARP}}$

Figure 3. Structure of the CDKN2A gene, the related mRNA transcripts and proteins

The two main tumour suppressor proteins encoded by CDKN2A, are the $\mathrm{p} 16^{\mathrm{INK} 4 \mathrm{a}}$ and the $\mathrm{p} 14^{\mathrm{ARF}}$ (alternative reading frame), both of which are thought to contribute to senescence and tumour growth restriction. The main function of these is preventing cell cycle progression via two separate pathways. p16 ${ }^{\mathrm{INK} 4 \mathrm{~A}}$ binds to the CyclinD-CDK4/6 complex inhibiting the CDK4/6-mediated phosphorylation of the retinoblastoma protein (Rb). In the hypophosphorylated state, Rb binds and represses the E2F transcription factor and prevents $\mathrm{G}_{1}$-to-S transition. p14 ${ }^{\mathrm{ARF}}$ directly prevents MDM2 from accelerating the degradation of p53. Therefore, loss of the CDKN2A locus negatively impacts on both the Rb and p53 pathways $^{11}$ (Figure 4). 


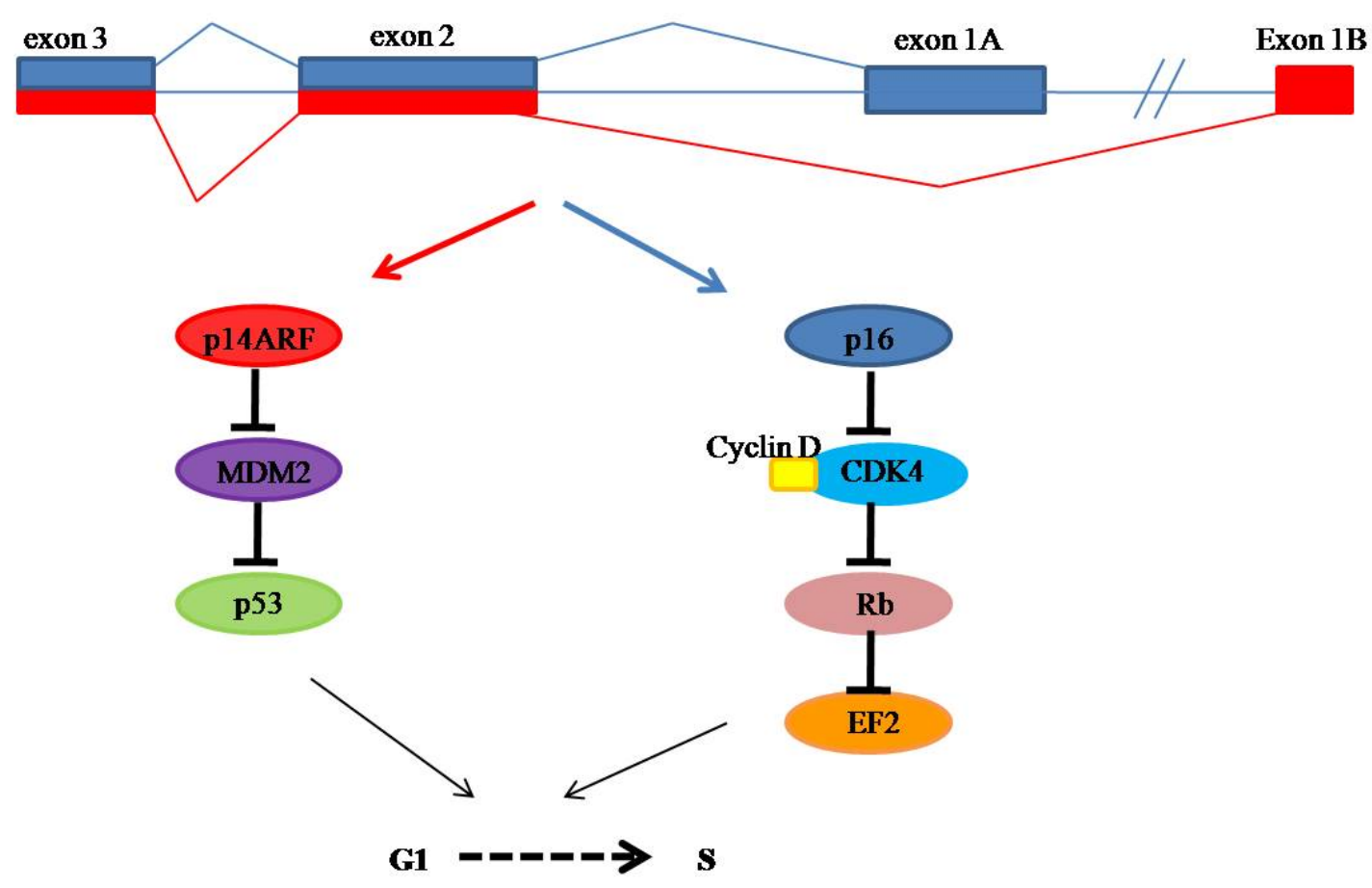

Figure 4. The CDKN2A pathway (after Lin et al. 2008) ${ }^{11}$

\subsection{Structure and function of the melanocortin-1 receptor (MC1R) gene}

The melanocortin-1 receptor gene (MC1R, MIM 155555) with a 951-bp long single exon, is a key determinant of normal human pigmentation and sun sensitivity. It is located on chromosome 16 (16q24.3) and encodes the receptor protein for the alpha-melanocyte stimulating hormone (alpha-MSH). MC1R is a seven-pass transmembrane, G-protein coupled receptor expressed in human cutaneous and hair follicle melanocytes, involved in the regulation of melanogenesis. MC1R expression is upregulated by UV radiation and melanocortins (e.g. adrenocorticotrop hormone [ACTH], alpha-MSH). Binding of alphaMSH to the MC1R in the cell membrane initiates a G-protein coupled intracellular signaling which leads to pigment production, the balance of which varies according to the several existing MC1R variants but results in predominantly eumelanin production in individuals with a wild type MC1R. Eumelanin (brown/black pigment) is photoprotective while pheomelanin (yellow/red pigment) generates free radicals upon UV radiation therefore may contribute to UV-induced skin damage. MC1R activation can be inhibited by Agoutisignaling protein (ASIP) reducing melanogenesis and related processes. Melanin is stored in 
melanosomes which can be distributed to neighboring keratinocytes to protect them from UV-induced DNA damage ${ }^{18,19}$ (Figure 5.).
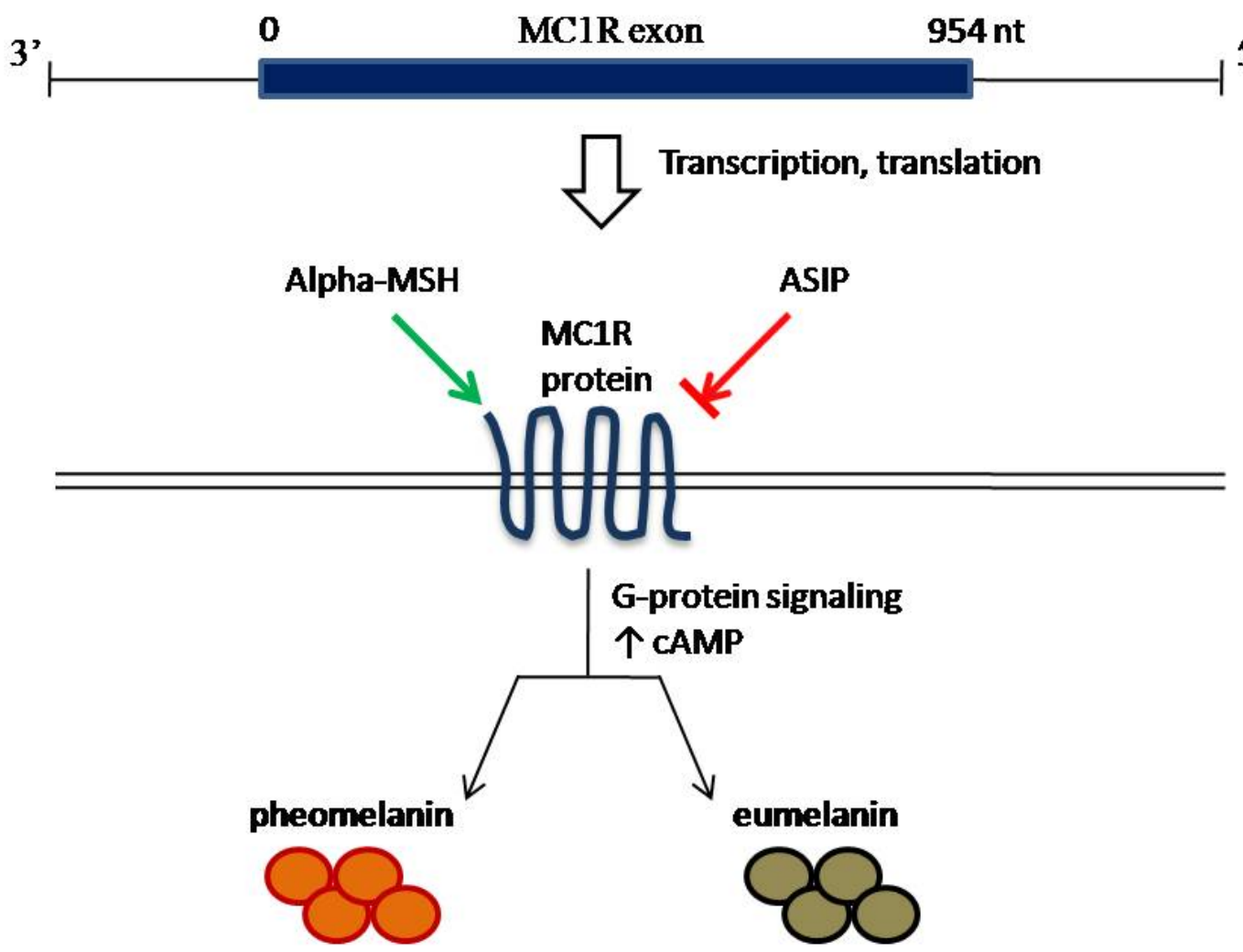

Figure 5. The MC1R gene and melanin production (after Garcia-Borrón, 2008 and Law et al, 2012) ${ }^{18,19}$

The MC1R locus is highly heterogeneous, especially in individuals of Caucasian descent. Certain MC1R variants have been associated with the so called "red hair colour" (RHC) phenotype that is red hair, fair skin, freckling and inability to tan, while many other and less frequently detected types are called "non-red hair colour” (NRHC) variants. MC1R has consistently shown to be a low-penetrance melanoma susceptibility gene in many studies worldwide and its role in modifying the penetrance of other gene mutations has been intensively investigated ${ }^{20-24}$. 


\subsection{Aims}

The frequency of CDKN2A mutations and the proportion of families with the most frequent founder mutations of each locale vary remarkably across geographical areas as demonstrated in a GenoMEL study comparing seven regions across Europe, North America, Asia and Australia ${ }^{9}$. Our aims were to gather data on the frequency and pattern of CDKN2A mutations and polymorphisms in Hungarian melanoma prone families in order to be able to compare CDKN2A mutation detection rates in Hungarian patients to those in the European and world population. We also aimed our work at contributing to the understanding of the genetic factors and the gene-environmental interactions - including the role of MC1R polymorphisms - in the pathogenesis of melanoma. 


\section{PATIENTS AND METHODS}

\subsection{Enrolment of patients to the study}

The Department of Dermatology and Allergology runs a well established Dermato-Oncology service serving the population of Csongrád, Békés and Bács-Kiskun counties. Patients with suspected skin cancer, including melanoma, are referred by general practitioners, primary dermatology services (e.g. Bőr-és Nemibeteg Gondozó) or directly from the general dermatology clinics of the department, while some patients are picked up by campaign screening such as the annual Regional Melanoma Day. Once the diagnosis of melanoma is established, histology results and management plan are discussed at the weekly multidisciplinary team meetings (so called OnkoTeam). The regular follow-up provides the opportunity to enrol family members of our patients into screening in case the early presentation of melanoma or family history of the disease is suggestive of an inherited susceptibility to cancer. The usual practice is to extend follow-up beyond the standard 5-year period therefore most of our melanoma patients are offered lifelong care.

Patients and their relatives were recruited from the Dermato-Oncology clinics of the department. Patients who presented with (1) melanoma affecting at least one first- or seconddegree relative, (2) melanoma and at least one first- or second degree relative with atypical moles and/or high total body nevi count and/or melanoma (FAMMM), (3) multiple primary melanoma and (4) melanoma with presentation of other malignancies in the patient or family members, especially pancreatic cancer (FAMMM-PC syndrome) were offered participation in genetic testing. The human samples used in this study were taken after written informed consent of the enrolled patients and family members. The protocol was approved by the Local Ethics Committee and adherent to the Helsinki guidelines. Over 120 samples from melanoma prone families were tested for germline genetic alterations in the CDKN2A gene. The four exons and flanking intronic sequences of the CDKN2A gene were amplified using methods detailed below at the individual chapters. In the current chapter, the author would like to highlight three clinical cases in which the results of genetic analysis were found remarkable in view of current data on CDKN2A mutations. 


\subsection{Genetic studies}

\subsubsection{Case history 1 and details of the genetic analysis}

A 30-year-old Caucasian male presented to our department in 1997 with a thick ulcerated nodular melanoma (pT3b) in the right femoral region (Figure 6a). He also had features of a sporadic form of multiple atypical mole syndrome (Figure 6b-c). At the time of diagnosis of the primary tumour in the right femoral region which was already $2 \mathrm{~cm}$ in size and bleeding, two early primary melanomas were also diagnosed on his trunk (indicated by arrows in Figure 6b-c). After removal of the three primary melanomas, he underwent delayed elective radical lymph node dissection of the right inguinal region. (The patient was treated according to the accepted medical practice at the time of his presentation, i.e. elective radical lymph node block dissection in case of a melanoma with more than $1.5 \mathrm{~mm}$ Breslow thickness. After recent changes in the guidelines on the management of melanoma in Hungary, current practice is doing a sentinel lymph node biopsy before radical interventions.)

The lymph node metastasis was an indication for interferon alpha $2 \mathrm{~b}$ therapy; therefore the patient was treated with 10 million units/3 tw interferon alpha $2 b$ for 3 months. During immunotherapy, the patient developed leucopenia and thrombocytopenia and he refused continuation of the treatment. During the 8-year follow-up period, further five new early melanomas developed. There was no internal organ involvement for as long as 7 years. In 2004, intra-abdominal lymph node metastases were found. The patient was treated with bleomycin, vincristine, lomustine and dacarbazine (BOLD) polychemotherapy, which resulted in a slight regression of the metastatic mass. At the end of year 2004, radiotherapy was started to treat the chemo resistant tumour mass in the iliac and retroperitoneal regions. After irradiation, his general condition remained satisfactory for 3 months, with regression of the metastatic lymph nodes. In July 2005, however, intrahepatic metastases were found. At the end of year 2005, the patient died from multiple liver, lung and intracranial metastases. 

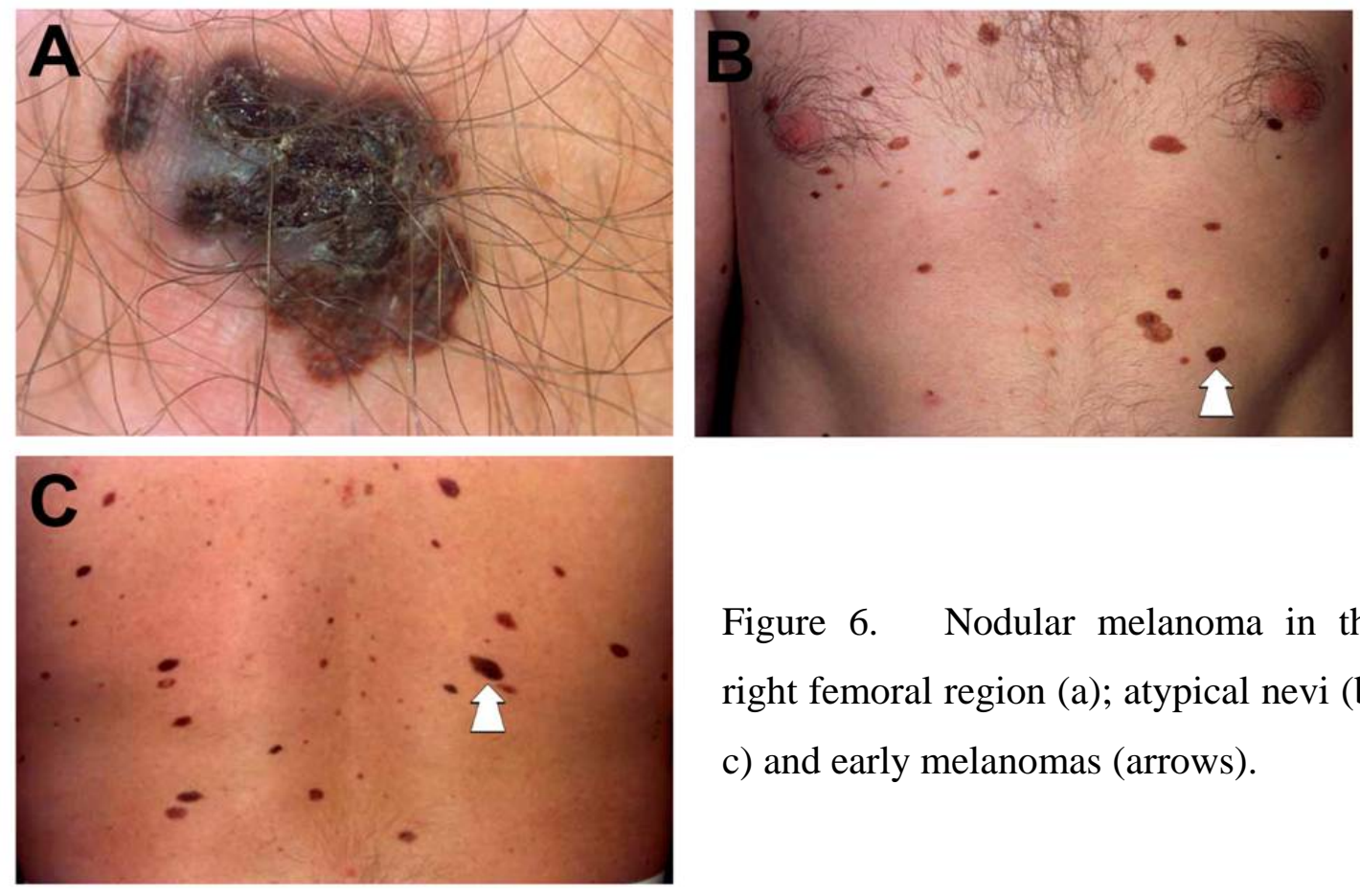

Figure 6. Nodular melanoma in the right femoral region (a); atypical nevi (bc) and early melanomas (arrows).

The presentation of multiple primary melanomas at a relatively young age and the presence of numerous atypical nevi suggested a genetic predisposition to melanoma; therefore we decided to investigate whether there was any alteration of the CDKN2A gene in the background. $2 \mathrm{ml}$ of venous blood was taken. Genomic DNA was isolated by using the Genomic DNA Purification Kit of Gentra (Minneapolis, MN, USA) and exons 1A, 1B, 2 and 3 of the CDKN2A gene were amplified under previously reported conditions ${ }^{25}$. The PCR products were purified using the Quantum Prep PCR Kleen Spin Columns of Bio-Rad (Hercules, CA, USA). Sequence analysis revealed a homozygote 142C $>$ A transition, which translates the P48T. The mutation was detected in exon $1 \mathrm{~A}$, which means that it affects the fifth amino acid of the second ankyrin repeat of $\mathrm{p} 16^{\mathrm{INK} 4 \mathrm{~A}}$ protein but the protein sequence of $\mathrm{p} 14^{\mathrm{ARF}}$ is unaffected.

After detecting this rare mutation in a homozygous form in our patient, we conducted genetic analysis of his parents, his 6-year-old daughter and his wife (Figure 7a). The father and the mother - age 69 and 63 - had no history of any malignancy and both are free of any atypical moles. They were not aware of consanguinity or the occurrence of familial melanoma among their relatives. Oral swabs were taken from the family members and genomic DNA was isolated from the samples with the MagNA Pure Compact system (Roche, Mannheim, Germany). Exon 1A was sequenced with the Resequencing Amplicon 
probe system (http://www.ncbi.nlm.nih.gov/genome/probe/reports/probereport), probe ID: RSA001284450.

Based on data that MC1R gene polymorphisms have the potential to contribute to melanoma susceptibility in CDKN2A mutation carriers and non-carriers independently of skin type $\mathrm{e}^{26,27}$, we also performed sequence analysis of the MC1R in all the family members. The whole length of the only exon of MC1R gene was amplified using methods detailed in the paper of Széll et al. ${ }^{28}$.

\subsubsection{Case history 2 and details of the genetic analysis}

The second highlighted case is of a 33-year-old female patient who developed melanoma, metachronous ductal adenocarcinoma of the breast and primary pancreas adenocarcinoma. The three tumours developed independently of each other. Although it is important to note that there are several dysplastic nevi and evidence of photodamage on her skin, past medical history of the patient was otherwise unremarkable. During the course of the treatment, her family history of malignancies was investigated. The patient reported that her father suffered from gastric and laryngeal carcinoma and that her paternal aunt had died from breast cancer at a young age several decades ago (Figure 8a). The occurrence of multiple primary tumours in a relatively young individual, together with the family history of different types of cancers, suggested that there might be genetic predisposition to develop multiple malignancies. We therefore set out to perform genetic investigations and check whether there are any cancer predisposing factors, causing the high prevalence of consecutively appearing independent primary malignancies in the patient and in her family.

DNA from venous blood was isolated using the QIAmp DNA Blood Mini Kit (Qiagen, Hilden, Germany) and exons 1A, 1B, 2 and 3 of the CDKN2A gene were amplified with the Resequencing Amplicon probe system (http://www.ncbi.nlm.nih.gov/genome/probe/reports/probereport; probe IDs: RSA001284450, RSA000045423, RSA000942236, RSA000942233). The PCR products were purified using the Quantum Prep PCR Kleen Spin Columns (Bio-Rad, Hercules, CA, USA) as in our previous experiments. Because of the occurrence of breast adenocarcinoma in our patient's medical history, it was also tested whether she carried mutations in the BRCA1 and BRCA2 genes. The 15 most common (so-called 'hot spot') BRCA mutations were studied (Table 1) using external service (Delta Bio $2000 \mathrm{Kft}$.). 


\begin{tabular}{|c|c|}
\hline Gene and Mutation & Primers \\
\hline \multirow{2}{*}{ BRCA1 3135delCATT } & TCTGGGTCCTTAAAGAAACAAAGTC \\
\hline & ACTTGGAATGTTCTCATTTCCC \\
\hline \multirow{2}{*}{ BRCA1 3153delAG } & CATCTCAGTTCAGAGGCAACG \\
\hline & TGCATGACTACTTCCCATAGGC \\
\hline \multirow{2}{*}{ BRCA1 3875delGTCT } & TCACCCATACACATTTGGCTC \\
\hline & AATCCATGCTTTGCTCTTCTTG \\
\hline \multirow{2}{*}{ BRCA1 4184delTCAA } & CGTTGCTACCGAGTGTCTGTC \\
\hline & GACGTCCTAGCTGTGTGAAGG \\
\hline \multirow{2}{*}{ BRCA1 185delAG } & GGTTGGCAGCAATATGTGAAA \\
\hline & TGCAGAACCAATCAAGACAGA \\
\hline \multirow{2}{*}{ BRCA1 300T $>$ G } & GGCTCTTAAGGGCAGTTGTG \\
\hline & AGAAAGGCAGTAAGTTTCTAATACCTG \\
\hline \multirow{2}{*}{ BRCA1 1294del40 } & TGTAATGATAGGCGGACTCCC \\
\hline & CTCAGGATGAAGGCCTGATG \\
\hline \multirow{2}{*}{ BRCA1 2382GT } & GACATGACAGCGATACTTTCCC \\
\hline & TGTTGCACATTCCTCTTCTGC \\
\hline \multirow{2}{*}{ BRCA1 5382insC } & GTGTCTGCTCCACTTCCATTG \\
\hline & CGAGACGGGAATCCAAATTAC \\
\hline \multirow{2}{*}{$\begin{array}{l}\text { BRCA2 6079delAGTT, 6174delT, } \\
\text { 6274delT }\end{array}$} & GTTGTTACGAGGCATTGGATG \\
\hline & GGAAACTTGCTTTCCACTTGC \\
\hline \multirow{2}{*}{ BRCA2 8034insAG } & TATGGCAGATTTAGCAGGAGG \\
\hline & TCGAGAGACAGTTAAGAGAAGAAAGA \\
\hline \multirow{2}{*}{ BRCA2 8138delCCTTT } & CTGGCCTCAAGCAATCCTC \\
\hline & TTGACATGGAAGTCACAGACTACAC \\
\hline \multirow{2}{*}{ BRCA2 9326insA } & TCCACTACTAATGCCCACAAAG \\
\hline & CACCTCAGAACAAGATGGCTG \\
\hline
\end{tabular}

Table 1.The 15 most common hotspot mutations of the BRCA1 and BRCA2 genes and the primers used for the amplification of the surrounding genetic regions 


\subsubsection{Case history 3 and details of the genetic and functional analysis}

Investigations in an extensive Hungarian family with FAMMM syndrome were carried out in collaboration with the Human Molecular Genetics Laboratory at the International Centre for Genetic Engineering and Biotechnology (ICGEB), Trieste, Italy.

Detailed analysis of the family tree revealed other malignancies beside melanoma. The genetic analysis of family members in branches B and C was carried out using the same methods as previously detailed under Case 2. Unfortunately, members in Branch A were not available for genetic screening. However, collateral history revealed that individual III/2 died from lung carcinoma and individual IV/1 developed prostate carcinoma at a young age (Figure 9). Detection of an intronic mutation (IVS1+37 G/C) of the CDKN2A gene in several family members led to further functional investigations.

The manifestation of atypical nevi andor melanoma in nearly all family members carrying the IVS1+37 G/C mutation in intron 1 of the CDKN2A gene, along with the family history of other malignancies, led to the hypothesis that the mutation may result in aberrant splicing and that the aberrant mRNA may play a pathogenetic role in the development of melanoma. Unfortunately, the members of the melanoma-prone Hungarian family declined providing skin biopsy specimens to facilitate the in vivo identification of the alternative CDKN2A splice variants. We therefore conducted in vitro functional analysis to investigate whether the IVS1+37 G/C intronic mutation had any effect on splicing regulation.

Two minigenes were constructed: one that harboured the wild-type and one that harboured the mutant allele of CDKN2A (Figure 10a). To investigate the effects of the mutation on splicing, HeLa cells were transfected with the wild-type and mutant minigenes. Transfection was carried out with the Turbofect reagent (Fermentas, Vilnius, Lithuania). The cells were cultured for 24 hours and total RNA was isolated using the TRI Reagent Solution (Applied Biosystems, Foster City, CA, U.S.A.). Reverse transcription was performed with the iScript cDNA Synthesis Kit (BioRad, Hercules, CA, U.S.A.) and the splice variants were detected with PCR. T7 and Sp6 primers were used for the pcDNA3 vector in order to avoid the amplification of internal CDKN2A transcripts. PCR reactions were performed in GoTaqHot Start mix (Promega, Madison, WI, U.S.A.). The PCR products were run on 2\% agarose gel and photographed, and the bands were purified from the gel and sequenced (Figure 10b).

In addition to CDKN2A studies in the family, the MC1R gene was also amplified and the 951-bp coding region was sequenced in two overlapping fragments using the same methods 
as described earlier ${ }^{28}$. Sequences were analysed using the BioEdit software (available at http://www.mbio.ncsu.edu/BioEdit/bioedit.html). 


\section{RESULTS}

\subsection{Detection of the rare P48T mutation in the CDKN2A gene and melanoma susceptibility related MC1R polymorphisms}

In case of the young male patient with multiple primary melanoma and unaffected family members (case 1), sequence analysis of the four exons of the CDKN2A gene revealed a homozygote $142 \mathrm{C}>\mathrm{A}$ transition in exon $1 \mathrm{~A}$, which causes a proline-threonine amino acid change at codon position 48 (P48T) (Figure 7c). The single nucleotide change in exon 1A affects the fifth amino acid of the second ankyrin repeat of p16 protein, while the protein sequence of ARF remains unaffected. As demonstrated in Figure 7b, the patient's father, mother and daughter are all heterozygote carriers of the $142 \mathrm{C}>\mathrm{A}$ mutation and the wife of the patient harbours the wild-type allele. Our results suggest that the patient had inherited one mutant allele from his father and one from his mother, and further transmitted the mutant allele to his daughter. There were no other mutations detected in the exon sequences of the CDKN2A gene in the patient. 
A

B

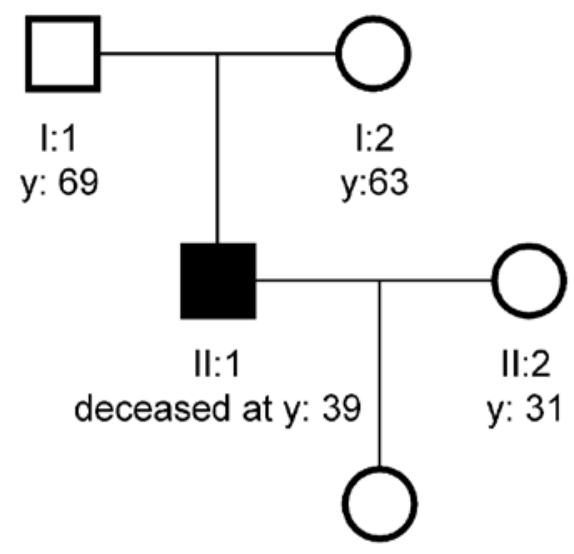

III:1

y: 6

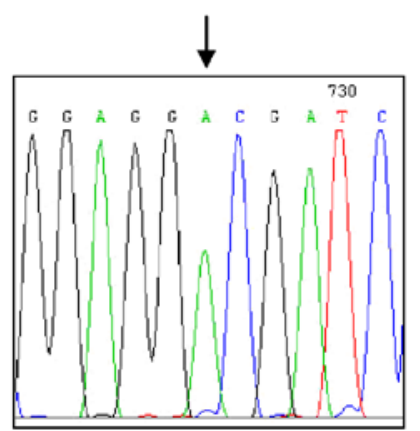

II:1 homozygote mutant
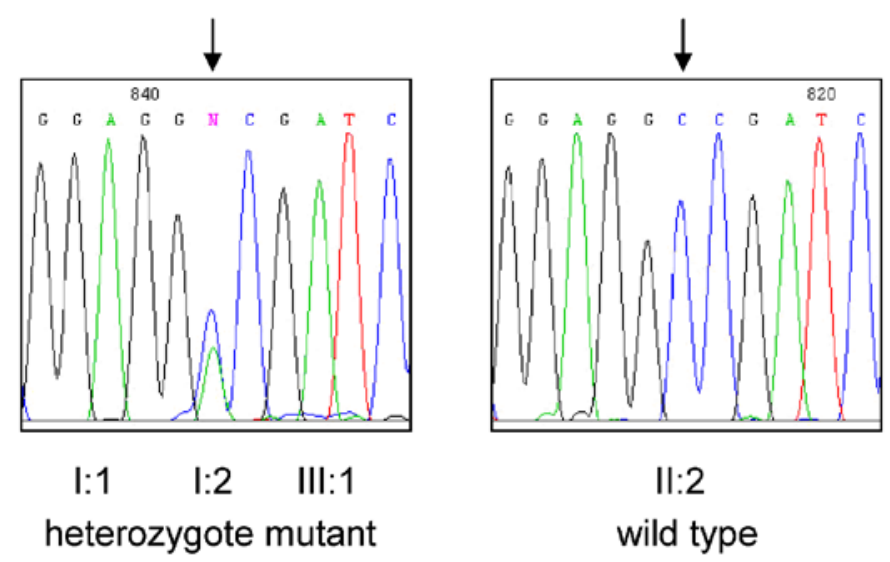

C

$\begin{array}{ccc}47 & 48 & 49 \\ \text { Arg } & \text { Pro } & \text { lle } \\ \text { AGG } & \text { CCG } & \text { ATC } \\ & \downarrow & \\ & \text { ACG } & \\ & \text { Thr } & \end{array}$

Figure 7. Family tree of the multiple primary melanoma patient (a). Detection of the P48T mutation in homozygote form in the patient (II:1) and in heterozygote form in the parents and daughter of the patient (I:1, I:2, III:1) (b-c). 
Analysis of the coding region of the MC1R gene in the family members showed that there are three different well-known MC1R polymorphisms running in the family. The parents and the widow of the patient (individuals I:1, I:2 and II:2) harbour only one polymorphism in heterozygote form: CGC>TGC (R151C), GTG>ATG (V92M) and CGC>CAC (R142H), respectively. The patient and his young daughter, however, are compound heterozygotes and carry two melanoma susceptibility-related MC1R polymorphisms: V92M, R151C and V92M, R142H (Table 2).

\begin{tabular}{|c|c|c|c|c|c|c|}
\hline $\begin{array}{c}\text { Nucleotide } \\
\text { polymorphism }\end{array}$ & $\begin{array}{c}\text { Amino acid } \\
\text { change }\end{array}$ & I:1 & I:2 & II:1 & II:2 & III:1 \\
\hline$\underline{\text { GTG }>\text { A }}$ TG & V92M & GG & GA & GA & GG & GA \\
\hline C GC>CÁC & R142H & GG & GG & GG & GA & GA \\
\hline$\underline{\mathbf{C G C}>\underline{\mathbf{T}} \text { GC }}$ & R151C & CT & CC & CT & CC & CC \\
\hline
\end{tabular}

Table 2. MC1R gene polymorphisms detected in the family harbouring the P48T CDKN2A mutation.

\subsection{Detection of the R24P CDKN2A mutation in association with multiple primary malignancies including melanoma}

The 33-year-old female patient (II/1, melanoma, breast and pancreas carcinoma), her father ( $\mathrm{I} / 2$, gastric and laryngeal carcinoma) and her mother ( $\mathrm{I} / 3$, no malignancy) were investigated (case 2). The father's sister (I/1) had died from breast cancer at a young age several decades earlier, therefore her genetic investigation could not be performed (Figure 8a). Sequence analysis revealed that probands I/2 and II/1 carried a heterozygote missense mutation (G/C) in exon 1A of the CDKN2A gene (Figure 8b), causing an arginine to proline amino acid change in codon 24 (R24P) affecting only the p16 ${ }^{\text {INK4a }}$ transcript variant (Figure 8c).

According to the sequencing data of the BRCA1 and BRCA2 genes, none of the 15 most common BRCA mutations could be detected in the female patient. Having received these data, we did not perform BRCA gene analysis on her father. 
a

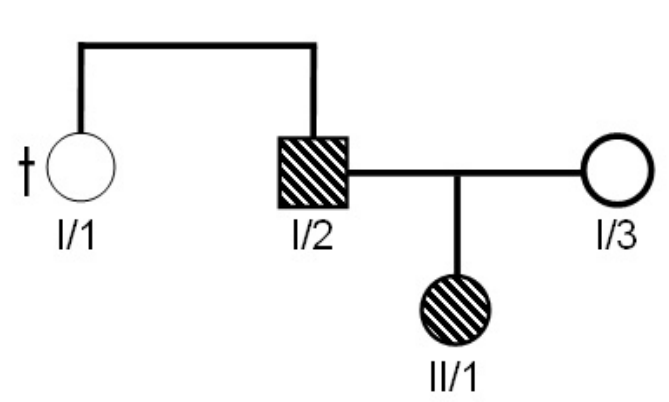

C

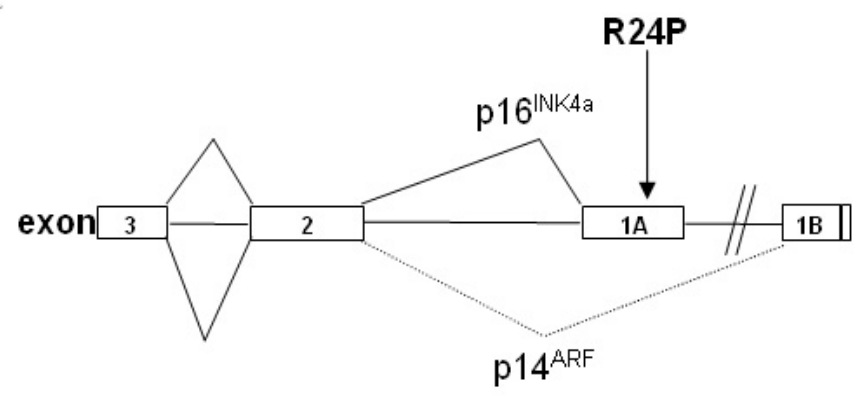

b

$\frac{\text { Patients } I / 2 \text { and } I I / 1}{\text { TC TACC G G ACCCC }}$

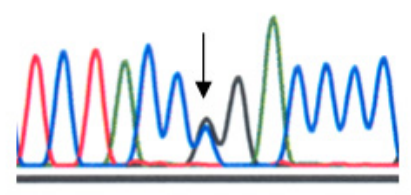

$\mathrm{G} / \mathrm{C}$ heterozygote

CGG $>C \underline{C G}$

Arg $>$ Pro

R24P

Figure 8. Family tree of the patient (II/2) with multiple primary malignancies (a). The patient (II/2) and her father (I/2) carry the R24P CDKN2A mutation in heterozygote form (b). The mutation occurred in exon 1A of the CDKN2A gene (c).

\subsection{Detection of the rare IVS1+37 G/C intronic mutation and its role in splicing regulation}

In case of the family with FAMMM syndrome (case 3), a rare intronic CDKN2A mutation was detected (Figure 9). The mutation is situated in intron 1 (IVS1+37 G/C) and has so far been mentioned twice in case reports: in a FAMMM pedigree and in a single patient with primary melanoma, both from Italy and summarized in a review paper by Orlow et al. ${ }^{29-31}$. In silico assays reported in one of these papers did not reveal any predicted defects in mRNA processing caused by the mutation and it was therefore qualified as a mutation of unknown significance. 
Non-affected family member

A few atypical nevi, not a mutation carrier

No pigmented lesions, an IVS1+37 G/C mutation carrier

Atypical nevi, an IVS1+37 G/C mutation carrier

Melanoma, an IVS1+37 G/C mutation carrier
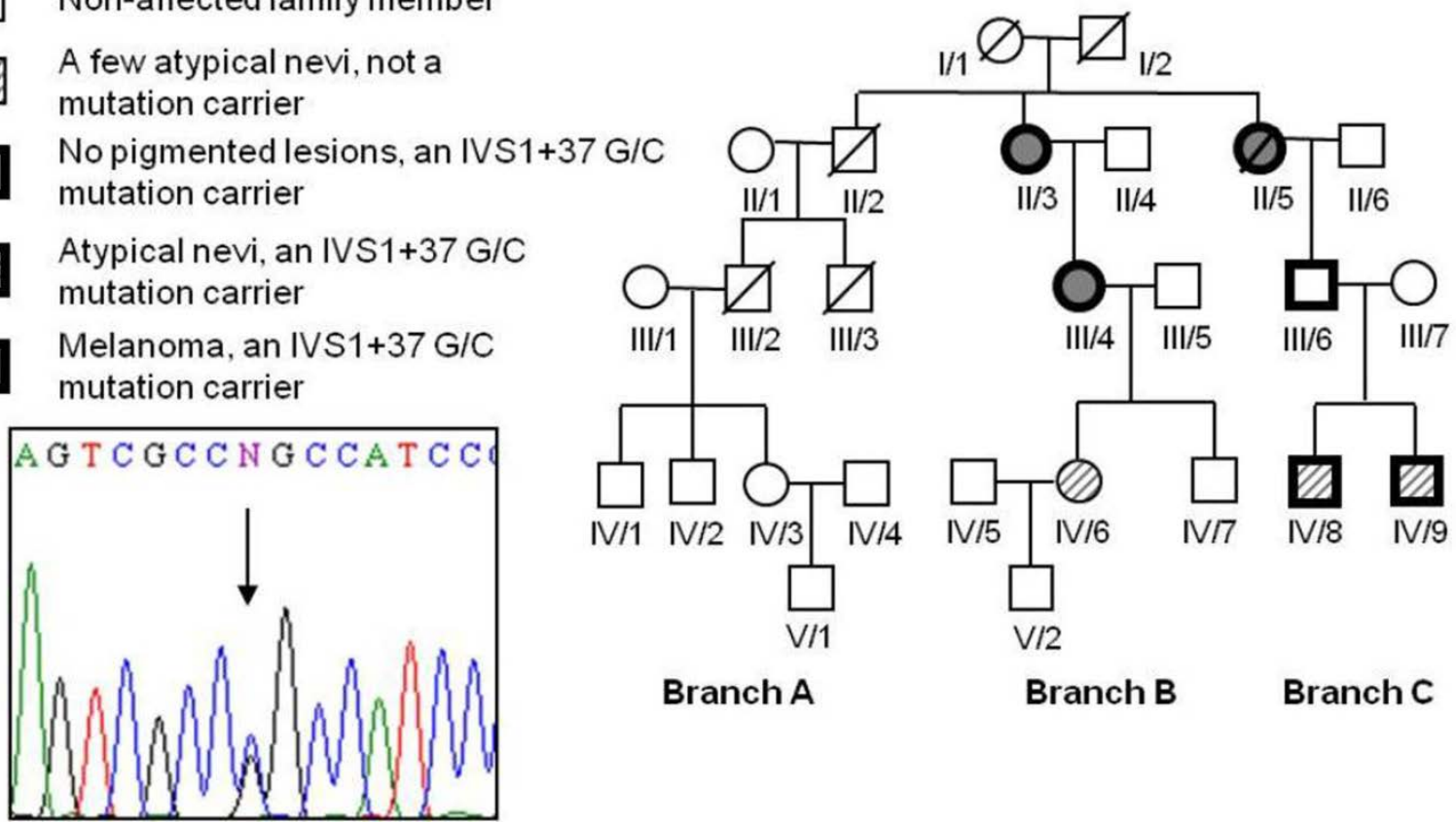

Figure 9. Family tree of the extensive melanoma-prone Hungarian family and detection of the IVS1+37 G/C CDKN2A intronic mutation.

Our sequence analysis involving the comparison of the mRNA arising from the wild-type and that from the mutant minigene revealed a differential splicing pattern (Figure 10b): the shorter band corresponds to a 339-nt CDKN2A sequence as a result of normal splicing, while the 459-nt upper band relates to an extended alternative splice product formed by the addition of a 120-nt sequence of intron 1 as an exon (Figure 10c). This result was identically obtained in three independent transfection experiments on HeLa cells, including work both at the ICGEB and the Department of Dermatology and Allergology laboratories, suggesting that the in vitro minigene approach applied was suitable for studying the effects of the identified intronic IVS1+37 G/C mutation on splicing. 
(a)
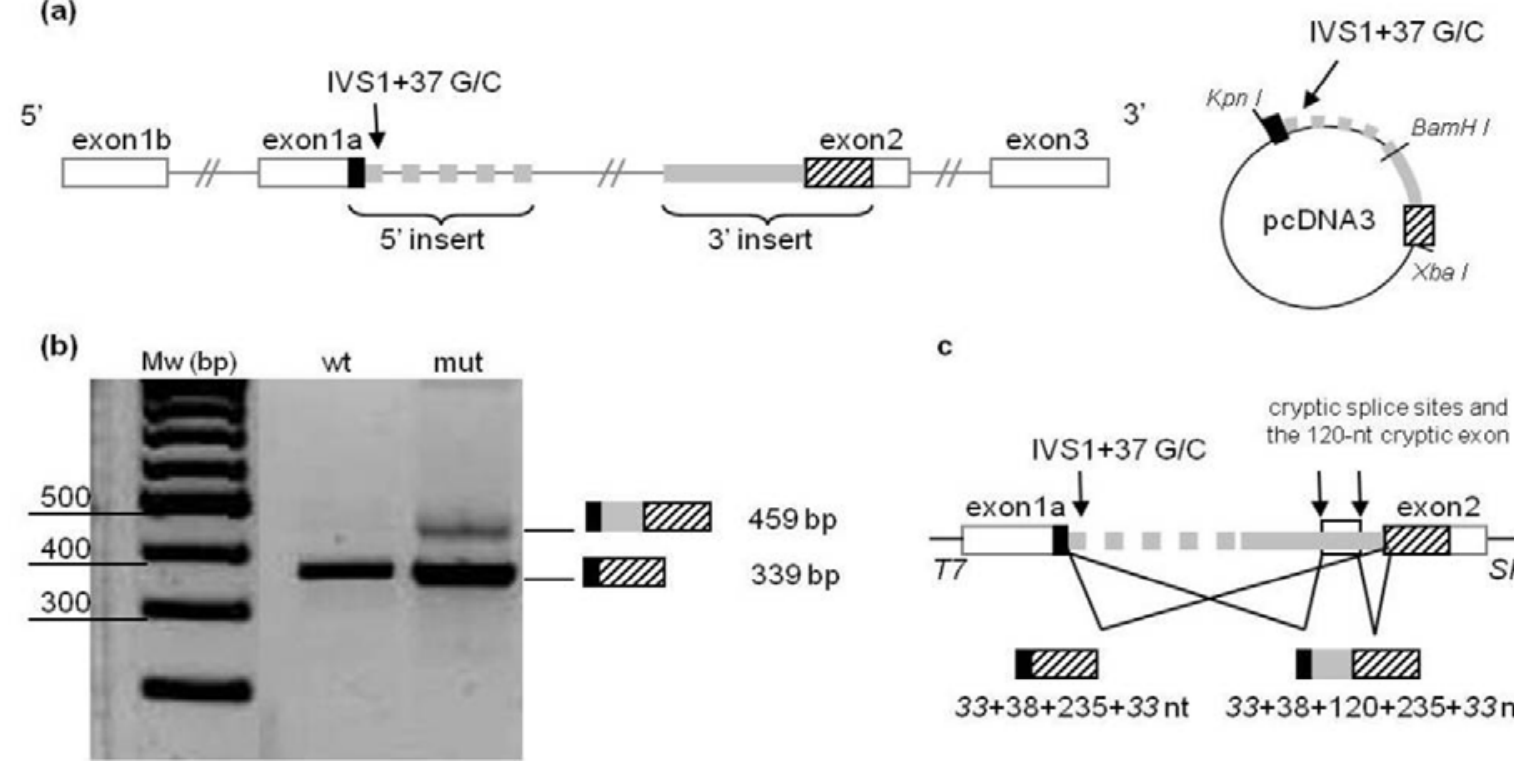

c

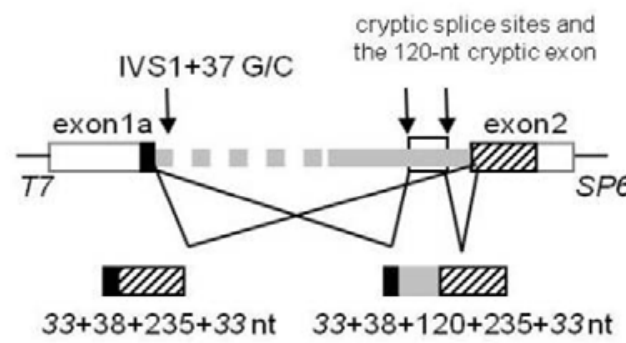

Figure 10. In vitro minigene approach for studying the effects of the IVS1+37 G/C CDKN2A intronic mutation on splicing regulation

In addition to the CDKN2A studies, we also examined the MC1R status of the family members. The results showed that all family members carry at least one frequent MC1R variant. Four family members harbour the frequently detected Val92Met (V92M), so called red hair colour (RHC) variant in heterozygote form. The two most senior individuals examined (II/3, II/5), who developed melanoma carry at least two MC1R variants, including the Arg160Trp (R160W) variant in heterozygote form, which is also a frequent RHC variant. All examined family members carry the common synonymous Thr314Thr variant either in homo- or heterozygote form (Table 3.).

\begin{tabular}{|c|c|c|c|c|c|c|c|c|}
\hline \multicolumn{2}{|c|}{$\begin{array}{l}\text { SNP and } \\
\text { amino acid change }\end{array}$} & $\mathrm{II} / 3$ & $\mathrm{II} / 5$ & $\mathrm{III} / 4$ & III/6 & IV/6 & IV/8 & IV/9 \\
\hline$\underline{\mathbf{G T G}}>\underline{\mathbf{A} T G}$ & V92M & GG & GA & GG & GA & GG & GA & GA \\
\hline 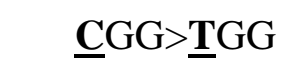 & R160W & CT & CT & CC & CC & CC & CC & CC \\
\hline $\mathrm{AC} \underline{\mathbf{G}}>\mathrm{AC} \underline{\mathbf{A}}$ & T314T & AA & GA & AA & GA & AA & GA & GA \\
\hline
\end{tabular}

Table 3. MC1R polymorphisms detected in the family carrying the IVS1+37 G/C mutation 


\section{DISCUSSION}

Three cases from our cohort of patients and relatives are highlighted in which the detection of CDKN2A mutations was thought to strongly contribute to melanoma susceptibility and possibly contribute to other malignancies.

The CDKN2A gene is known as a major locus for melanoma predisposition. Germline mutations in the CDKN2A gene have been identified in many hereditary melanoma cases and they are associated with the appearance of multiple primary melanomas ${ }^{14,32}$. The gene consists of four coding regions: exons 1A, 1B, 2 and 3. Exons 1A, 2 and 3 code for the $\mathrm{p} 16^{\mathrm{INK} 4 \mathrm{~A}}$ protein, while exons $1 \mathrm{~B}, 2$ and 3 code for $\mathrm{p} 14^{\mathrm{ARF}}$ protein, both inevitable regulators

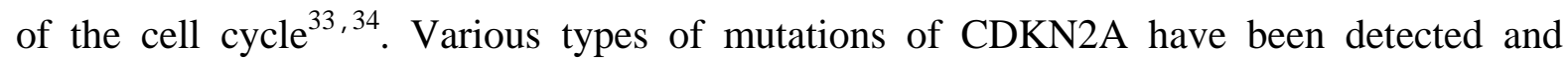
reported in association with different malignancies. Mutations of CDKN2A are listed in the Human Gene Mutation Database ${ }^{35}$. Some of the listed mutations, detected worldwide, have been implicated in melanoma susceptibility and their inheritance has been intensively studied in the affected families ${ }^{36}$, while some CDKN2A mutations have been detected only sporadically and their association with melanoma susceptibility has not been demonstrated in distant ethnic groups.

Most of the so far reported mutations (116 of the 189 so far registered in the Human Gene Mutation Database) are missense or nonsense mutations in the coding regions of the gene and their pathogenetic role in familial and/or multiple primary melanoma has been unquestionably demonstrated in distant ethnic populations. However, in case of a few missense and nonsense CDKN2A mutations ${ }^{37-41}$, the association with melanoma and/or other malignancies has so far been shown only in certain ethnic groups. This is the case with the CDKN2A 142C>A (P48T) transition, which leads to the amino acid change from proline to threonin in codon position 48 (Figure 7c). This rare CDKN2A germline mutation has been reported to date in only four cases. It was first detected in an Italian pancreatic cancer patient ${ }^{37}$, then later in an Italian multiple primary melanoma patient ${ }^{42}$, and in a Brazilian familial melanoma patient with Italian ancestors ${ }^{43}$. Foppiani et al. ${ }^{44}$ detected the P48T mutation in an Italian patient with multiple endocrine neoplasia 2A (MEN 2A) syndrome and papillary thyroid carcinoma along with a RET proto-oncogene mutation. The patient had past history of melanoma and family history of melanoma, pancreatic carcinoma and several other malignancies. 
All four patients mentioned above with Italian ancestry were heterozygous for the P48T mutation. None of the above studies reported genetic studies on family members therefore the possible association of the P48T mutation and the disease phenotype in those cases cannot be discussed. The extensive genetic analysis carried out by Della Torre et al. ${ }^{29}$ on a large melanoma-prone Italian family revealed that the heterozygous carriers of the P48T mutation were susceptible not only to melanoma but also other forms of malignancy. Similarly, disease association of the CDKN2A mutation resulting in the P48L amino acid change at the same position was demonstrated beyond question ${ }^{41}$. The associated family analysis revealed the association of this mutation with a very high susceptibility to various types of cancers, including melanoma.

The presented case suggests that the CDKN2A P48T mutation is highly associated with the appearance of multiple primary melanomas. Our case lends further support to the multifactorial nature of melanoma predisposition, where the penetrance of a certain allele might depend on modifying factors and can be extremely variable across geographic areas ${ }^{45}$, since the heterozygote mutant parents of the patient, at the age of 69 and 63 were free of any malignancies and atypical nevi despite the fact that both have had a rural lifestyle with extensive exposure to sunlight. Furthermore, it is extremely rare to discover individuals homozygous for CDKN2A mutations. These cases therefore offer an opportunity to study the effects of potential human null mutations of this ultimate cell cycle regulatory protein. By studying an endogenous Dutch family with a strong founder effect, Gruis et al. ${ }^{46}$ observed that homozygous carriers of a small deletion in exon 2 of CDKN2A did not appear to be more seriously affected than heterozygous carriers.

Taken together, these results and our present data suggest that CDKN2A mutations in either heterozygous or homozygous form are strong susceptibility factors for various malignancies. The case we presented strongly supports that the rare P48T mutation of CDKN2A is a melanoma-predisposing factor, but our genetic analysis suggests that the heterozygous status itself is not causative of malignant disease. Other modifying factors may be needed for the manifestation of these disorders. The fact that the patient carried two MC1R polymorphisms (V92M, R151C), both of which have been shown to be associated with melanoma and also thought to predispose to non-melanoma skin cancer, independently of the effect on skin type, supports the role of certain MC1R polymorphisms as additional predisposing factors to melanoma. The fact that the daughter of the deceased patient carries both the P48T CDKN2A mutation, as well as two frequently detected, melanoma-associated 
MC1R variants (V92M and R142H), underlines the importance of dermatology follow-up. However, the risk of developing melanoma from carrying these genetic variants can not be quantified accurately.

Although the patient's parents were not aware of consanguinity in their families, the fact that they both harbour the rare 142C>A CDKN2A germline mutation suggests that there must have been such an event or events a few generations ago. It is interesting that the only four previous reports of this mutation, and the one reported after our results were published, involved Italian patients and a Brazilian patient with Italian ancestors. The members of the mentioned Hungarian family are unaware of any Italian family relatives. The question whether this mutation is the result of an independent event or whether the founder mutation migrated some generations ago from Italy to Hungary or from Hungary to Northern Italy demands further investigation.

In contrast with the P48T CDKN2A mutation (which has so far been detected only in Italy and Hungary), the R24P mutation of CDKN2A has been worldwide implicated as a melanoma predisposing genetic factor. The R24P germline mutation was first described by Australian authors. Holland et al. ${ }^{47}$ reported on a survey performed on 17 melanoma-prone families in 1995 and they identified this mutation in one of the studied families. Since then many independent studies proved the melanoma-predisposing nature of this mutation being one of the most widespread among the so far identified disease-associated mutations of the CDKN2A gene. Soon after the first detection, the R24P mutation was also identified in US melanoma-prone families as early as in $1998{ }^{48}$ and its function was also assessed by yeast two-hybrid assay. According to the results, the R24P missense mutation almost completely abrogates the binding activity of the protein, thus explaining the disease-predisposing nature of the mutation. Following the "New World" publications of the R24P mutation, authors also reported it in European melanoma prone families. It was reported in 1998 in the $\mathrm{UK}^{49}$ in the case of a relatively young (31 years old) male patient with multiple primary melanomas and in the case of two unrelated melanoma-prone kindreds in France ${ }^{50}$. This is why review papers from the mid-2000s refer to the R24P mutation as one of the most widespread CDKN2A mutations in the world, contributing to the genetic predisposition to both familial as well as multiple primary melanoma. To our best knowledge, ours is the first report on the identification of the R24P mutation in a Central-European family. Taken together, the above summary well reflects that the R24P CDKN2A mutation is a relatively frequent one all over the world. Whether it is an ancient founder mutation that has spread to many geographical 
locales in the past, or independent mutation events happened, would be interesting to investigate. There have been good examples provided where similar intriguing questions were addressed. Hashemi et al. ${ }^{51}$ demonstrated that the 113insR CDKN2A mutation found only in Southern Scandinavia is a founder mutation that arose approximately 98 generations ago. Similarly, the G101W mutation that is frequent in Northern Italy, Southern Germany and France, is also a founder mutation that arose approximately 97 generations ago ${ }^{52}$. Although the mutations occurred around the same time, the latter has spread worldwide, while the Scandinavian 113insR could not be so far identified in any other geographical locale apart from Sweden. In view of these findings, it would also be very interesting to perform the haplotype mapping of R24P carrier patients to figure out whether it is also a founder mutation and if so, when it occurred in the past.

The idea that CDKN2A mutations may contribute to the predisposition of other primary malignancies beside melanoma came early in the middle of 90's, right after the identification of the gene's role in melanoma predisposition. Monzon et al. ${ }^{48}$ performed epidemiology and genetic studies on multiple primary melanoma cases and melanoma cases associated with multi-organ primary malignancies. They found that about 5 percent of patients have one or more additional primary lesions. This higher-than-expected prevalence of multiple primary melanomas may be due to excessive sun exposure, but according to the authors, genetic factors may also lay behind the phenomena. To support these data, Monzon et al. claimed that patients with multiple primary melanomas very often have a family history of the disease. From epidemiology studies it was already known at the time that approximately 10 percent of melanoma cases have family history of the disease, which suggested genetic predisposition. Moreover, in 20 percent of the familial melanoma cases CDKN2A mutations could also be detected. The authors also claimed that in such families pancreas cancer also has a higher prevalence.

The first in-depth analysis of this topic was reported in $1995^{23}$ by Goldstein and colleagues who compared the prevalence of other tumours in melanoma-prone families harbouring or not harbouring CDKN2A mutations. According to their analysis, CDKN2A mutation-harbouring melanoma-prone families have a 13-fold increased risk to develop pancreas cancer compared to those who do not carry such mutations. There was only one breast cancer patient mentioned in the paper who carried a mutant CDKN2A allele, while no breast cancer case could be detected in the group of melanoma-prone families with wild type CDKN2A alleles. The authors cited previous contrasting data demonstrating that the 
incidence of other types of cancers in melanoma-prone families in the US is not increased ${ }^{53}$. Moreover, another workgroup in the 80's suggested that patients with familial melanoma even had fewer other types of cancers than those suffering from sporadic melanoma ${ }^{54}$. These early data had been overwritten since and it is mainly due to the combined in-depth epidemiological and genetic studies performed within this special group of melanoma patients in the last 20 years. As CDKN2A mutation studies became more and more intensive with the enrolment of centres from all over the world from Australia to the US through Europe, not only the genetic predisposition of familial melanoma but also its co-morbidities became recognised. This is a bright example of how genetic investigations can inspire epidemiological studies and shed light to connections of different diseases and their common predisposing factors. By reviewing several relevant papers we aim to demonstrate the above notion.

As early as 1999, Ghiorzo et al. ${ }^{55}$ reported that the most prevalent melanomapredisposing mutation of the Mediterranean, the G101W, was associated not only with a higher incidence of pancreatic malignancies, but also with breast cancer. In contrast, melanoma-prone families from the same geographical locale without CDKN2A mutations did not exhibit any non-melanoma neoplasias. The authors emphasized that the clinicalepidemiological study was conducted in a small geographical region where the sun and other types of environmental exposures of the individuals were approximately the same, therefore, differences in environmental factors could not account for the different occurrence of disease phenotypes. The authors therefore suggested that determining the underlying CDKN2A mutation in melanoma-prone families may have important implications not only for melanoma but also for further non-melanoma risk assessments.

Here the case of a 33-year-old female patient with the occurrence of three primary multiorgan malignancies was presented. Malignant melanoma, pancreas and breast carcinoma developed independently, within a short period of time. The family history of the patient prompted us to perform a genetic study and we identified the melanoma-predisposing R24P CDKN2A germline mutation in her case as well as in her father, suffering from gastric and laryngeal carcinomas. Since the late aunt of the young female patient died of breast cancer at her twenties several decades ago, we also surveyed the patient for the presence of BRCA1 and BRCA2 hotspot mutations but found no alterations in her case. Although we can not exclude the possibility that other predisposing gene variants may have contributed to the 
breast cancer of the patient, we suggest that the disclosed R24P CDKN2A mutation may have played a key role in the pathogenesis of her multi-organ primary malignancies.

Surveying the relevant literature clearly revealed that CDKN2A germline mutations are highly accepted as predisposing genetic factors for patients who suffer from co-existing pancreas carcinoma and malignant melanoma. However, no such consensus exists for the association of CDKN2A germline variants and the primary multiple occurrence of melanoma and breast cancer. Studies performed in relatively small cohorts of patients resulted in contradictory data: some of them support while others reject the notion of the breast cancerpredisposing nature of CDKN2A germline mutations. To resolve this problem, extended studies on a wide range of low- and high-penetrance genetic predisposing factors must be examined on a multicentre basis. We believe that single cases such as the one we presented here may contribute to the understanding of the role of genetic susceptibility and environmental factors in the pathogenesis of multiple primary malignancies.

With regards to the frequency of melanoma prone families linked to 9p21, the detection of germline coding mutations of the CDKN2A gene is lower than expected. Germline intronic mutations of the CDKN2A gene have also been found in association with melanoma. These were either splice site or deeper intronic mutations. Some of them have been characterized from a functional aspect and their melanoma-predisposing nature has been proved ${ }^{29,30,56-58}$. We detected the IVS1+37 G/C heterozygote intronic mutation of the CDKN2A gene in an extensive Hungarian family with familial atypical multiple mole and melanoma (FAMMM) syndrome. Detailed analysis of the family tree revealed other types of malignancies besides melanoma. The mutation is located at intron 1 (IVS1+37 G/C) considering transcript variants 1 and 4, whereas in case of the pancreas-specific variant, the same nucleotide change theoretically results in a p.Gly63Arg amino acid change in the protein coded by transcript variant 3.

The IVS1+37 G/C mutation has so far been mentioned twice in case reports: in a FAMMM pedigree and in a single primary melanoma patient, both from Italy ${ }^{29,30}$ and summarized in a review paper of Orlow et $\mathrm{al}^{59}$. In silico assays reported in one of these papers did not reveal any predicted defects in mRNA processing caused by the mutation therefore it was categorised as a mutation of unknown significance. However, the fact that the same mutation hypothetically results in an amino acid change in the protein coded by the pancreas-specific transcript variant 3 was not discussed in those papers. 
Our in vitro minigene experiments showed that the presence of the IVS1+37 G/C mutation results in the recognition of an otherwise intronic sequence as an exon and a 120nt long sequence is therefore included in the mRNA. Whether the aberrant mRNA is stable and translated or not, our results indicate that it may play a pathogenetic role in familial melanoma. If the aberrant mRNA was translated, the inclusion of the cryptic exon would result in a frameshift and an early stop codon would change the structure of the p16 protein; if the aberrant mRNA was not stable, it would indirectly reduce the quantity of functional p16. It is interesting that, regarding the pancreas-specific isoform, the mutation theoretically causes a p.Gly63Arg amino acid change. However, mutations in the coding region might also affect splicing regulation ${ }^{57,60}$.

In conclusion, the segregation of the IVS1+37 G/C intronic CDKN2A mutation with FAMMM in the extensive melanoma prone family and the results of our in vitro minigene experiments suggest that this mutation may have a pathogenetic role, most likely involving alteration of the splicing of the CDKN2A primary mRNA. It is important to note that besides CDKN2A coding mutations, intronic mutations of the loci may contribute to melanoma susceptibility. Identification and characterization of these mutations could significantly contribute to our understanding of so far relatively unexplored mechanisms in melanoma pathogenesis and explain why the frequency of germline coding mutations of the CDKN2A gene is lower than expected in melanoma-prone families linked to chromosome 9p21.

Genetic susceptibility to any condition may vary significantly depending on several factors. There are predisposing genes with near $100 \%$ penetrance (everyone with the predisposition will develop the syndrome if they live long enough) for which Huntington chorea is a good example. Other genes have a much lower penetrance depending on environmental or lifestyle factors, as well as the modifying effect of other genes. Melanoma is a typical example of multifactorial diseases. There are well known environmental predisposing factors as well as multiple genes linked to melanoma susceptibility, the effects of which are highly variable on each individual. There have been several studies worldwide investigating the complex genetic networks and environmental modifying factors in the background of melanoma. GenoMEL, the Melanoma Genetic Consortium, is an international research consortium comprised of the majority of research groups worldwide working on the genetics of familial melanoma. The aim of the consortium is better sharing of information and pooling of data. GenoMEL categorises melanoma predisposing genes into rare high penetrance genes such as CDKN2A, and low penetrance genes, MC1R being the most 
common. Melanoma risk in CDKN2A mutation carriers is modified by multiple factors including MC1R variants, pigmentation and nevus phenotype. According to a recent study by Demenais et al., carrying any one of the four most frequent MC1R variants (V60L, V92M, R151C, R160W) in CDKN2A mutation carriers is associated with a statistically significantly increased risk for melanoma across all continents. A consistent pattern of increase in melanoma risk was also associated with increase in number of MC1R variants. The joint analysis of MC1R variants and host phenotypes (hair colour, propensity to sunburn, and number of nevi) showed statistically significant associations of melanoma risk, together with MC1R variants ${ }^{22}$. These joint associations may have important implications in risk assessment of families with multiple cases of melanoma. However, we currently do not have sufficient data to quantify melanoma risk according to these.

Having detected three CDKN2A mutations as detailed out of more than 120 samples analysed, we concluded that CDKN2A mutation detection rates in Hungarian melanomaprone families are comparable to the European and worldwide statistics. The advantage of the proximity of academic resources provides the opportunity to perform genetic analysis. However, in our current practice it is for research purposes only and the results of the analysis and experiments are not directly fed back to our patients. This is partially due to ethical considerations but most importantly because clinical testing for CDKN2A mutations still has a limited role at present in the clinical management. The patients and relatives involved in this study are followed-up closely regardless of their genetic results in our experiments.

The recommendations of the American Academy of Dermatology regarding the selection of patients with familial melanoma for genetic testing are based on a paper of Leachman et al. According to these criteria, for moderate to high melanoma incident areas, individuals with 3 or more primary melanomas and/or families with at least one invasive melanoma and two or more other diagnoses of melanoma and/or pancreatic cancer in aggregate among firstor second-degree relatives on the same side of the family are appropriate candidates for a genetics evaluation. For low melanoma incidence areas, two melanoma and/or pancreatic cancer events in a family may be sufficient to consider a genetics referral. Regardless of whether or not genetic testing is part of the care for families with hereditary melanoma, there is likely benefit from identifying these highest risk families and targeting them for intensive screening and education. They also mention that although not in all cases but the presence of pancreatic cancer in a family with melanoma greatly increases the likelihood of CDKN2A 
mutation detection. Before undergoing genetic testing, patients should be informed of the potential benefits and limitations of testing by a genetic counsellor or other professional with expertise in melanoma genetics ${ }^{61}$.

The Melanoma Genetics Consortium (http://www.genomel.org) ${ }^{62}$ set similar criteria. However, their current consensus is that it is premature to suggest gene testing routinely which may change as more is known of the genes predisposing to melanoma.

The above considerations and our documented cases well demonstrate that genetic testing for research purposes has an important contributory role to science, and potentially to evidence based medicine on the long term. Our cases also underline the standpoint that malignant melanoma even with a highly predisposing genetic background must be considered as a multifactorial disease where the straightforward genetic testing and counselling can not be performed as in the cases of monogenic diseases. This also highlights the importance of multidisciplinary team working between professionals of various specialties, sharing their research, up-to-date evidence based knowledge and experience for a better and holistic patient care. 


\section{SUMMARY}

In the genetic studies we found that CDKN2A mutation detection rates in Hungarian melanoma prone families are low, similarly to international data. Investigations regarding three highlighted CDKN2A mutations were detailed along with the clinical case histories.

The P48T mutation of the CDKN2A gene is a rare mutation and our results suggest that it is indeed a melanoma susceptibility factor but also highlights the variable penetrance of CDKN2A germline mutations. We first detected the P48T mutation in homozygote form which makes it even more interesting in view of the rarity of the mutation. The fact that this mutation has so far been reported in only four cases, all in patients with Italian ancestors, opens questions about whether a founder mutation occurred some generations ago and whether it migrated from Italy to Hungary or vice versa.

The R24P mutation has been world wide implicated as a melanoma predisposing genetic factor. Our genetic studies in the context of the clinical case and the extensive literature review suggest that it is a susceptibility factor not only for melanoma but also for various malignancies possibly including breast cancer.

The segregation of the IVS1+37 G/C intronic mutation with FAMMM syndrome led to an international collaboration which provided benefit to our laboratory by establishing minigene experiments in the investigation of the effect of intronic mutations on splicing. The results of our in vitro analysis suggest that the mutation may have a role in the pathogenesis of melanoma, most likely by altering the mRNA splicing process. It would have been very interesting to compare our in vitro results to that of in vivo experiments had the involved family contributed to our experiments by providing further skin specimens. Nevertheless, we hope that our work will open further research in the investigation of germline intronic mutations of the CDKN2A gene. In addition to CDK2A mutation detection, our results regarding MC1R polymorphisms support the role of genetic interactions in the pathogenesis of melanoma. 


\section{ACKNOWLEDGEMENTS}

This work would not have been possible without the support and help of many people. I would like to show my gratitude to Prof. Dr. Lajos Kemény and Prof. Dr. Attila Dobozy for the opportunity to carry out research work at the Department of Dermatology and Allergology, University of Szeged. I am especially grateful to both my supervisors, Dr.

Judith Oláh and Dr. Márta Széll, who have always been very supportive in many ways despite the geographical distance at times and have been my role models in professional attitude and persistent hard work. I am thankful to Prof. Dr. Franco Pagani for the opportunity to be a part of his team while working in collaboration with the International Centre for Genetic Engineering and Biotechnology in Trieste, Italy with special thanks to Erica Bussani who taught me certain laboratory techniques necessary for my work and who also became a friend. I am obliged to many of my colleagues who contributed to this work, especially Hilda Polyánka and Mónika Kohajda in the laboratory setting and Andrea Gyimesi for the librarian support. I owe sincere thankfulness to my family and my best friend who have been my inspiration and support over the years.

The experimental work of the thesis was supported by the European Union and co-funded by the European Social Fund through the TÁMOP-4.2.2.A-11/1/KONV-2012-0035 European Union Grant. 


\section{7. ÖSSZEFOGLALÁS}

\section{CDKN2A gén mutációk és génkölcsönhatások szerepe a melanoma patogenezisében}

\section{Bevezetés}

A melanoma malignum incidenciája világszerte emelkedő tendenciát mutat. A melanomára hajlamosító tényezők közül jól ismert az UV sugárzás, mint környezeti tényező szerepe. Az alkati tényezők közül legfontosabbak a világos bőrtípus, nagyszámú és/vagy nagyméretű anyajegyek jelenléte. A betegség az esetek mintegy 10\%-ában familiáris jellegü. A klinikai gyakorlatból jól ismert, hogy a familiáris esetek gyakran dysplasticus naevus syndroma talaján, ill. multiplex primer melanomaként jelennek meg, és a sporadikus melanomás esetekhez viszonyítva jóval fiatalabb korban jelentkeznek. Nagy családokon végzett tanulmányok alapján azonosítottak egy „melanoma fogékonysági locust” a 9-es kromoszóma rövid karján (9p21). Bizonyítottá vált, hogy ezen a régión belül a sejtciklust szabályozó cyclin-dependens kináz inhibitor 2A (CDKN2A/p16 $\left.{ }^{\mathrm{INK} 4 \mathrm{~A}}\right)$ gén ivarsejtvonal-beli mutációi játszanak szerepet a familiáris melanoma kialakulásában. A CDKN2A gén mutációinak listája megtalálható a Human Gene Mutation Database honlapján. Némelyik, a weboldalon felsorolt - világszerte elterjedt - mutációt erős melanomára hajlamosító tényezőnek tartják, és az érintett családokban intenzíven tanulmányozták ezek öröklődését, míg más CDKN2A mutációkat eddig elvétve detektáltak, így a melanomával való összefüggésüket nem igazolták nagyobb populáción, ill. eltérő etnikumokban.

A melanocortin-1 receptor (MC1R) gén a normál humán pigmentáció, valamint a bőr napsugárzásra történő reakciójának fő meghatározója. A gén UV sugárzás és melanocortin típusú hormonok (pl. POMC, ACTH) hatására fokozottan fejeződik ki. A gén müködésének eredményeképpen termelődő festékanyag összetételének egyensúlyát számos génvariáció befolyásolja. Általánosságban elmondható, hogy a vad típusú allélt hordozó egyénekben elsősorban eumelanin termelödik. Az eumelanin (fekete/barna pigment) fényvédő hatású, míg a pheomelanin (vörös/sárga pigment) UV hatására szabadgyökök termelődését segíti elő, mely hozzájárulhat a napsugárzás bőrre gyakorolt káros hatásaihoz. A MC1R igen nagy változatosságot mutat, föként a kaukázusi népcsoportokban. Bizonyos variációi vörös hajszínnel, szeplős, nehezen barnuló bőrtípussal hozhatók összefüggésbe, míg mások a bőrszíntől és napégésre való hajlam fokozása nélkül is emelik mind a melanomára, mind 
nem melanoma típusú bőrrákra való hajlamot. A MC1R gén világszerte végzett számos tanulmányban alacsony penetranciájú, melanomára hajlamosító tényezőnek bizonyult, és az egyéb melanomára hajlamosító génekkel - mint pl. a CDKN2A génnel - való kölcsönhatását jelenleg is intenzíven kutatják.

\section{A betegek genetikai vizsgálatba való bevonása és kísérleti módszerek}

A klinika Dermato-Onkológiai részlegének gondozásában álló betegek körében dysplasticus naevus syndroma, familiáris melanoma, multiplex primer melanoma, valamint egyéb daganatok együttes előfordulása, s főként fiatal életkorban való megjelenése a genetikai predispozíció lehetőségére hívta fel figyelmünket, ezért célul tűztük ki annak felderítését, hogy a CDKN2A gén mutációi, illetve genetikai kölcsönhatások szerepet játszhatnak-e a betegség patogenesisében. A betegek és közvetlen hozzátartozóinak genetikai vizsgálatát az SZTE ÁOK Regionális és Intézményi Humán Orvosbiológiai Kutatásetikai Bizottsága engedélyezte.

A vizsgálatba bevont mintegy 120 beteg esetében $2 \mathrm{ml}$ vénás vérből genomi DNS-t izoláltunk, majd a CDKN2A gén négy exonját, valamint kiválasztott esetekben a MC1R gén egyetlen exonját PCR reakcióval felszaporítottuk. A családtagoknál a genomi DNS izolálás vérmintából, illetve szájnyálkahártya kenetből történt. Az amplikonokat a reakció melléktermékeitől való megtisztítás után a Szegedi Biológiai Központban megszekvenáltattuk. A szekvenciák összehasonlítását a BioEdit szoftver segítségével végeztük.

\section{Eredmények, diszkusszió}

Genetikai vizsgálataink eredményei a nemzetközi adatokkal összhangban azt mutatják, hogy a CDKN2A gén mutációinak előfordulása a melanomára hajlamos magyarországi családokban igen ritka. A dolgozatban három magyar családban azonosított CDKN2A mutáció került részletes bemutatásra a hozzájuk kapcsolódó kórtörténet keretében.

A multiplex primer melanomával kezelt fiatal férfi betegünk és családja esetében detektált P48T mutáció a CDKN2A gén ismert, azonban ritka eltérése. Eredményeink támogatják a mutáció melanomára hajlamosító voltát, azonban egyben azt is alátámasztják, hogy az ivarsejtvonal-beli CDKN2A mutációk penetranciája meglehetősen változó. A P48T mutáció homozigóta formában való azonosítása a mutáció eleve ritka voltát tekintve is 
érdekes eredmény. Mivel a mutációról mindeddig csak négy olasz vagy Brazíliában élő olasz származású családban számoltak be, feltételezzük, hogy az alapító mutáció vagy Olaszországban keletkezett és vándorolt valahogyan Magyarországra, vagy hazánkból került az észak-olasz vidékekre, majd onnan tovább Brazíliába is.

Az R24P mutáció világszerte ismert, mint melanomára hajlamosító genetikai tényező. A bemutatott, három egymást követő primer rosszindulatú daganatban (melanoma, emlő ductalis adenocarcinoma és pancreas adenocarcinoma) szenvedő nőbeteg esetéhez kapcsolódóan, a CDKN2A, BRCA1 és BRCA2 géneken végzett vizsgálatok, valamint a szakirodalom alapos áttekintése alapján úgy véljük, ezen mutáció nem csak melanomára, hanem más rosszindulatú folyamatra, többek között emlö daganatra is genetikai fogákonyságot jelenthet.

Egy Szeged környéki familiáris melanomában és dysplasticus naevus syndromában szenvedő család tanulmányozása során egy újabb CDKN2A mutációt azonosítottunk. A gén introni szakaszát érintő ritka IVS1+37 G/C mutáció jellemzése nemzetközi együttmüködéshez vezetett. A mutáció mRNS splicing folyamatra gyakorolt hatásának vizsgálatát de novo elöállított $\mathrm{CDKN} 2 \mathrm{~A}$ minigén segítségével végeztük. In vitro vizsgálataink eredményei azt mutatták, hogy az IVS1+37 G/C mutáció feltehetően szerepet játszik a melanoma patogenezisében, legnagyobb valószínüséggel az mRNS splicing befolyásolása révén. Ezen eredményeink szövetmintákon végzett, in vivo kísérletekkel való megerősítéséhez az érintett család nem járult hozzá, azoban reméljük, hogy eddigi munkánk eredményei új utakat nyitnak az ivarsejtvonal-beli CDKN2A introni mutációk szerepének vizsgálatában.

Génkölcsönhatások tekintetében a MC1R gén polimorfizmusainak vizsgálata során kapott eredményeink támogatják a gén CDKN2A mutációkkal való kölcsönhatásainak szerepét a melanoma patogenezisében. A P48T CDKN2A mutációt hordozó családban három jól ismert MC1R polimorfizmust is azonosítottunk. Betegünk és gyermeke két melanomával asszociált MC1R géneltérést, míg szülei és felesége egyetlen polimorfizmust hordoznak heterozigóta formában. Az IVS1+37 G/C introni CDKN2A mutációt hordozó familiáris melanomára hajlamos családban a MC1R status vizsgálata arra derített fényt, hogy minden családtag hordoz legalább egy gyakori MC1R variánst, ebböl négy családtag hordozza a gén egyik ún. vörös hajszínnel asszociált változatát. Azok az idősebb családtagok, akiknél melanoma alakult ki, legalább kettő MC1R polimorfizmust hordoz 
heterozigóta formában, köztük egy ismert, melanomával gyakran asszociált változatot. Ezen eredmények összhangban állnak azzal a nemzetközi tanulmányokban összegzett megfigyeléssel, miszerint a MC1R vörös hajszínnel ill. melanomával asszociált változatai számának növekedésével gyakrabban fordul elő melanoma a CDKN2A mutációkat is hordozó egyénekben, valamint azzal, hogy a MC1R bizonyos polimorfizmusainak jelenléte befolyással van a melanomával összefüggésbe hozható CDKN2A mutációk penetranciájára.

A dolgozat kitér a genetikai kísérletekhez füződő eredmények klinikai gyakorlatban való alkalmazásának dilemmájára. Az American Academy of Dermatology szakmai ajánlása alapján - a földrajzi terület melanoma incidenciáját tekintetbe véve - adott családban két ill. három melanomás és/vagy pancreas carcinomás megbetegedés előfordulása elegendő lehet ahhoz, hogy a beteg és családtagjainak klinikai genetikushoz - CDKN2A szürés céljából való beutalását megfontoljuk. Ajánlásaik hangsúlyozzák a betegek genetikushoz való beutalása előtti tájékoztatásának fontosságát ezen adatok megismerésének előnyeiről és veszélyeiről. Amerikai kollegáink ezidáig arra az érdekes megfigyelésre jutottak, hogy a genetikussal való találkozás és a CDKN2A szürés teszt eredményeitől függetlenül is elősegíti a betegek melanomával kapcsolatos ismereteinek bővítését és a betegség megelőzésével kapcsolatos viselkedés tudatos kialakítását. Ezzel szemben a GenoMEL Genetikai Konzorcium nem ajánlja a familiáris melanomára hajlamos családok rutinszerü CDKN2A szürését, - ez hazánkban sem bevett gyakorlat - de reményeink szerint ez a közeljövőben változhat, hiszen egyre több adat áll rendelkezésünkre. Bízunk benne, hogy munkánk hozzájárul a familiáris melanoma genetikai hátterének megértéséhez, és hosszú távon betegeink körültekintő és korszerü gondozásához. 


\section{REFERENCES}

1. Data of the National Cancer Registry of Hungary. 2009 update. http://www.honcology.hu/portal/page/portal/OOI/MEDICAL_ATTENDANCE/medi cal_departments/MD_901. 2009.

2. Oláh J. and Korom, I. Melanoma malignum. (Lecture); University of Szeged, Department of Dermatology and Allergology, Academic year 2012/2013.

3. Oláh J., Somlai B. Melanocytaer naevusok. Melanoma malignum. In: Kárpáti S, Kemény L, Remenyik É, eds. Bőrgyógyászat és venerológia. Budapest: Medicina, 2013.

4. Hayward NK. Genetics of melanoma predisposition. Oncogene 2003; 22: 3053-3062.

5. Aitken JF, Green AC, MacLennan R, Youl P et al. The Queensland Familial Melanoma Project: study design and characteristics of participants. Melanoma Res 1996; 6: 155-165.

6. Lynch HT, Frichot BC, Lynch JF. Familial atypical multiple mole-melanoma syndrome. J Med Genet 1978; 15: 352-356.

7. Lynch HT, Brand RE, Hogg D, Deters CA et al. Phenotypic variation in eight extended CDKN2A germline mutation familial atypical multiple mole melanomapancreatic carcinoma-prone families: the familial atypical mole melanoma-pancreatic carcinoma syndrome. Cancer 2002; 94: 84-96.

8. Kang S, Barnhill RL, Mihm MCJ, Sober AJ. Multiple primary cutaneous melanomas. Cancer 1992; 70: 1911-1916.

9. Goldstein AM, Chan M, Harland M, Gillanders EM et al. High-risk melanoma susceptibility genes and pancreatic cancer, neural system tumours, and uveal melanoma across GenoMEL. Cancer Res 2006; 66: 9818-9828.

10. Cancer Syndromes [Internet]. Bethesda: National Center for Biotechnology Information , 2009. 
11. Lin J, Hocker TL, Singh M, Tsao H. Genetics of melanoma predisposition. Br J Dermatol 2008; 159: 286-291.

12. Cannon-Albright LA, Goldgar DE, Meyer LJ, Lewis CM et al. Assignment of a locus for familial melanoma, MLM, to chromosome 9p13-p22. Science 1992; 258: 11481152.

13. Sharpless E, Chin L. The INK4a/ARF locus and melanoma. Oncogene 2003; 22; 3092-3098.

14. Czajkowski R, Placek W, Drewa G, Czajkowska A et al. FAMMM syndrome: pathogenesis and management. Dermatol Surg 2004; 30: 291-296.

15. Newton Bishop JA, Harland M, Bennett DC, Bataille V et al. Mutation testing in melanoma families: INK4A, CDK4 and INK4D. Br J Cancer 1999; 80: 295-300.

16. Robertson KD, Jones PA. Tissue-specific alternative splicing in the human INK4a/ARF cell cycle regulatory locus. Oncogene 1999; 18: 3810-3820.

17. Structure of the CDKN2A gene. 2013. Catalog

18. Garcia-Borron JC. SOX9 and the tanning response: something new under the sun. Pigment Cell Melanoma Res 2008; 21: 3-4.

19. Law MH, Macgregor S, Hayward NK. Melanoma genetics: recent findings take us beyond well-traveled pathways. J Invest Dermatol 2012; 132: 1763-1774.

20. Valverde P, Healy E, Jackson I, Rees JL et al. Variants of the melanocyte-stimulating hormone receptor gene are associated with red hair and fair skin in humans. Nat Genet 1995; 11: 328-330.

21. Fargnoli MC, Pike K, Pfeiffer RM, Tsang S et al. MC1R variants increase risk of melanomas harbouring BRAF mutations. J Invest Dermatol 2008; 128: 2485-2490.

22. Demenais F, Mohamdi H, Chaudru V, Goldstein AM et al. Association of MC1R variants and host phenotypes with melanoma risk in CDKN2A mutation carriers: a GenoMEL study. J Natl Cancer Inst 2010; 102: 1568-1583. 
23. Goldstein AM, Fraser MC, Struewing JP, Hussussian CJ et al. Increased risk of pancreatic cancer in melanoma-prone kindreds with p16INK4 mutations. $N$ Engl $J$ Med 1995; 333: 970-974.

24. Fargnoli MC, Gandini S, Peris K, Maisonneuve P et al. MC1R variants increase melanoma risk in families with CDKN2A mutations: a meta-analysis. Eur J Cancer 2010; 46: 1413-1420.

25. Fargnoli MC, Chimenti S, Keller G, Soyer HP et al. CDKN2a/p16INK4a mutations and lack of p19ARF involvement in familial melanoma kindreds. J Invest Dermatol 1998; 111: 1202-1206.

26. Kennedy C, ter Huurne J, Berkhout M, Gruis N et al. Melanocortin 1 receptor (MC1R) gene variants are associated with an increased risk for cutaneous melanoma which is largely independent of skin type and hair colour. J Invest Dermatol 2001; 117: 294-300.

27. Mitra D, Luo X, Morgan A, Wang $\mathrm{J}$ et al. An ultraviolet-radiation-independent pathway to melanoma carcinogenesis in the red hair/fair skin background. Nature 2012; 491: 449-453.

28. Szell M, Baltas E, Bodai L, Bata-Csorgo Z et al. The Arg160Trp allele of melanocortin-1 receptor gene might protect against vitiligo. Photochem Photobiol 2008; 84: 565-571.

29. Della TG, Pasini B, Frigerio S, Donghi R et al. CDKN2A and CDK4 mutation analysis in Italian melanoma-prone families: functional characterization of a novel CDKN2A germline mutation. Br J Cancer 2001; 85: 836-844.

30. Pastorino L, Bonelli L, Ghiorzo P, Queirolo P et al. CDKN2A mutations and MC1R variants in Italian patients with single or multiple primary melanoma. Pigment Cell Melanoma Res 2008; 21: 700-709.

31. Orlow I, Begg CB, Cotignola J, Roy $\mathrm{P}$ et al. CDKN2A germline mutations in individuals with cutaneous malignant melanoma. J Invest Dermatol 2007; 127: 12341243. 
32. Bartal AH, Cohen Y, Robinson E. Malignant melanoma arising at tattoo sites used for radiotherapy field marking. Br J Radiol 1980; 53: 913-914.

33. Brotherton DH, Dhanaraj V, Wick S, Brizuela L et al. Crystal structure of the complex of the cyclin D-dependent kinase Cdk6 bound to the cell-cycle inhibitor p19INK4d. Nature 1998; 395: 244-250.

34. Ruas M, Peters G. The p16INK4a/CDKN2A tumour suppressor and its relatives. Biochim Biophys Acta 1998; 1378: F115-F177.

35. Human Gene Mutation Database (HGMD® Professional) . http://www.hgmd.cf.ac.uk . 2013.

36. Eliason MJ, Larson AA, Florell SR, Zone JJ et al. Population-based prevalence of CDKN2A mutations in Utah melanoma families. J Invest Dermatol 2006; 126: 660666.

37. Moore PS, Zamboni G, Falconi M, Bassi C et al. A novel germline mutation, P48T, in the CDKN2A/p16 gene in a patient with pancreatic carcinoma. Hum Mutat 2000; 16: 447-448.

38. Soufir N, Lacapere JJ, Bertrand G, Matichard E et al. Germline mutations of the INK4a-ARF gene in patients with suspected genetic predisposition to melanoma. $\mathrm{Br}$ J Cancer 2004; 90: 503-509.

39. Borg A, Sandberg T, Nilsson K, Johannsson O et al. High frequency of multiple melanomas and breast and pancreas carcinomas in CDKN2A mutation-positive melanoma families. J Natl Cancer Inst 2000; 92: 1260-1266.

40. Levanat S, Situm M, Crnic I, Marasovic D et al. Alterations in CDKN2A locus as potential indicator of melanoma predisposition in relatives of non-familial melanoma cases. Croat Med J 2003; 44: 418-424.

41. Levanat S, Situm M, Crnic I, Marasovic D et al. Alterations in CDKN2A locus as potential indicator of melanoma predisposition in relatives of non-familial melanoma cases. Croat Med J 2003; 44: 418-424. 
42. Mantelli M, Pastorino L, Ghiorzo P, Barile M et al. Early onset may predict G101W CDKN2A founder mutation carrier status in Ligurian melanoma patients. Melanoma Res 2004; 14: 443-448.

43. Huber J, Ramos ES. The P48T germline mutation and polymorphism in the CDKN2A gene of patients with melanoma. Braz J Med Biol Res 2006; 39: 237-241.

44. Foppiani L, Forzano F, Ceccherini I, Bruno W et al. Uncommon association of germline mutations of RET proto-oncogene and CDKN2A gene. Eur J Endocrinol 2008; 158: 417-422.

45. Bishop DT, Demenais F, Goldstein AM, Bergman W et al. Geographical variation in the penetrance of CDKN2A mutations for melanoma. J Natl Cancer Inst 2002; 94: 894-903.

46. Gruis NA, van der Velden PA, Sandkuijl LA, Prins DE et al. Homozygotes for CDKN2 (p16) germline mutation in Dutch familial melanoma kindreds. Nat Genet 1995; 10: 351-353.

47. Holland EA, Beaton SC, Becker TM, Grulet OM et al. Analysis of the p16 gene, CDKN2, in 17 Australian melanoma kindreds. Oncogene 1995; 11: 2289-2294.

48. Monzon J, Liu L, Brill H, Goldstein AM et al. CDKN2A mutations in multiple primary melanomas. $N$ Engl J Med 1998; 338: 879-887.

49. MacKie RM, Andrew N, Lanyon WG, Connor JM. CDKN2A germline mutations in U.K. patients with familial melanoma and multiple primary melanomas. J Invest Dermatol 1998; 111: 269-272.

50. Soufir N, Avril MF, Chompret A, Demenais F et al. Prevalence of p16 and CDK4 germline mutations in 48 melanoma-prone families in France. The French Familial Melanoma Study Group. Hum Mol Genet 1998; 7: 209-216.

51. Hashemi J, Bendahl PO, Sandberg T, Platz A et al. Haplotype analysis and age estimation of the 113insR CDKN2A founder mutation in Swedish melanoma families. Genes Chromosomes Cancer 2001; 31: 107-116. 
52. Ciotti P, Struewing JP, Mantelli M, Chompret A et al. A single genetic origin for the G101W CDKN2A mutation in 20 melanoma-prone families. Am J Hum Genet 2000; 67: 311-319.

53. Bohn OL, Fuertes-Camilo M, Navarro L, Saldivar J et al. p16INK4a expression in basal-like breast carcinoma. Int J Clin Exp Pathol 2010; 3: 600-607.

54. Kopf AW, Hellman LJ, Rogers GS, Gross DF et al. Familial malignant melanoma. JAMA 1986; 256: 1915-1919.

55. Ghiorzo P, Ciotti P, Mantelli M, Heouaine A et al. Characterization of ligurian melanoma families and risk of occurrence of other neoplasia. Int J Cancer 1999; 83: 441-448.

56. Majore S, Catricala C, Binni F, De Simone P et al. CDKN2A: the IVS2-105A/G intronic mutation found in an Italian patient affected by eight primary melanomas. $J$ Invest Dermatol 2004; 122: 450-451.

57. Loo JC, Liu L, Hao A, Gao L et al. Germline splicing mutations of CDKN2A predispose to melanoma. Oncogene 2003; 22: 6387-6394.

58. Harland M, Mistry S, Bishop DT, Bishop JA. A deep intronic mutation in CDKN2A is associated with disease in a subset of melanoma pedigrees. Hum Mol Genet 2001; 10: $2679-2686$.

59. Gruson LM, Chang MW. Berloque dermatitis mimicking child abuse. Arch Pediatr Adolesc Med 2002; 156: 1091-1093.

60. Pagani F, Baralle FE. Genomic variants in exons and introns: identifying the splicing spoilers. Nat Rev Genet 2004; 5: 389-396.

61. Leachman SA, Carucci J, Kohlmann W, Banks KC et al. Selection criteria for genetic assessment of patients with familial melanoma. J Am Acad Dermatol 2009; 61: 67714.

62. Melanoma Genetics Consortium. http://www.genomel.org. 2013. 
]$_{0}$ 


\section{First detection of the melanoma-predisposing proline-48-threonine mutation of p16 in Hungarians: was there a common founder either in Italy or in Hungary? Márta Széll ${ }^{a, *}$, Klára Balogh ${ }^{\mathrm{b}, *}$, Attila Dobozy ${ }^{\mathrm{a}, \mathrm{b}}$, Lajos Kemény ${ }^{\mathrm{a}, \mathrm{b}}$ and Judit Oláh ${ }^{\mathrm{b}}$}

The P48T germ line mutation of p16 was detected in a Hungarian multiple primary melanoma patient (deceased at the age of 39 ) with no affected family members. Genetic analysis of the patient and his family revealed that the patient was homozygous for the mutation, whereas his parents (father currently aged 69 and mother 63 ), who are free from any malignancies and atypical moles, are both heterozygous for the mutation. Our data suggest that the P48T mutation of p16 is a strong melanoma-predisposing factor, but the fact that the heterozygous mutant parents have not yet exhibited melanoma or atypical moles indicates that the penetrance of this allele might depend on modifying factors. The rare P48T germ line mutation of p16 has been reported previously in only four independent studies, all in patients with Italian ancestry. Here, we first report the inheritance of the rare $\mathrm{P} 48 \mathrm{~T}$ mutation of CDKN2A in a Hungarian family with a homozygous multiple primary melanoma member and unaffected heterozygous family members. The question of whether the mutation

\section{Introduction}

The incidence of cutaneous malignant melanoma is increasing worldwide and familial cutaneous melanoma accounts for approximately $10 \%$ of melanoma cases [1]. It is well known from dermatological practice that familial melanoma frequently presents with multiple primary melanomas and clinically atypical moles, and is diagnosed at a much younger age than sporadic cutaneous melanoma [2]. Genetic linkage analysis in large melanoma kindreds identified a melanoma susceptibility locus on human chromosome 9p21 [3], germ line mutations of the cyclindependent kinase inhibitor 2a (CDKN2A/p16INK4A) gene within this chromosomal region are responsible for melanoma susceptibility [4,5]. Mutations of CDKN2A are listed in the Human Gene Mutation Database, http:// wwr.hgmd.cf.ac.uk (accessed 15 August 2006). Some of the listed mutations, detected worldwide, have been implicated in melanoma susceptibility and their inheritance has been intensively studied in the affected families [6], whereas some CDKN2A mutations have been detected only sporadically, and their association with melanoma susceptibility has not been demonstrated in distant ethnic groups. This applies to the P48T mutation of CDKN2A which has so far been detected in only one Italian pancreas carcinoma patient [7], one Italian [8] and detected in Hungary is the result of an independent event, or migration of the founder mutation occurred at some time in the past, necessitates further investigations. Melanoma Res 17:251-254 @ 2007 Lippincott Williams \& Wilkins.

Melanoma Research 2007, 17:251-254

Keywords: CDKN2A gene, germ line mutation, multiple primary melanoma, p16 protein

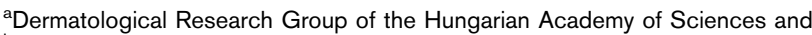
${ }^{b}$ Department of Dermatology and Allergology, University of Szeged, Hungary

Correspondence to Dr Márta Széll, PhD, Dermatological Research Group of the Hungarian Academy of Sciences, University of Szeged, H-6720 Szeged, Korányi fasor 6 , Hungary

Tel: + 3662 545278; fax: + 3662545954 ;

e-mail: szell@mail.derma.szote.u-szeged.hu

*Márta Széll and Klára Balogh have contributed equally to this work.

Received 13 October 2006 Accepted 24 March 2007

one Brazilian [9] melanoma patient, and has been most extensively studied in a large Italian melanoma-prone family [10]. Here, we report the inheritance of the rare P48T mutation of CDKN2A in a Hungarian family with a homozygous multiple primary melanoma member and unaffected heterozygous family members.

\section{Patients and methods}

A 30-year-old Caucasian male presented at our department in 1997 with a thick ulcerated nodular melanoma (pT3b) in the right femoral region (Fig. 1a). He also suffered from a sporadic form of multiple atypical mole syndrome (Fig. 1b and c). At the time of diagnosis of the primary tumor in the right femoral region which was already $2 \mathrm{~cm}$ in size and bleeding, two early primary melanomas were also diagnosed on his trunk (indicated by arrows in Fig. 1b and c). After removal of these three primary melanomas, he underwent delayed elective radical node dissection from his right groin. The lymph node metastases indicated interferon $\alpha 2 b$ therapy, and he was treated with 10 million units $/ 3$ tw interferon $\alpha 2 b$ for 3 months. Leucopenia and thrombocytopenia complicated the therapy and the patient refused to continue it. During the 8-year follow-up period, a further five new 
Fig. 1
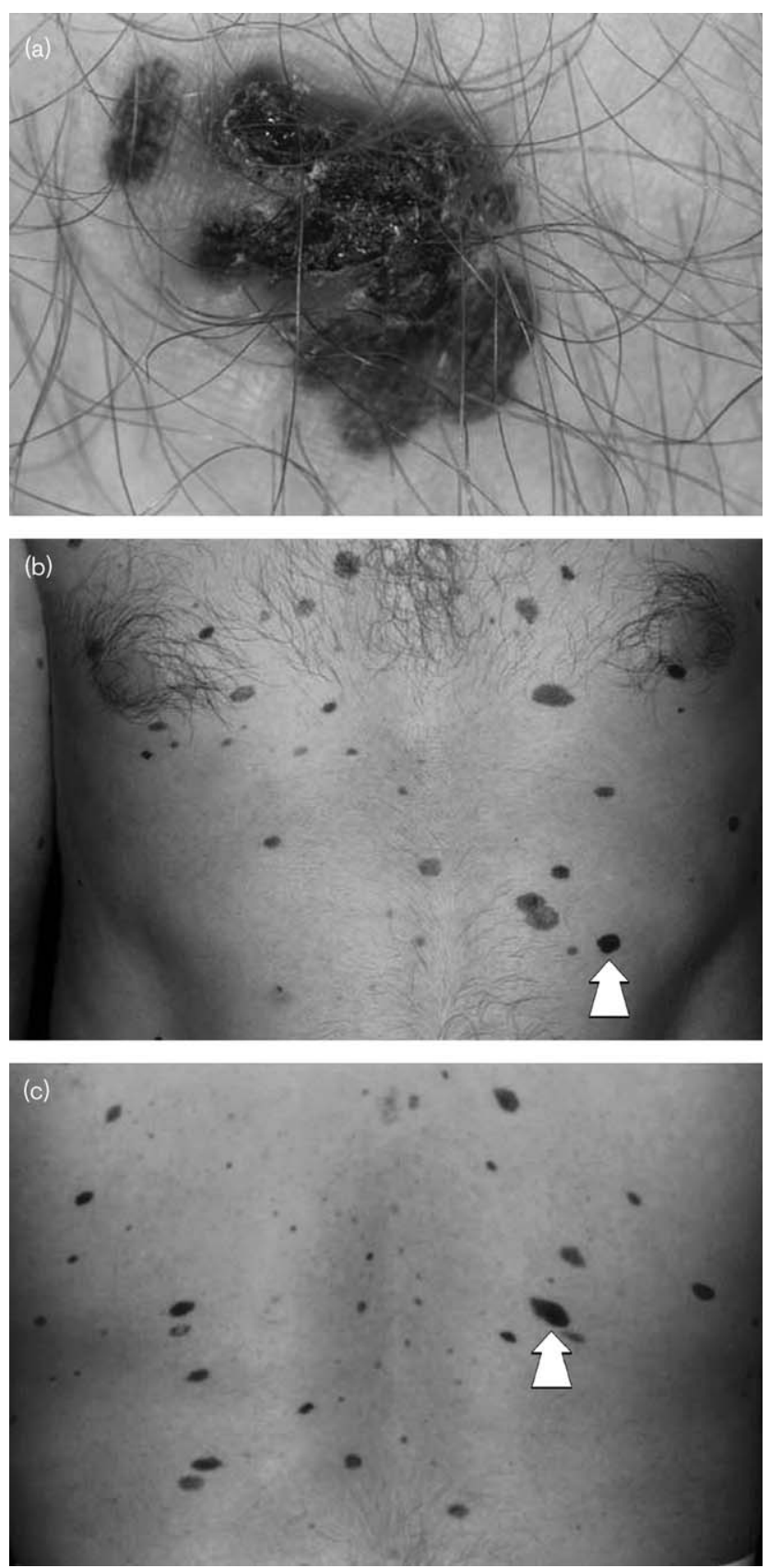

Clinical presentation of the patient. (a) The thick ulcerated nodular melanoma (pT3b) in the right femoral region of the patient at the time of presentation. ( $b$ and $c$ ) The atypical mole syndrome of the patient is apparent on his trunk; the arrows indicate two early primary melanomas diagnosed at the same time as the thick ulcerated nodular melanoma.

early melanomas developed. No internal organ involvement was found for 7 years. In 2004, intra-abdominal lymph node metastases were diagnosed. The patient received bleomycin, vincristine, lomustine and dacarbazine (BOLD) polychemotherapy, which resulted in a slight regression of the metastatic lump. At the end of
2004, radiation therapy was started for the chemoresistant tumor mass in the iliacal and retroperitoneal regions. After irradiation, his condition remained satisfactory for 3 months, with regression of the metastatic lymph nodes. In July 2005, however, intrahepatic metastases were diagnosed. At the end of 2005, he died from multiple symptomatic liver, lung and intracranial metastases.

The appearance of multiple primary melanoma at a relatively young age and the existence of numerous atypical moles suggested a genetic background in this patient, and we therefore decided to investigate the possible involvement of CDKN2A mutations in the pathogenesis. The genetic analysis of the patient and consequently his family members was approved by the local ethics committee. Two millilitres of venous blood was taken, genomic DNA was isolated by using the Genomic DNA Purification Kit of Gentra (Minneapolis, Minnesota, USA), and exons $1 \alpha, 1 \beta, 2$ and 3 of the CDKN2A gene were amplified under the previously reported conditions [11]. The PCR products were purified with the Quantum Prep PCR Kleen Spin Columns of Bio-Rad (Hercules, California, USA). Sequence analysis revealed a homozygote $142 \mathrm{C}>\mathrm{A}$ transversion, which translates the P48T. The mutation is detected in exon $\alpha$, meaning that it affects the fifth amino acid of the second ankyrin repeat of $\mathrm{p} 16$ protein, but the protein sequence of ARF is unaffected.

After detecting this rare mutation in a homozygous form in our patient, we conducted genetic analysis of his parents, his 6-year-old daughter and his wife (Fig. 2a). The father and the mother, currently aged 69 and 63, had no history of any malignant diseases and both are free of any atypical moles. They had no knowledge of consanguinity or the occurrence of familial melanoma among their relatives. Oral sputum samples were taken from the family members and genomic DNA was isolated from the samples with the MagNA Pure Compact system (Roche, Mannheim, Germany). Exon $1 \alpha$ was sequenced with the Resequencing Amplicon probe system (http:// www.ncbi.nlm.nih.gov/genome/probe/reports/probereport), probe ID: RSA001284450.

\section{Results and discussion}

As demonstrated in Fig. 2b, the patient's father, mother and daughter are all heterozygote carriers of the $142 \mathrm{C}>\mathrm{A}$ mutation, and the wife of the patient harbors the wildtype allele. Our results suggest that the patient had inherited one mutant allele from his father and one from his mother, and further transmitted the mutant allele to his daughter.

Germ line mutations in the CDKN2A gene have now been identified in many hereditary melanoma cases, and are associated with the appearance of multiple primary 
Fig. 2

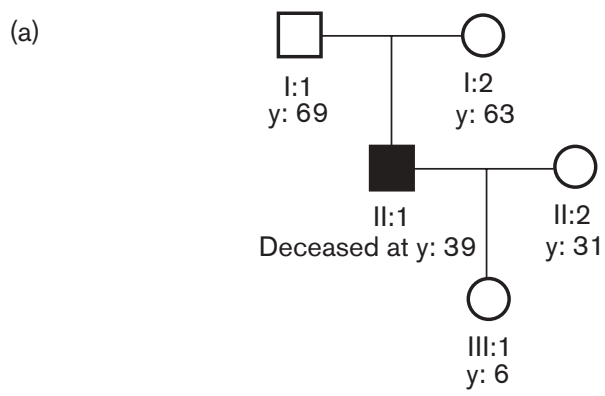

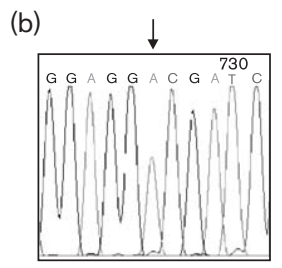

II:1 Homozygote mutant

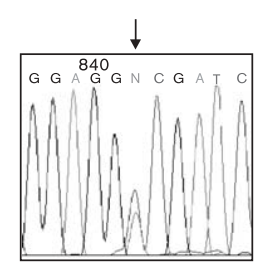

$\mathrm{I}: 1 \quad \mathrm{I}: 2 \quad \mathrm{III}: 1$

Heterozygote mutant

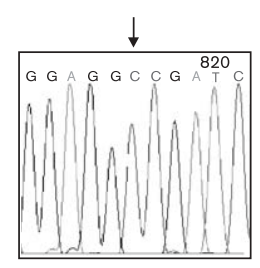

II:2 Wild type (c)

$\begin{array}{ccc}47 & 48 & 49 \\ \text { Arg } & \text { Pro } & \text { lle } \\ \text { AGG } & \text { CCG } & \text { ATC } \\ & \downarrow & \\ & \text { ACG } & \\ & \text { Thr } & \end{array}$

Molecular analysis of the 142C/A CDKN2A variant. (a) The patient (proband) is individual II:1. His father (individual I:1) and mother (individual $\mathrm{l}: 2$ ) are free from malignancies and atypical nevi. (b) Chromatograms showing the $142 \mathrm{C} / \mathrm{A}$ variants; the individuals in the patient's family are listed below the chromatograms according to their genotype. (c) The C/A transversion at nt 142 leads to the Pro/Thr amino acid change in codon position 48 of the p16 transcript.

melanomas $[4,5]$. The gene is composed of four coding regions: exons $1 \alpha, 1 \beta, 2$ and 3 ; exons $1 \alpha, 2$ and 3 code for p16 protein, whereas exons $1 \beta, 2$ and 3 code for ARF protein, both inevitable regulators of the cell cycle $[12,13]$. Various types of mutations are detected on CDKN2A, and their association with different malignant diseases has been documented. Most of the mutations (67 of the 106 so far registered in HGMD; http:// www.hgmd.cf.ac.uk) are missense or nonsense mutations, and their pathogenic role in familial and/or multiple melanoma has been unquestionably demonstrated in distant ethnic populations. For a few missense and nonsense CDKN2A mutations [7,14-16], however, the association with melanoma and/or other malignant diseases has so far been shown only in certain ethnic groups. This is the situation with the transition $142 \mathrm{C}>\mathrm{A}$, which causes the amino acid change $\mathrm{P} / \mathrm{T}$ in codon position 48 (Fig. 2c). This rare CDKN2A germ line mutation has been reported to date in only four cases. It was first detected in an Italian pancreatic cancer patient [7], then in an Italian multiple primary melanoma patient
[8], and subsequently in a Brazilian familial melanoma patient with Italian ancestors [9]: all three patients were heterozygous for the P48T mutation. None of the above studies reported genetic studies on family members, and the possible association of the CDKN2A P48T mutation and the disease phenotype in those cases can therefore not be discussed. The extensive genetic analysis carried out by Della Torre $e t$ al. [10] on a large melanoma-prone Italian family revealed that the heterozygous carriers of the P48T mutation were susceptible not only to melanoma, but also to other forms of malignancies. Similarly, the disease association of the CDKN2A mutation resulting in the $\mathrm{P} 48 \mathrm{~L}$ amino acid change at the same codon was demonstrated beyond question [17]. The associated family analysis clearly revealed the association of this mutation with a very high susceptibility to various types of cancers, including melanoma.

The present case suggests that the CDKN2A P48T mutation is highly associated with the appearance of primary multiple melanoma. Our case lends further support to the multifactorial nature of melanoma predisposition, where the penetrance of a certain allele might depend on modifying factors and can be extremely variable across geographic areas [18], because the heterozygote mutant parents of the patient, at the ages of 69 and 63, are so far free of any malignancies or any atypical nevi, in spite of the fact that both have had a rural lifestyle, with extensive exposure to sunlight. Furthermore, it is extremely rare to discover individuals homozygous for CDKN2A mutations; these cases therefore offer an opportunity to study the effects of potential human null mutations of this ultimate cell cycle regulatory protein. By studying an endogenous Dutch family with a strong founder effect, Gruis et al. [19] observed that homozygous carriers of a small deletion in exon 2 of CDKN2A did not appear to be more seriously affected than heterozygous carriers. Taken together, these results and our present data suggest that CDKN2A mutations in either the heterozygous or the homozygous state are strong susceptibility factors for various malignant diseases, but other additional factors, such as genetic variations of the melanocortin 1 receptor gene in the case of melanoma, are also needed for manifestation of the malignancies.

Although the patient's parents were not aware of consanguinity in their families, the fact that they both harbor the rare $142 \mathrm{C}>\mathrm{A}$ CDKN2A germ line mutation suggests that there must have been such an event or events a few generations previously. It is interesting that the only four previous reports of this mutation involved Italian patients or a Brazilian patient with Italian ancestors. The members of the present Hungarian family are unaware of any Italian family relatives. The question of whether this mutation is the result of an independent event, or whether the founder mutation migrated some 
generations ago from Italy to Hungary, or from Hungary to Northern Italy, demands further examination.

In conclusion, the case we have presented here has confirmed that the rare P48T mutation of p16 is a melanoma-predisposing factor, but our genetic analysis suggests that the heterozygous status itself is not causative of malignant disease: other modifying factors may be needed for the manifestation of these disorders.

\section{Acknowledgements}

The authors thank Mónika Kohajda for her technical assistance. This work was funded by the Grants OTKA NI 62007, GVOP-3.2.1-2004-04-0372/3.0 and ETT531/2006, 500/2006. M.S. is the holder of Bolyai János Research Grant.

\section{References}

1 Hayward NK. Genetics of melanoma predisposition. Oncogene 2003; 22:3053-3062

2 Aitken JF, Green AC, MacLennan R, Youl P, Martin NG. The Queensland Familial Melanoma Project: study design and characteristics of participants. Melanoma Res 1996; 6:155-165.

3 Cannon-Albright LA, Goldgar DE, Meyer L, Lewis CM, Anderson DE, Fountain JW, et al. Assignment of a locus for familial melanoma, MLM, to chromosome 9p13-p22. Science 1992; 258:1148-1152.

4 Sharpless E, Chin L. The INK4a/ARF locus and melanoma. Oncogene 2003; 22: 3092-3098.

5 Czajkowski R, Placek W, Drewa G, Czajkowska A, Uchanska G. FAMMM syndrome: pathogenesis and management. Dermatol Surg 2004; 30: 291-296.

6 Eliason MJ, Larson AA, Florell SR, Zone JJ, Cannon-Albright LA, Samlowski WE, Leachman SA. Population-based prevalence of CDKN2A mutations in Utah melanoma families. J Invest Dermatol 2006; 126:660-666.

7 Moore PS, Zamboni G, Falconi M, Bassi C, Scarpa A. A novel germline mutation, $\mathrm{P} 48 \mathrm{~T}$, in the CDKN2A/p16 gene in a patient with pancreatic carcinoma. Hum Mutat 2000; 16:447-448.
8 Mantelli M, Pastorino L, Ghiorzo P, Barile M, Bruno W, Gargiulo S, et al. Early onset may predict G101W CDKN2A founder mutation carrier status in Ligurian melanoma patients. Melanoma Res 2004; 14:443-448.

9 Huber J, Ramos ES. The P48T germline mutation and polymorphism in the CDKN2A gene of patients with melanoma. Braz J Med Biol Res 2006; 39:237-241.

10 Della Torre G, Pasini B, Frigerio S, Donghi R, Rovini D, Delia D, et al. CDKN2A and CDK4 mutation analysis in Italian melanoma-prone families: functional characterization of a novel CDKN2A germ line mutation. $\mathrm{Br} J$ Cancer 2001; 85:836-844.

11 Fargnoli MC, Chimenti S, Keller G, Soyer HP, Dal PV, Hofler H, Peris K. CDKN2a/p16INK4a mutations and lack of p19ARF involvement in familial melanoma kindreds. J Invest Dermatol 1998; 111:1202-1206.

12 Brotherton DH, Dhanaraj V, Wick S, Brizuela L, Domaille PJ, Volyanik E, et al. Crystal structure of the complex of the cyclin D-dependent kinase Cdk6 bound to the cell-cycle inhibitor p19INK4d. Nature 1998; 395:244-250.

13 Ruas M, Peters G. The p16INK4a/CDKN2A tumor suppressor and its relatives. Biochim Biophys Acta 1998; 1378:F115-F177.

14 Soufir N, Lacapere JJ, Bertrand G, Matichard E, Meziani R, Mirebeau D, et al. Germline mutations of the INK4a-ARF gene in patients with suspected genetic predisposition to melanoma. Br J Cancer 2004; 90:503-509.

15 Borg A, Sandberg T, Nilsson K, Johannsson O, Klinker M, Masback A, et al. High frequency of multiple melanomas and breast and pancreas carcinomas in CDKN2A mutation-positive melanoma families. J Natl Cancer Inst 2000; 92:1260-1266.

16 Levanat S, Situm M, Crnic I, Marasovic D, Puizina-lvic N, Pokupcic N, et al. Alterations in CDKN2A locus as potential indicator of melanoma predisposition in relatives of non-familial melanoma cases. Croat Med J 2003; 44:418-424.

17 Platz A, Hansson J, Mansson-Brahme E, Lagerlof B, Linder S, Lundqvist E, et al. Screening of germline mutations in the CDKN2A and CDKN2B genes in Swedish families with hereditary cutaneous melanoma. J Natl Cancer Inst 1997; 89:697-702.

18 Bishop DT, Demenais F, Goldstein AM, Bergman W, Bishop JN, Bressac-de Paillerets B, et al. Geographical variation in the penetrance of CDKN2A mutations for melanoma. J Natl Cancer Inst 2002; 94:894-903.

19 Gruis NA, van der Velden PA, Sandkuijl LA, Prins DE, Weaver-Feldhaus J, Kamb A, et al. Homozygotes for CDKN2 (p16) germline mutation in Dutch familial melanoma kindreds. Nat Genet 1995; 10:351-353. 


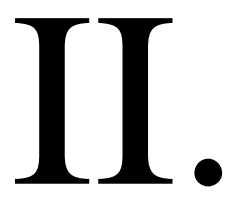




\title{
A CDKN2A gén ritka, ivarsejtvonal-beli mutációja egy multiplex primer melanomában szenvedó betegben és családjában
}

\author{
Rare germ-line mutation of CDKN2A in a Hungarian \\ multiple primary melanoma patient and his family
}

\author{
BALOGH KLÁRA DR. ${ }^{1}$, SZÉLL MÁRTA DR . ${ }^{2}$, DOBOZY ATTILA DR. ${ }^{1,2}$, \\ KEMÉNY LAJOS DR. ${ }^{1,2}$, OLÁH JUDIT DR. ${ }^{1}$
}

\section{ÖSSZEFOGLALÁS}

A CDKN2A prolin-48-treonin aminosavcserét okozó (P48T) ivarsejtvonal-beli mutációját detektáltuk egy multiplex primer melanomában szenvedö (39 éves korában exitált) betegben és tünetmentes családtagjaiban. A család genetikai vizsgálata során kiderült, hogy betegünk homozigóta, míg jelenleg 65 ill. 71 éves szülei-akik sem dysplasticus naevus syndromában, sem melanomában, sem egyéb malignus betegségben nem szenvednek - mindketten heterozigóta formában hordozzák a mutációt. Eredményeink azt sugallják, hogy a CDKN2A gén P48T mutációja erös melanoma predisponáló faktor, azonban az a tény, hogy a heterozigóta mutáns szülóknél mindezidáig nem jelentkezett melanoma vagy dysplasticus naevus syndroma, arra utal, a mutáció penetranciáját egyéb tényezók is nagymértékben befolyásolhatják. A CDKN2A génben bekövetkezö ivarsejtvonal-beli, meglehetôsen ritka P48T mutációt ezidáig négy egymástól független tanulmány tárgyalta; a betegek az esetek mindegyikében olasz ósök leszármazottai. Cikkünk elóször mutatja be ezen ritka, melanomával asszociált mutáció öröklödését magyar családban. Annak megválaszolása, hogy vajon a Magyarországon detektált mutáció független esemény-e, vagy ugyanannak a mutációnak a migrációjáról van szó Olaszországból Magyarországra, vagy esetleg fordítva, további vizsgálatokat igényel.

\section{Kulcsszavak:}

melanoma - dysplasticus naevus

syndroma - CDKN2A gén - p16 fehérje ivarsejtvonal-beli mutáció

\section{SUMMARY}

The P48T germ line mutation of the CDKN2A gene was detected in a Hungarian multiple primary melanoma patient (deceased at the age of 39) with no affected family members. Genetic analysis of the patient and his family revealed that the patient was homozygous for the mutation, while his parents (mother currently aged 65 and father71), who are free from any malignancies and atypical moles, are both heterozygous for the mutation. Our data suggest that the P48T mutation of CDKN2A is a strong melanoma-predisposing factor, but the fact that the heterozygous mutant parents have not yet exhibited melanoma or atypical moles indicates that the penetrance of this allele might depend on modifying factors. The rare P48T germ line mutation of CDKN2A has been reported previously in only four independent studies, all in patients with Italian ancestry. Here we first report the inheritance of the rare P48T mutation of CDKN2A in a Hungarian family with a homozygous multiple primary melanoma member and unaffected heterozygous family members. The question of whether the mutation detected in Hungary is the result of an independent event, or migration of the founder mutation occurred at some time in the past, necessitates further investigations.

Key words: multiple primary melanoma p16 protein - CDKN2A gene germ line mutation
A melanoma malignum incidenciája világszerte emelkedő tendenciát mutat. A betegség az esetek mintegy 10\%-ában familiáris jellegú (1). A klinikai gyakorlatból jól ismert, hogy a familiáris esetek gyakran dysplasticus naevus syndroma talaján ill. multiplex primer melanomaként jelennek meg, és a sporadikus melanomás esetekhez viszo- nyítva jóval fiatalabb korban jelentkeznek (2). Nagy családokon végzett tanulmányok alapján azonosítottak egy „melanoma fogékonysági locust” a 9-es chromosoma rövid karján (9p21) (3). Bizonyítottá vált, hogy ezen a chromosomális régión belül a cyclin-dependens kináz inhibitor 2a (CDKN2A/p16INK4A) gén ivarsejtvonal-beli mu- 
tációi szerepet játszanak a familiáris melanoma kialakulásában (4,5). A CDKN2A gén mutációinak listája megtalálható a Human Gene Mutation Database honlapján (http://www.hgmd.cf.ac.uk). Némelyik, a weboldalon felsorolt - világszerte elterjedt - mutációt erős melanomára hajlamosító tényezőnek tartják, és az érintett családokban intenzíven tanulmányozták ezek öröklődését (6), míg más CDKN2A mutációkat eddig elvétve detektáltak, így a melanomával való összefüggésüket nem igazolták nagyobb populáción ill. eltérő etnikumokban.

A CDKN2A gén prolin-48-treonin aminosav cserét okozó (P48T) mutációját mindezidáig egy olasz pancreas carcinomás (7), egy olasz (8), ill. egy olasz származású brazil (9) melanomás betegben detektálták, és legalaposabban egy melanomára hajlamos olasz nagycsaládban tanulmányozták (10). Cikkünk a CDKN2A gén ezen rendkívül ritka P48T mutációjának öröklődését mutatja be egy magyar családban, amelynek multiplex primer melanomában szenvedő tagja homozigóta formában, malignus betegségtôl megkímélt, vér szerinti hozzátartozói pedig heterozigóta formában hordozzák a mutációt.

\section{Esetismertetés}

1997-ben jelentkezett klinikánkon egy akkor 30 éves, kifejezetten fehér bőrű (Fitzpatrick II) fiatalember a jobb femoralis régióban megjelent, vastag, ulcerált (pT3b), noduláris melanomával (IA áb$r a)$, mely dysplasticus naevus syndroma talaján alakult ki ( $1 B, C$ áb$r a$ ). A jobb femoralis régióban jelentkezô, $2 \mathrm{~cm}$ átmérôjú, kifekélyesedett, vérző primer tumor diagnózisának felállításával egyidejúleg két korai stádiumban felfedezett primer melanomát diagnosztizáltunk (1B, C ábrán nyilakkal jelölve). A három primer tumor eltávolítását követôen betegünk késleltetett electiv jobb inguinalis radicalis blokk dissectión esett át. Az igazolt nyirokcsomó metastasis interferon $\alpha 2 b$ therapiát indokolt, ezért a mûtétet követô 3 hónapon át a beteget heti három alkalommal 10 millió egység interferon $\alpha 2 b$-vel kezeltük. A kezelés mellékhatásaként jelentkező leucopenia és thrombocytopenia miatt a páciens visszautasította a kezelés folytatását. Az ezt követő nyolc éves gondozás és nyomonkövetés során további öt korai primer melanoma került eltávolításra a bőréből. Belszervi érintettség hét éven át nem alakult ki, azonban a szakszerú kezelés ellenére 2004-ben intraabdominalis nyirokcsomó metastasisokat észleltünk. Betegünk emiatt bleomycin, vincristin, lomustin, dacarbazin (BOLD) polychemotherapiában részesült, mely a metastaticus tumor tömeg mérsékelt csökkenését eredményezte. Az iliacalis ill. retroperitonealis elhelyezkedésû chemoresistens tumor massza kezelésére 2004. év végén radiotherapiát indítottunk. Az irradiációt követôen betegünk állapota a metastaticus nyirokcsomó tömeg regressiójának köszönhetően három hónapon át kielégítő maradt, azonban 2005. júliusában intrahepaticus metastasis igazolódott. 2005. végén a fiatal beteg multiplex máj-, tüdő- és intracranialis metastasisok következtében exitált.

\section{Módszer}

A dysplasticus naevus syndroma, valamint a multiplex primer melanoma fiatal életkorban való megjelenése a genetikai predispozíció lehetôségére hívta fel figyelmünket, ezért célul tûztük ki annak felderítését, hogy a CDKN2A gén mutációi szerepet játszhatnak-e a betegség pathogenesisében. A beteg és közvetlen hozzátartozóinak genetikai vizsgálatát az SZTE ÁOK Regionális és Intézményi Humán Orvosbiológiai Kutatásetikai Bizottsága engedélyezte.

A betegtől $2 \mathrm{ml}$ vénás vérből genomi DNS-t izoláltunk (Genomic DNA Purification Kit; Gentra, USA), majd a CDKN2A gén $1 \alpha, 1 \beta$, 2 ill. 3 exonját egy korábbi közleményben (11) leírt PCR reakció körülmények alapján felszaporítottuk. A családtagoknál a genomi DNS izolálás szájnyálkahártya kenetből történt (Magna Pure Compact
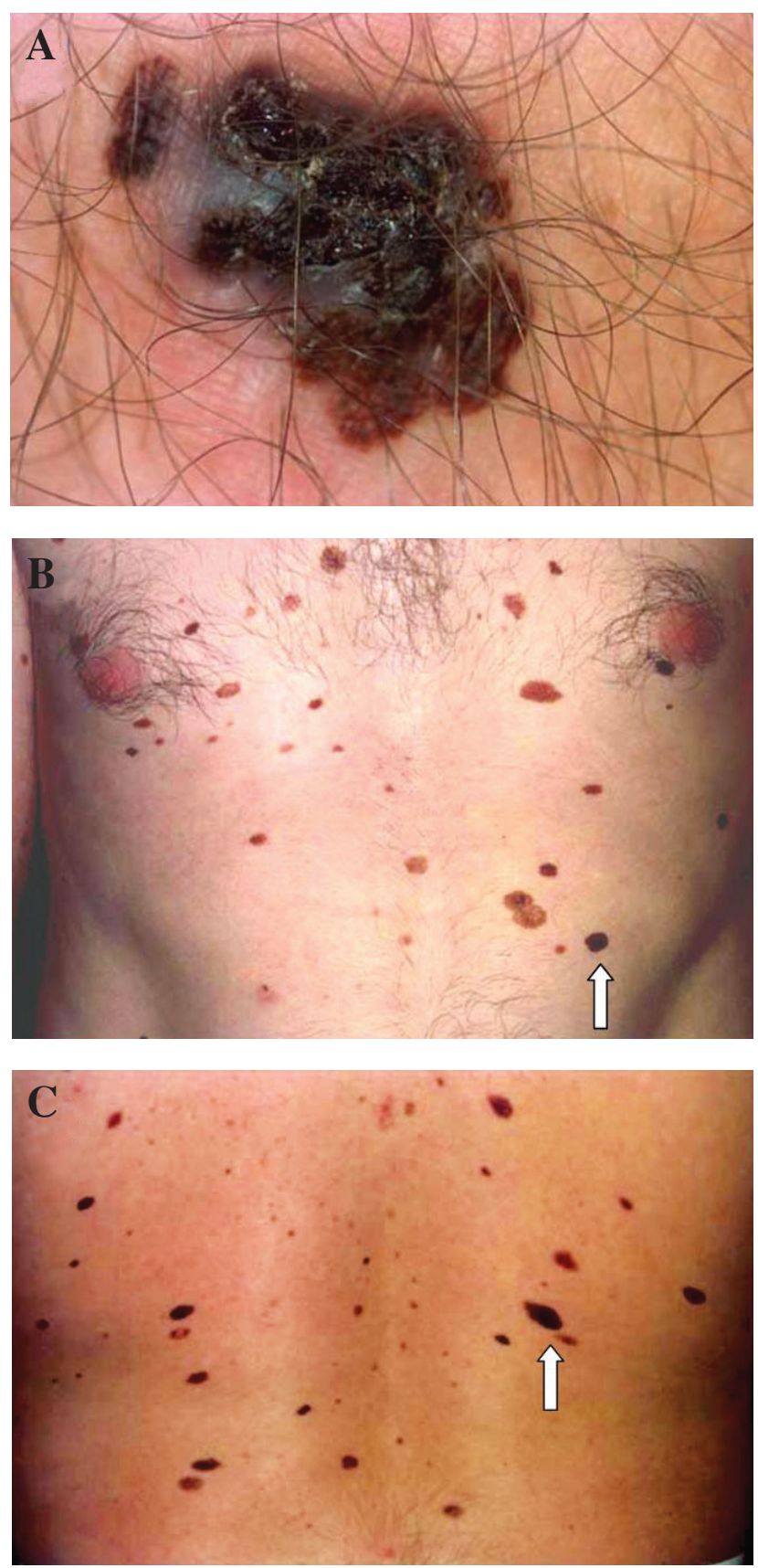

1. ábra

A multiplex primer melanomás beteg klinikai képe A Az első észleléskor diagnosztizált vastag, ulcerált melanoma (pT3b) a jobb femoralis régióban B, C Dysplasticus naevus syndroma a beteg törzsén; a nyilak a femoralis localisatiojú nodularis melanoma diagnózisával egyidőben észlelt két, korai stádiumú primer melanomát jelzik

System; Roche, Németország). A hozzátartozók mintáiból a CDKN2A gén $1 \alpha$ exonját szaporítottuk fel az Interneten elérhetô Resequencing Amplicon Probe rendszer segítségével

(http://www.ncbi.nlm.nih.gov/genome/probe/reports/probereport, probe ID: RSA001284450). Az amplikonokat a reakció melléktermékeitôl való megtisztítás (Quantum Prep PCR Kleen Spin Coloumns; Bio Rad, USA) után a Szegedi Biológiai Központban megszekvenáltattuk. A szekvenciák összehasonlítását a BioEdit szoftver segítségével végeztük

(http://www.mbio.ncsu.edu/BioEdit/BioEdit.html). 


\section{Eredmények}

A szekvencia elemzése során detektáltuk a CDKN2A gén 142. nukleotid pozíciójában a C>A transitiót (142C>A), amely a 48. aminosav pozícióban prolin $>$ treonin $(\mathrm{P} 48 \mathrm{~T})$ aminosav cseréhez vezet. A mutáció a CDKN2A gén $1 \alpha$ exonjában következett be, amely a p16 fehérje második transzmembrán motívumának ötödik aminosavát érinti, azonban az mRNS splicing során - ugyanerről a génről képzôdő - alternatív módon kivágódó p14ARF fehérjében nem okoz eltérést. Miután a ritka P48T mutációt homozigóta formában detektáltuk betegünk mintájában, a beteg szülei, jelenleg 8 éves kislánya és felesége mintáiból is elvégeztük a genetikai vizsgálatot (2A. ábra).

A

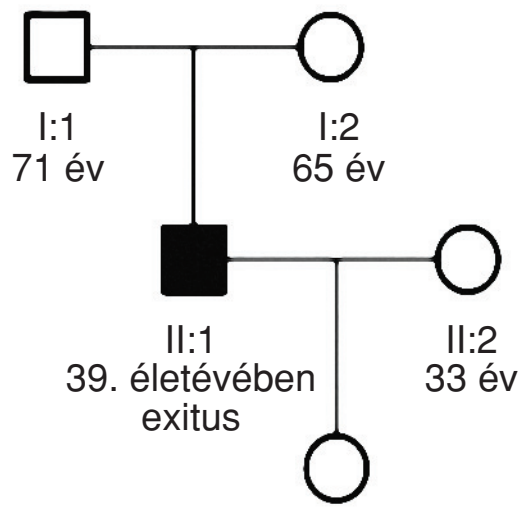

B

III:1

8 év

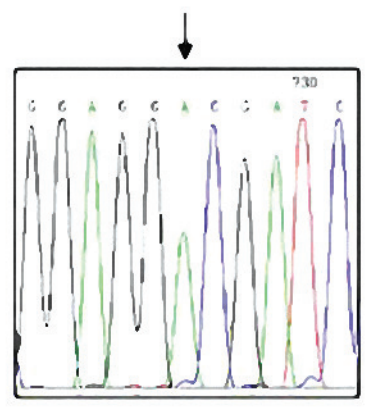

II:1

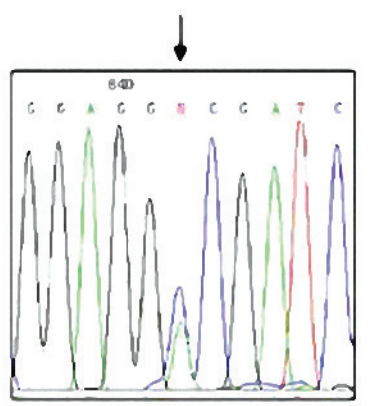

l:1 l:2 III:1 Heterozigóta mutáns

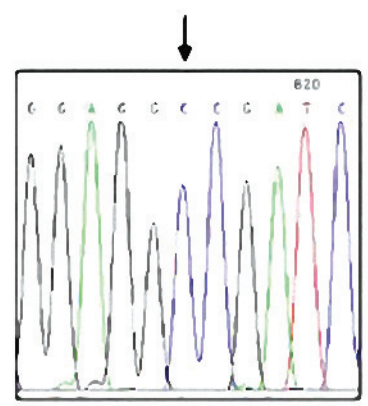

II:2 Vad típus

C

47

48

49

Arg

Pro

Ile

AGG

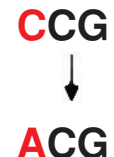

ATC

ACG

Thr

\section{2. ábra}

A CDKN2A 142C >A variáns molekuláris vizsgálata

A A beteg édesanyja (I:2) és édesapja (I:1) esetében nem alakult ki dysplasticus naevus syndroma vagy malignus tumor.

B A chromatogramok a 142C >A mutáció homo-, ill. heterozigóta formáját, valamint a vad típusú allél jelenlétét mutatják be. C A 142C>A transitio a 48. aminosav pozícióban P48T aminosav cserét eredményez. 
Amint a (2B. ábra) mutatja, a beteg édesanyja, édesapja, és kislánya mindannyian heterozigóta formában hordozzák a 142C>A mutációt, míg özvegy felesége a vad típusú allél hordozója. Az eredmények alapján tehát betegünk egy-egy mutáns allélt örökölt szüleitől, majd azt tovább örökítette gyermekébe.

\section{Megbeszélés}

A CDKN2A gén ivarsejtvolnal-beli mutációit számos, családban öröklődő melanomás esetben detektálták, és azokat összefüggésbe hozták multiplex primer melanoma kialakulásával $(4,5)$. A gén négy kódoló egységból épül fel: exon $1 \alpha, 1 \beta, 2$ ill. 3 . Az exon $1 \alpha, 2$ és 3 kódolja a p16 fehérjét, míg az exon1 $\beta, 2$ és 3-ról a p14ARF protein képződik. Mindkét fehérje a sejtciklus szabályozásban tölt be fontos szerepet $(12,13)$. A szakirodalom számos, a CDKN2A génben detektált mutáció, ill. ezeknek különböző malignus betegségekre való hajlam kialakításában betöltött szerepét tárgyalja. A mutációk többsége „,missense” vagy „,nonsense" típusú, és a familiáris ill. multiplex melanoma pathogenezisével való szoros összefüggésük egymástól távoli populációkban is egyértelmúen igazolódott. Bizonyos „missense” ill. „nonsense” típusú CDKN2A mutációk (7,1416) pathogenetikai szerepét melanomával vagy egyéb malignus betegséggel összefüggésben azonban csak néhány egymástól távoli etnikai csoportban írták le.

Ez mondható el a $142 \mathrm{C}>\mathrm{A}$ transitioról is, amely a 48. aminosav pozícióban Pro>Thr aminosav cserét eredményez (2C ábra). Ezt az igen ritka, CDKN2A génben bekövetkező, ivarsejtvonal-beli mutációt mindezidáig 4 esetben írták le. Elsóként egy olasz, pancreas carcinomában szenvedő betegben detektálták (7), majd egy olasz multiplex primer melanomában megbetegedett páciensnél (8), ill. egy olasz származású brazil melanomás betegben (9). Ezek a betegek mindannyian heterozigóta formában hordozták a P48T mutációt. Az említett munkák egyikében sem vizsgálták az egyenes ági rokonok genetikai státusát, ezért ezekben az esetekben a P48T mutáció és a beteg phenotypus összefüggéséról sem lehetett következtetéseket levonni.

Della Torre és mtsai (10) egy nagy, melanomára hajlamos családon végzett, kiterjedt genetikai vizsgálata feltárta, hogy a P48T mutáció hordozói nem kizárólag melanomára, hanem más malignus betegségekre is fogékonyabbak. Az ugyanebben az aminosav pozícióban bekövetkezô, de eltérô nukleotid csere által okozott, P48L mutáció tumoros megbetegedésre hajlamosító voltát ismertette egy svéd munkacsoport (17). A családtagokra is kiterjesztett analízis során kimutatták, hogy a mutáció malignus tumorokra, köztük melanomára is, kifejezett hajlamot eredményez. Egy endogám holland közösség vizsgálata során Gruis és kutatócsoportja (18) a következôt figyelte meg: a CDKN2A gén exon2-ben bekövetkezett kis delécióját (mely nagy valószínúséggel alapító mutáció) homozigóta formában hordozó melanomás családtagoknál nem volt klinikailag észlelhető különbség a betegség súlyosságában a heterozigóta hordozókhoz viszonyítva. Mindent egybevetve, a fenti adatok és jelen eredményeink alapján úgy gondoljuk, hogy a CDKN2A gén mutációi mind homo-, mind heterozigóta formában erős melanoma predisponáló faktorok, azonban egyéb addicionális genetikai eltérések, mint pl. - melanoma estén - a melanocortin-1 receptor gén egyes genetikai variációinak megléte is szükségesek lehetnek a betegség manifesztációjához.

A jelenleg ismertetett magyarországi eset arra enged következtetni, hogy a CDKN2A génben létrejött P48T mutáció szorosan összefügg a multiplex primer melanoma kialakulásával. Esetünk támogatja azt az elméletet is, mely szerint a melanomára való hajlam multifaktoriális természetú: az allélok penetranciája nagyban függ környezeti ill. egyéb genetikai tényezőktől, és földrajzi területenként nagyfokú változatosságot mutat (19). Betegünk heterozigóta mutáns szüleinél (akik jelenleg 65, ill. 71 évesek), máig nem manifesztálódott sem dysplasticus naevus syndroma, sem melanoma, sem egyéb malignus betegség annak ellenére, hogy mezőgazdasággal foglalkoznak, így egész életükben erôs napfény expozíciónak voltak kitéve. A fentieken kívül esetünk amiatt is ritkaságnak számít, mert a CDKN2A gén mutációit homozigóta formában csak elvétve detektálják; ezek az esetek azt teszik lehetővé, hogy tanulmányozhassuk az ebben az alapvető sejtciklus szabályozó génben bekövetkező változások hatását a tumor képződésre.

Habár a beteg szüleinek nincsen tudomása a családban előfordult rokonházasságról, az a tény, hogy a rendkívül ritka P48T CDKN2A mutációt mind a ketten heterozigóta formában hordozzák, arra enged következtetni, hogy generációkkal korábban ez esetleg mégis bekövetkezhetett. Figyelemre méltó az a tény is, hogy ezt a mutációt mindezidáig kizárólag észak-olaszországi ősök leszármazottaiban detektálták. Az érintett magyar család nem ismer olasz származású családtagot. Annak tisztázása, hogy vajon ez a mutáció függetlenül jött-e létre, vagy esetleg alapító mutáció keletkezett generációkkal ezelőtt, amely Észak-Olaszországból hazánkba vándorolt, vagy akár fordítva, további vizsgálatokat igényel.

Összefoglalva, a bemutatott eset megerősítette a rendkívül ritka P48T mutáció melanomára hajlamosító szerepét, azonban azt is kijelenthetjük, hogy a heterozigóta állapot önmagában nem vezet a betegség kialakulásához, hanem egyéb befolyásoló tényezốk is szerepet játszanak annak manifesztációjában.

\section{Köszönetnyilvánítás}

Köszönetet mondunk Kohajda Mónikának a kísérletes munkában való közremúködéséért. Az elvégzett vizsgálatokat a következó pályázatok támogatták: OTKA NI 62007, GVOP-3.2.1-2004-040372/3.0, ETT 500/2006. Dr. Széll Márta Bolyai János Kutatói Ösztöndíj támogatásában részesül.

\section{IRODALOM}

1. Hayward N. K. és mtsai.: Genetics of melanoma predisposition. Oncogene (2003) 22, 3053-3062.

2. Aitken J. F. és mtsai.: The Queensland Familial Melanoma Project: study design and characteristics of participants. Melanoma Res (1996) 6, 155-165. 
3. Cannon-Albright L. A. és mtsai.: Assignment of a locus for familial melanoma, MLM, to chromosome 9p13-p22. Science (1992) 258, 1148-1152.

4. Sharpless E. és mtsai.: The INK4a/ARF locus and melanoma. Oncogene (2003) 22, 3092-3098.

5. Czajkowski R. és mtsai.: FAMMM syndrome: pathogenesis and management. Dermatol Surg (2004) 30, 291-296.

6. Eliason M. J. és mtsai.: Population-based prevalence of CDKN2A mutations in Utah melanoma families. J Invest Dermatol (2006) 126, 660-666.

7. Moore P. S. és mtsai.: A novel germline mutation, P48T, in the CDKN2A/p16 gene in a patient with pancreatic carcinoma. Hum Mutat (2000) 16, 447-448.

8. Mantelli M. és mtsai.: G. Early onset may predict G101W CDKN2A founder mutation carrier status in Ligurian melanoma patients. Melanoma Res (2004) 14, 443-448.

9. Huber J. és mtsai.: The P48T germline mutation and polymorphism in the CDKN2A gene of patients with melanoma. Braz J Med Biol Res (2006) 39, 237-241.

10. Della T. G. és mtsai.: CDKN2A and CDK4 mutation analysis in Italian melanoma-prone families: functional characterization of a novel CDKN2A germ line mutation. Br J Cancer (2001) 85, 836-844.

11. Fargnoli $M$. C. és mtsai.: CDKN2a/p16INK4a mutations and lack of p19ARF involvement in familial melanoma kindreds. J Invest Dermatol (1998) 111, 1202-1206.
12. Brotherton D. H. és mtsai.: Crystal structure of the complex of the cyclin D-dependent kinase Cdk6 bound to the cell-cycle inhibitor p19INK4d. Nature (1998) 395, 244-250.

13. Ruas M. és mtsai.: The p16INK4a/CDKN2A tumor suppressor and its relatives. Biochim Biophys Acta (1998) 1378, F115-F177.

14. Soufir N. és mtsai.: Germline mutations of the INK4a-ARF gene in patients with suspected genetic predisposition to melanoma. Br J Cancer (2004) 90, 503-509.

15. Borg A. és mtsai.: High frequency of multiple melanomas and breast and pancreas carcinomas in CDKN2A mutation-positive melanoma families. J Natl Cancer Inst (2000) 92, 1260-1266.

16. Levanat $S$. és mtsai.: Alterations in CDKN2A locus as potential indicator of melanoma predisposition in relatives of non-familial melanoma cases. Croat Med J (2003) 44, 418-424.

17. Platz A. és mtsai.: Screening of germline mutations in the CDKN2A and CDKN2B genes in Swedish families with hereditary cutaneous melanoma. J Natl Cancer Inst (1997) 89, 697-702.

18. Gruis N. A. és mtsai.: Homozygotes for CDKN2 (p16) germline mutation in Dutch familial melanoma kindreds. Nat Genet (1995) 10, 351-353.

19. Bishop D.T. és mtsai.: Geographical variation in the penetrance of CDKN2A mutations for melanoma. J Natl Cancer Inst (2002) 94, 894-903.

Érkezett: 2008. IV. 7.

Közlésre elfogadva: 2008. V. 5. 


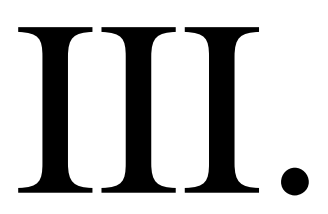




\title{
Detection of a rare $C D K N 2 A$ intronic mutation in a Hungarian melanoma-prone family and its role in splicing regulation
}

\author{
K. Balogh, ${ }^{1}$ M. Széll, ${ }^{2}$ H. Polyánka, ${ }^{2}$ F. Pagani, ${ }^{3}$ E. Bussani, ${ }^{3}$ L. Kemény ${ }^{1,2}$ and J. Oláh ${ }^{1}$ \\ ${ }^{1}$ Department of Dermatology and Allergology, University of Szeged, H-6720 Szeged, Hungary \\ ${ }^{2}$ Dermatological Research Group of the Hungarian Academy of Sciences, University of Szeged, Szeged, Hungary \\ ${ }^{3}$ The International Centre for Genetic Engineering and Biotechnology, Trieste, Italy
}

\section{Summary}

\section{Correspondence \\ Klára Balogh. \\ E-mail: balogh@dermall.hu}

Accepted for publication

24 January 2012

\section{Funding sources}

The work was supported by grants OTKA

K77436, ETT 429-07, TÁMOP-4.2.2-08/

1-2008-0001, T'́MOP-4.2.1/

B-09/1/KONV-2010-0005, TÁMOP-

4.2.2/B-10/1-2010-0012 (Szeged, Hungary)

and TELETHON GGP09183 (Trieste, Italy).

Conflicts of interest

None declared.

DOI 10.1111/j.1365-2133.2012.10864.X
Background The major locus for melanoma predisposition is the cell cycle regulatory CDKN2A gene on chromosome 9p21. However, the frequency of germline coding mutations of the CDKN2A gene is lower than expected in melanoma-prone families linked to chromosome 9p21.

Objectives To investigate whether the rare IVS1+37 G/C intronic mutation of the CDKN2A gene, recently identified in a Hungarian melanoma-prone family, influences mRNA splicing regulation.

Methods CDKN2A minigenes containing the wild-type and the mutant intronic sequence were created and transfected into HeLa cells with the aim of studying the mRNA transcripts.

Results The results revealed the emergence of a differential splicing pattern from the wild-type and the mutant minigene, suggesting that this mutation may alter the splicing of CDKN2A primary mRNA and therefore might have a pathogenetic role in familial melanoma.

Conclusions We believe that these results confirm the importance of the identification and characterization of CDKN2A intronic mutations with a view to improving our understanding of the pathogenesis, and explain why the frequency of germline coding mutations of the CDKN2A gene is lower than expected in melanomaprone families linked to chromosome 9p21.
The major locus for melanoma predisposition is the cell cycle regulatory CDKN2A gene on chromosome 9p21. In the last two decades we have gained much information on the melanomapredisposing coding mutations of the gene; ${ }^{1,2}$ however, we know much less about the role of its intronic mutations. ${ }^{3-7}$ The frequency of germline coding mutations of the CDKN2A gene is lower than expected in melanoma-prone families linked to chromosome 9p21; therefore identification and functional characterization of the intronic variants may provide further insight into the genetic determinants of malignant melanoma.

We report the detection and functional data on the possible pathogenetic role of a rare intronic mutation of the CDKN2A gene found in an extensive Hungarian family with familial melanoma and atypical multiple mole (FAMMM) syndrome.

\section{Patients and methods}

Detailed analysis of the family tree revealed other types of malignancies besides melanoma (Fig. 1). We recently detected the IVS1+37 G/C heterozygote intronic mutation of the CDKN2A gene in the above-mentioned Hungarian melanoma- prone family. Regarding the occurrence of atypical naevi and/or melanoma in nearly all family members carrying the IVS1+37 G/C mutation, along with the family history of manifestation of other malignant tumours, we hypothesized that the mutation may result in aberrant splicing and that the aberrant mRNA may play a pathogenetic role in the development of melanoma. Unfortunately, the members of the melanomaprone Hungarian family declined to provide skin specimens to facilitate the in vivo identification of the alternative CDKN2A splice variants. We therefore conducted in vitro functional analysis to investigate whether the IVS1+37 G/C intronic mutation had any effect on splicing regulation. Two minigenes were constructed: one that harboured the wild-type and one that harboured the mutant allele of CDKN2A (Fig. 2a).

For investigation of the effects of the mutation on splicing, HeLa cells were transfected with the wild-type and mutant minigenes. Transfection was carried out with the TurboFect reagent (Fermentas, Vilnius, Lithuania), the cells were cultured for $24 \mathrm{~h}$ and total RNA was isolated through the use of TRI Reagent Solution (Applied Biosystems, Foster City, CA, U.S.A.). Reverse transcription was performed with the iScript 


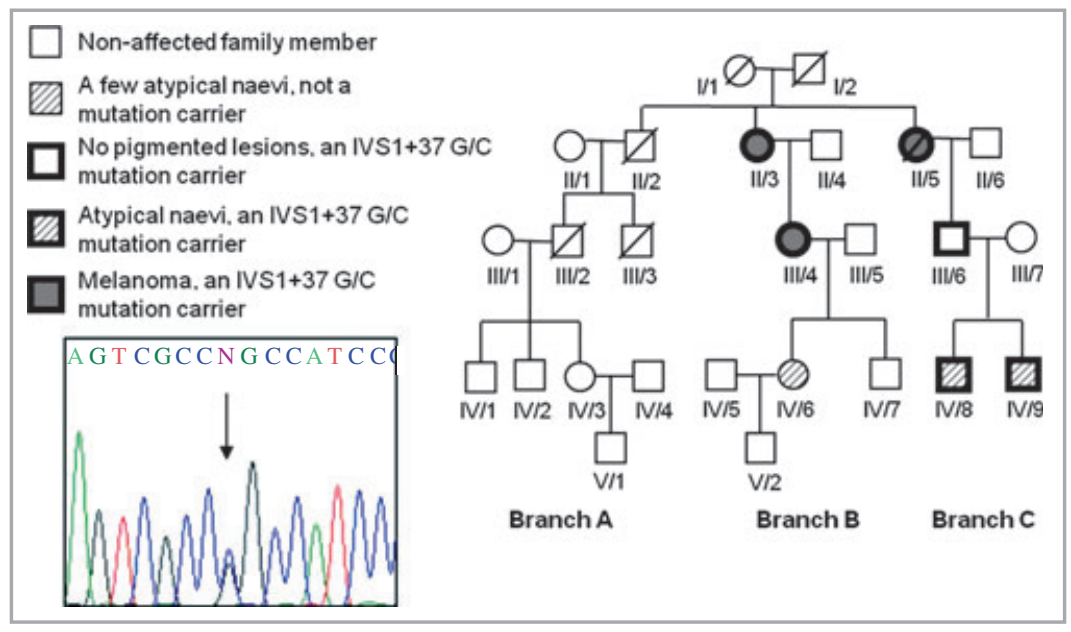

Fig 1. Family tree of the extensive melanomaprone Hungarian family and detection of the IVS1+37 G/C CDKN2A intronic mutation. Direct sequencing of the CDKN2A gene was performed on specimens from seven members of the family (II/3, II/5, III/4, III/6, IV/6, IV/8 and IV/9) in branches B and C. Members in branch A were not available for genetic screening. Most of the family members carrying the IVS1+37 G/C mutation developed atypical naevi and/or melanoma. However, collateral history revealed that of family members of branch $\mathrm{A}$, individual III/2 died from lung carcinoma and individual IV/1 developed prostate carcinoma at a young age.

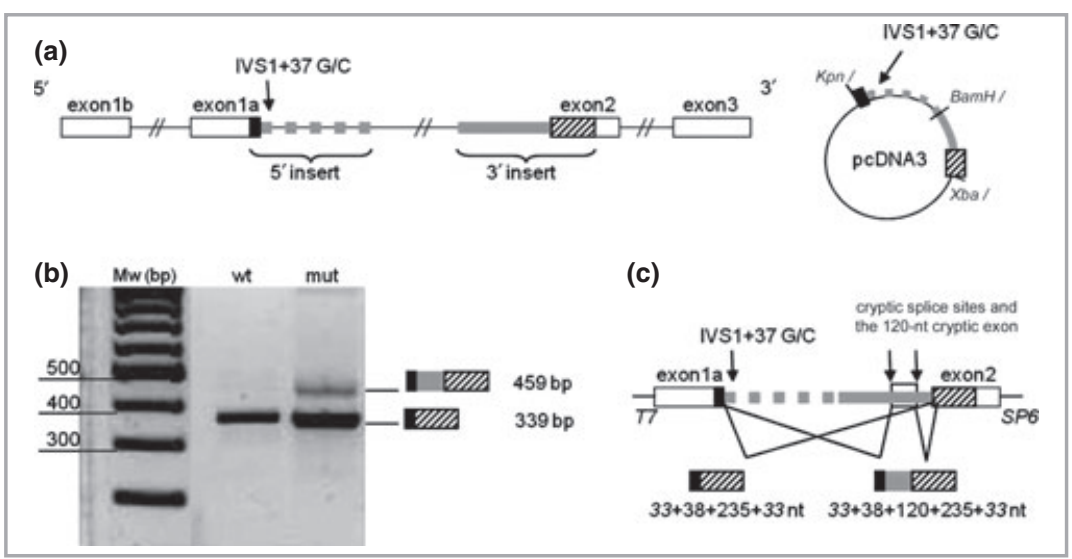

Fig 2. In vitro minigene approach for studying the effects of the IVS1+37 G/C CDKN2A intronic mutation on splicing regulation. (a) Two regions of the CDKN2A gene (Acc. No. AL449423.14; 5' insert: nt 65456-64678 and 3' insert: nt 62359-61715) were amplified from the genomic DNA of patient II/5, who carried the IVS1+37 G/C CDKN2A intronic mutation in a heterozygous form, and were cloned consequently into the pcDNA3 vector (Life Technologies, Carlsbad, CA, U.S.A.). The first insert of the minigene construct included a 38-nt sequence of exon 1a and a 741-nt sequence of the downstream intron (wild-type and mutant versions), while the second insert consisted of a 410 -nt sequence of intron 1 and a 236-nt sequence of exon 2. The entire length of the insert was $1424 \mathrm{nt}$, lacking a 2318-nt deep intronic sequence of the CDKN2A gene (Acc. No. AL449423.14; nt 64677-62360). (b) Reverse transcription-polymerase chain reaction, in which the mRNA arising from the wild-type minigene (wt) was compared with that from the mutant (mut), revealed a differential splicing pattern. (c) Sequence analysis demonstrated that the IVS1+37 G/C mutation resulted in the recognition of cryptic splice sites in intron 1 and thus a 120-nt extension of the mRNA product.

cDNA Synthesis Kit (BioRad, Hercules, CA, U.S.A.) and the splice variants were detected with polymerase chain reaction (PCR), T7 and Sp6 primers being used for the pcDNA3 vector: in this way, the amplification of internal CDKN2A transcripts could be avoided. PCR reactions were performed in GoTaq Hot Start mix (Promega, Madison, WI, U.S.A.). The PCR products were run on $2 \%$ agarose gel and photographed, and the bands were purified from the gel and sequenced (Fig. 2b). Sequences were analysed with the BioEdit program (http:// www.mbio.ncsu.edu/BioEdit/bioedit.html).

\section{Results}

The mutation is situated in intron 1 (IVS1+37 G/C) and has so far been mentioned twice in case reports: in a FAMMM pedigree and in a single patient with primary melanoma, both from Italy, ${ }^{5,6}$ and summarized in a review paper by Orlow et al. $^{8}$ In silico assays reported in one of these papers did not reveal any predicted defects in mRNA processing caused by the mutation and it was therefore qualified as a mutation of unknown significance.

Our sequence analysis involving the comparison of the mRNA arising from the wild-type and that from the mutant minigene revealed a differential splicing pattern (Fig. 2b): the shorter band corresponds to a 339-nt CDKN2A sequence as a result of normal splicing, while the 459-nt upper band relates to an extended alternative splice product formed by the addition of a 120-nt sequence of intron 1 as an exon (Fig. 2c). This result was identically obtained in three independent transfection experiments on HeLa cells, suggesting that the 
in vitro minigene approach applied was suitable for studying the effects of the identified intronic IVS1+37 G/C mutation on splicing.

\section{Discussion}

Whether the aberrant mRNA is stable and translated or not, our results indicate that it may play a pathogenetic role in familial melanoma. If the aberrant mRNA were translated, the inclusion of the cryptic exon would result in a frameshift and an early stop codon would change the structure of the p16 protein; if the aberrant mRNA were not stable, it would reduce the quantity of functional p16 indirectly.

In conclusion, the segregation of the IVS1+37 G/C intronic CDKN2A mutation with FAMMM in the extensive melanomaprone family and the results of our in vitro minigene experiments suggest that this mutation may have a pathogenetic role, most likely involving alteration of the splicing of the CDKN2A primary mRNA. Besides CDKN2A coding mutations, intronic mutations of the loci may contribute to melanoma susceptibility and identification of these mutations would facilitate our understanding of why the frequency of germline coding mutations of the CDKN2A gene is lower than expected in melanoma-prone families linked to chromosome 9 p21.

\section{What's already known about this topic?}

- The major locus for melanoma predisposition is the cell cycle regulatory CDKN2A gene on chromosome 9 p21.

- However, the frequency of germline coding mutations of the CDKN2A gene is lower than expected in melanoma-prone families linked to chromosome 9p21.

\section{What does this study add?}

- We report the detection and functional data on the possible pathogenetic role of a rare IVS1+37 G/C intronic mutation of the CDKN2A gene found in a Hungarian melanoma-prone family.

- This mutation most likely involves alteration of the splicing of the CDKN2A primary mRNA.

\section{References}

1 Goldstein AM, Chan M, Harland M et al. High-risk melanoma susceptibility genes and pancreatic cancer, neural system tumors, and uveal melanoma across GenoMEL. Cancer Res 2006; 66:9818-28.

2 Newton Bishop JA, Harland M, Bennett DC et al. Mutation testing in melanoma families: INK4A, CDK4 and INK4D. Br J Cancer 1999; 80:295-300.

3 Majore S, Catricala C, Binni F et al. CDKN2A: the IVS2-105A/G intronic mutation found in an Italian patient affected by eight primary melanomas. J Invest Dermatol 2004; 122:450-1.

4 Loo JC, Liu L, Hao A et al. Germline splicing mutations of CDKN2A predispose to melanoma. Oncogene 2003; 22:6387-94.

5 Della TG, Pasini B, Frigerio S et al. CDKN2A and CDK4 mutation analysis in Italian melanoma-prone families: functional characterization of a novel CDKN2A germ line mutation. Br J Cancer 2001; 85:836-44.

6 Pastorino L, Bonelli L, Ghiorzo P et al. CDKN2A mutations and $\mathrm{MC} 1 \mathrm{R}$ variants in Italian patients with single or multiple primary melanoma. Pigment Cell Melanoma Res 2008; 21:700-9.

7 Harland M, Mistry S, Bishop DT et al. A deep intronic mutation in CDKN2A is associated with disease in a subset of melanoma pedigrees. Hum Mol Genet 2001; 10:2679-86.

8 Orlow I, Begg CB, Cotignola J et al. CDKN2A germline mutations in individuals with cutaneous malignant melanoma. J Invest Dermatol 2007; 127:1234-43. 
IV. 


\title{
Melanoma-Predisposing CDKN2A Mutations in Association with Breast Cancer: A Case-Study and Review of the Literature
}

\author{
Klára Balogh et al.* \\ Department of Dermatology and Allergology, \\ University of Szeged \\ Hungary
}

\section{Introduction}

The authors present the case of a 33-year-old female patient who developed melanoma, ductal adenocarcinoma of the breast and primary pancreas adenocarcinoma nearly simultaneously, but independently of each other. Past medical history of the patient was unremarkable, however, in her family history gastric, laryngeal and breast cancer was noted on the paternal side. The occurrence of multiple primary tumours in a relatively young individual, together with the family history of different malignancies, suggested that there might be genetic predisposition to the development of multiple tumours. In this chapter we present the case of the young female patient suffering from three independent primary tumours and review current data on the germ-line mutations detected to date in the CDKN2A gene, in view of the association not only with melanoma, but also with additional malignant diseases, such as pancreas carcinoma and breast cancer.

\section{Case presentation and review of the literature}

\subsection{Clinical observations and management}

The 33-year-old female patient presented with a lesion which had the clinical appearance of a verrucous pigmented nevus on the left lower back for the preceeding 2 years. Histology of the excised lesion showed a pT2b stage malignant melanoma consisting of exulcerated nodular (Fig. 1a) and superficial (Fig. 1b) areas with $1.524 \mathrm{~mm}$ Breslow's thickness and Clark's level II-III. Based on the above results, reexcision and sentinel lymph node biopsy were performed. Histological examination of the sentinel lymph nodes from the left axillary

\footnotetext{
${ }^{*}$ Edina Nemes¹, Gabriella Uhercsák², Zsuzsanna Kahán², György Lázár³, Gyula Farkas³, Hilda Polyánka ${ }^{4}$, Erika Kiss ${ }^{1}$, Rolland Gyulai ${ }^{1}$, Erika Varga ${ }^{1}$, Erika Keresztné Határvölgyi ${ }^{5}$, László Kaizer ${ }^{6}$, Lajos Haracska ${ }^{5}$, László Tiszlavicz ${ }^{6}$, Lajos Kemény ${ }^{1,4}$, Judit Oláh ,Márta Széll1 ${ }^{4}$,

1 Department of Dermatology and Allergology,

2 Department of Oncology,

3 Department of Surgery,

4 Dermatological Research Group of the Hungarian Academy of Sciences,

5 Institute of Genetics, Biological Research Centre of the Hungarian Academy of Sciences

6 Department of Pathology, all at the University of Szeged,
} 
and left inguinal regions did not reveal any metastases. Staging investigations - chest $\mathrm{x}$-ray, ultrasound scan of the abdomen, pelvis, left axillary and left inguinal regions - did not find any regional lymph node or internal organ involvement. Results of laboratory tests, including serum lactate dehydrogenase levels, were all normal. The patient received low dose (3 MIU - 3 times a week sc.) interferon-a 2a treatment for one year.
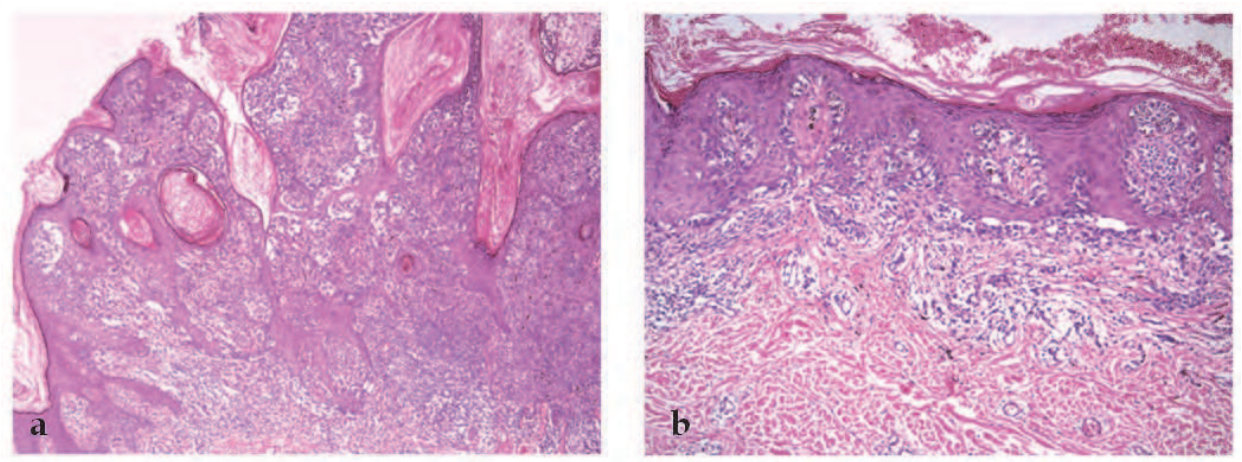

Fig. 1. Histology of primary malignant melanoma. Hematoxylin-eosin staining of the excised lesion revealed its combined nature having nodular (a) and superficial (b) parts.
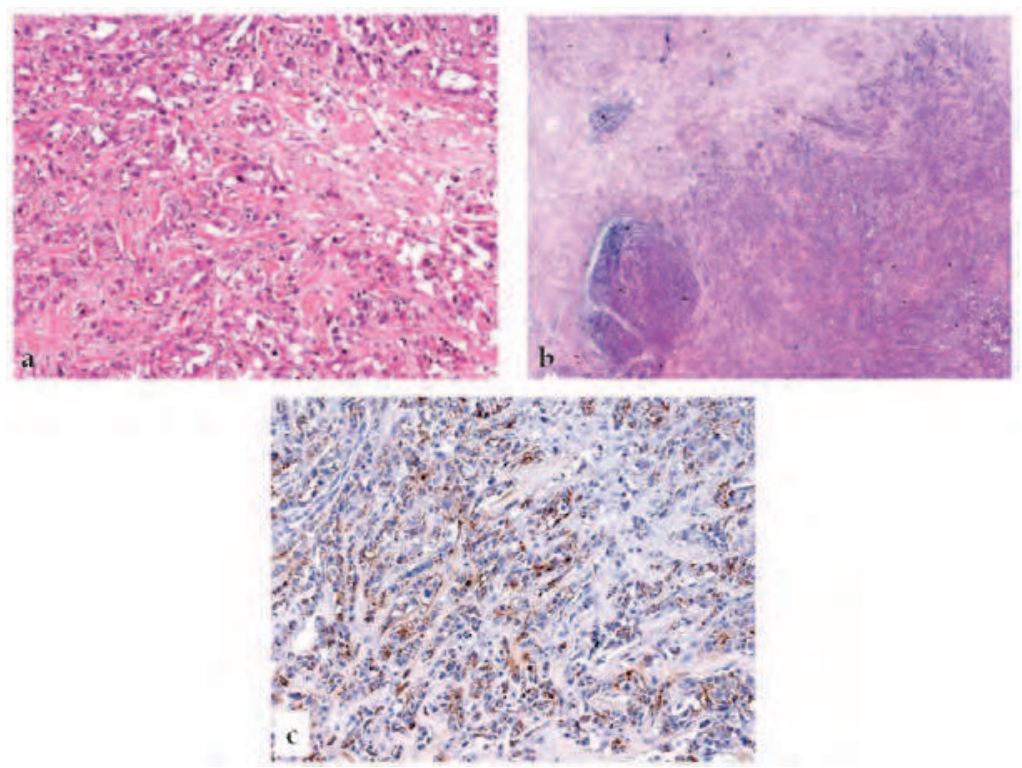

Fig. 2. Histology and immunohistochemistry of the breast adenocarcinoma. The marked nuclear polymorphism, lack of tubular forming and high number of mitoses indicated the diagnosis of ductal adenocarcinoma (a). Two of the excised 14 lymph nodes proved to have metastases with capsular invasion (b). HMF-G staining indicated a poorly differentiated breast adenocarcinoma (c). 
Fifteen months after the completion of interferon treatment, the patient noted a firm nodule in the lateral area of the left breast which was biopsied. Histological examination revealed four foci of Grade III invasive ductal adenocarcinoma (Fig. 2a). Grading was based on the marked nuclear polymorphism, lack of tubular forming and high number of mitoses. In view of the multifocal malignant enhancement seen on the MRI and the histology report of the core biopsy, the patient underwent left mastectomy with radical left axillary lymph node dissection. Metastases infiltrating the capsule were found in 2 out of the 14 lymph nodes examined (Fig. 2b).

With regards to the diagnosis of breast cancer, PET CT was performed in order to exclude dissemination. The PET CT suggested the presence of a malignant lesion in the region of the pancreas. Abdominal MRI revealed a neoplasm of $2 \mathrm{~cm}$ in diameter in the caudal part of the pancreas (Fig. 3a). Laboratory investigations showed elevated CA 19-9 and serum amylase levels. On explorative laparotomy, an irresectable tumour mass involving the pancreas, liver and the regional lymph nodes was found. The tumour was biopsied and was initially described as metastatic adenocarcinoma (Fig. 3b). However, further immunohistochemical (CK20 and CK7) and mucin staining (MUC5AC) of the specimens from the breast (Fig. 2c) and abdominal mass (Fig. 3c), clearly differentiated two tumours: 1. poorly differentiated [CK7+/CK20-/MUC5AC-] breast adenocarcinoma, 2. moderately differentiated $[\mathrm{CK} 7+/ \mathrm{CK} 20+/ \mathrm{MUC} 5 \mathrm{AC}+])$ pancreas adenocarcinoma. This verified the gastrointestinal origin of the primary tumour i.e. the abdominal mass originated from the primary pancreas adenocarcinoma.
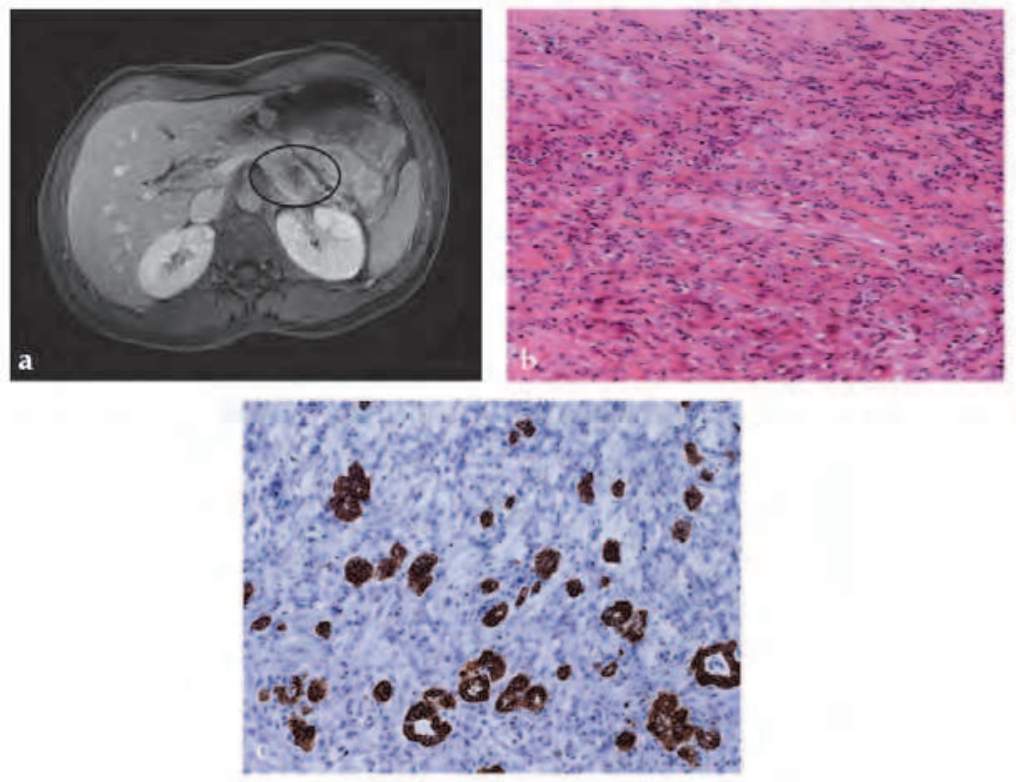

Fig. 3. Diagnosis of pancreas adenocarcinoma. Abdominal MRI showed a neoplasm in the caudal part of the pancreas (a). Hematoxylin-eosin staining indicated the malignant nature of the excised tumour (b). CK-20 immunohistochemistry indicated a moderately differentiated metastatic adenocarcinoma with globular components in the pancreas (c). 
With regards to the case of multiple primary tumours, the patient received gemcitabine plus cisplatin combined chemotherapy. Repeated laparotomy performed on follow up after the treatment course noted complete regression of the previously detected primary tumours and tumour-free abdominal organs. Subsequently, the results of all re-staging investigations were negative and tumour markers returned to the normal range.

\subsection{Genetic investigations}

During the course of the patient's treatment, her family history for tumours was investigated. She reported that her father was suffering from gastric and laryngeal carcinoma and that her father's sister had died from breast cancer at a young age several decades ago. (Fig. 4a). We therefore set out to perform genetic investigations and check whether there are any cancer predisposing factors, causing the high prevalence of simultaneously appearing independent primary malignancies in the patient and in her family. The blood samples used in this study were taken after written informed consent of the patient and family members. The protocol was approved by the Local Ethics Committee in adherence to the Helsinki guidelines. Two $\mathrm{ml}$ of venous blood was taken, genomic DNA was isolated using the QIAmp DNA Blood Mini Kit (Qiagen, Hilden, Germany) and exons $1 \alpha, 1 \beta, 2$ and 3 of the CDKN2A gene were amplified with the Resequencing Amplicon probe system (http://www.ncbi.nlm.nih.gov/genome/probe/reports/probereport; probe IDs: RSA001284450, RSA000045423, RSA000942236, RSA000942233). The PCR products were purified using the Quantum Prep PCR Kleen Spin Columns (Bio-Rad, Hercules, CA, USA). The genetic analysis revealed that the patient and her father both carried the R24P CDKN2A mutation in a heterozygote form (Fig. 4b). The mutation is located in exon 1a, therefore only the p16 INK4a transcript variant is affected (Fig. 4c).

a
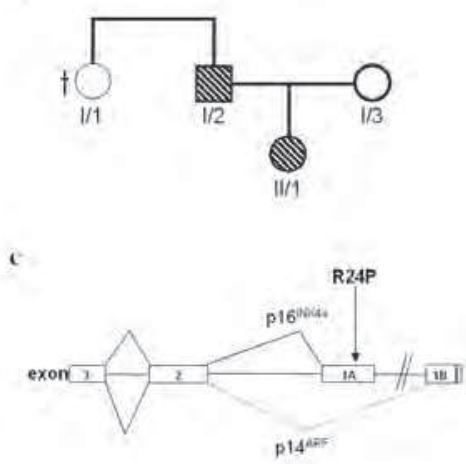

b

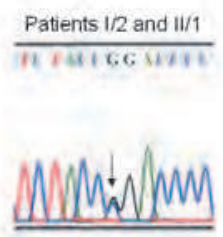

G/C heterozygote

CGG>CCG

Arg $>$ Pro

R24P

Fig. 4. Genetic analysis of the patient and her family. The 33-year-old female patient (II/1, melanoma, breast and pancreas carcinoma), her father (I/2; gastric and laryngeal carcinoma) and her mother (I/3; without any malignant diseases) were investigated. The father's sister (I/1) had died from breast cancer at a young age several decades ago, therefore her genetic investigation could not be performed (a). Sequence analysis revealed that probands I/ 2 and II/1 carried a missense mutation (G/C) in exon 1a of the CDKN2A gene (b), causing an arginine to proline amino acid change in codon 24 (R24P) affecting only the p16 INK4a transcript variant (c). 
Because of the occurrence of breast adenocarcinoma in our patient's medical history, it was also tested whether she carried mutations in the BRCA1 and BRCA2 genes. The 15 most commonly occurring (so-called "hot spot") BRCA mutations were studied (Table 1), but according to the sequencing data, none of them could be detected in the case of the female patient. After having received these data, we did not perform the BRCA1 and BRCA2 examinations on the genetic material of her father.

Based on these results, we hypothesize that the detected R24P mutation of the CDKN2A gene may be responsible for the melanoma and pancreas carcinoma of the 33-year-old female patient. At the same time, it may have contributed to the genetic predisposition for the breast cancer of our patient and her late aunt, as well as to the gastric and laryngeal carcinoma of her father. In the coming chapter we review current literature data about the possible breast cancer predisposing nature of CDKN2A mutations in general and the R24P mutation in particular.

\subsection{The R24P mutation of CDKN2A has been worldwide implicated as a melanoma- predisposing genetic factor}

The R24P germline mutation of the CDKN2A gene was first described by Australian authors. Holland et al. (Holland et al., 1995) reported on a survey performed on 17 melanoma-prone families in 1995 and they identified this mutation in one of the studied families. Since that time many independent studies proved the melanoma-predisposing nature of this mutation being one of the most widespread among the so-far identified disease-associated mutations of the CDKN2A gene. Soon after the first detection, the R24P mutation was also identified in US melanoma-prone families as early as in 1998 (Monzon et al., 1998) and its function was also assessed by yeast two-hybrid assay. According to the results, the R24P missense mutation almost completely abrogates the binding activity of the protein, thus explaining the disease-predisposing nature of the mutation. Following the "New World" publications of the R24P mutation, authors also reported it in European melanoma-prone families: it was reported in 1998 in the UK (MacKie et al., 1998) in the case of a relatively young (y31) male patient with multiple primary melanomas and in the case of two unrelated melanoma-prone kindreds in France (Soufir et al., 1998). This is why review papers from the mid-2000s refer to the R24P mutation as one of the most widespread CDKN2A mutations in the World, contributing to the genetic predisposition to familial, as well as multiple primary melanoma. To our best knowledge, ours is the first report on the identification of the R24P mutation in a Central-European family.

Taken together, the above summary well reflects that the R24P CDKN2A mutation is a relatively frequent one all over the World. Whether it is an ancient founder mutation that was spread to many geographical locale in the past, or independent mutation events happened, would be interesting to investigate (Table 2). There have been already very good examples provided where similar intriguing questions were addressed. Hashemi et al. (Hashemi et al., 2001) demonstrated that the 113insR CDKN2A mutation found only in Southern Scandinavia is a founder mutation that arose approximately 98 generations ago. Similarly, the G101W mutation that is frequent in Northern Italy, Southern Germany and France, is also a founder mutation that arose approximately 97 generations ago (Ciotti et al., 2000). Although the mutations appeared around the same time, the latter one is spread worldwide, while the Scandinavian 113insR could not be so far identified in any other geographical locale apart from Sweden. In view of these findings, it would also be very interesting to perform the haplotype mapping of R24P carrier patients to figure out whether it is also a founder mutation and if so, when it occurred in the past. 


\begin{tabular}{|c|c|}
\hline Gene and Mutation & Primers \\
\hline \multirow{2}{*}{ BRCA1 3135delCATT } & TCTGGGTCCTTAAAGAAACAAAGTC \\
\hline & ACTTGGAATGTTCTCATTTCCC \\
\hline \multirow{2}{*}{ BRCA1 3153delAG } & CATCTCAGTTCAGAGGCAACG \\
\hline & TGCATGACTACTTCCCATAGGC \\
\hline \multirow{2}{*}{ BRCA1 3875delGTCT } & TCACCCATACACATTTGGCTC \\
\hline & AATCCATGCTTTGCTCTTCTTG \\
\hline \multirow{2}{*}{ BRCA1 4184delTCAA } & CGTTGCTACCGAGTGTCTGTC \\
\hline & GACGTCCTAGCTGTGTGAAGG \\
\hline \multirow{2}{*}{ BRCA1 185delAG } & GGTTGGCAGCAATATGTGAAA \\
\hline & TGCAGAACCAATCAAGACAGA \\
\hline \multirow{2}{*}{ BRCA1 300T>G } & GGCTCTTAAGGGCAGTTGTG \\
\hline & AGAAAGGCAGTAAGTTTCTAATACCTG \\
\hline \multirow{2}{*}{ BRCA1 1294del40 } & TGTAATGATAGGCGGACTCCC \\
\hline & CTCAGGATGAAGGCCTGATG \\
\hline \multirow{2}{*}{ BRCA1 2382GT } & GACATGACAGCGATACTTTCCC \\
\hline & TGTTGCACATTCCTCTTCTGC \\
\hline \multirow{2}{*}{ BRCA1 5382insC } & GTGTCTGCTCCACTTCCATTG \\
\hline & CGAGACGGGAATCCAAATTAC \\
\hline \multirow{2}{*}{$\begin{array}{c}\text { BRCA2 6079delAGTT, 6174delT, } \\
\text { 6274delT }\end{array}$} & $\begin{array}{l}\text { GTTGTTACGAGGCATTGGATG } \\
\end{array}$ \\
\hline & GGAAACTTGCTTTCCACTTGC \\
\hline \multirow{2}{*}{ BRCA2 8034insAG } & TATGGCAGATTTAGCAGGAGG \\
\hline & TCGAGAGACAGTTAAGAGAAGAAAGA \\
\hline \multirow{2}{*}{ BRCA2 8138delCCTTT } & CTGGCCTCAAGCAATCCTC \\
\hline & TTGACATGGAAGTCACAGACTACAC \\
\hline \multirow{2}{*}{ BRCA2 9326insA } & TCCACTACTAATGCCCACAAAG \\
\hline & CACCTCAGAACAAGATGGCTG \\
\hline
\end{tabular}

Table 1. Hotspot mutations of the BRCA1 and BRCA2 genes and the primers used for the amplification of the surrounding gene regions.

\begin{tabular}{|c|c|c|c|}
\hline \multicolumn{3}{|c|}{ Cancer-prone families identified to carry the R24P CDKN2A mutation } \\
\hline $\begin{array}{c}\text { Cancer types detected in the } \\
\text { pedigrees }\end{array}$ & Geographic locale & Authors & $\begin{array}{c}\text { Date of } \\
\text { publication }\end{array}$ \\
\hline Melanoma & Australia & Holland et al. & 1995. \\
\hline Melanoma & Canada & Monzon et al & 1998. \\
\hline Melanoma & France & Soufir et al. & 1998. \\
\hline Melanoma & U.K. & Mackie et al. & 1998. \\
\hline $\begin{array}{c}\text { Sarcoma } \\
\text { Melanoma* } \\
\text { Cancer of the esophagus* } \\
\text { Pancreas carcinoma* }\end{array}$ & North America \\
$\begin{array}{c}\text { Carcinoma of the mouth and throat* } \\
\text { Colon carcinoma* } \\
\text { Lung carcinoma* } \\
\text { Cancer of the gallbladder* } \\
\text { Breast carcinoma* }\end{array}$ & Lynch et al. & 2002. \\
\hline $\begin{array}{c}\text { Melanoma } \\
\text { Bladder cancer }\end{array}$ & Italy & Landi et al. & 2004. \\
\hline
\end{tabular}

* The mutation was not identified in the late carcinoma patients but in a descendant with sarcoma.

Table 2. Publications on the R24P CDKN2A mutation and cancer types detected in the R24P families. 


\subsection{CDKN2A germline mutations in multiple primary malignancies}

The idea that CDKN2A mutations may contribute to the predisposition of other primary malignancies beside melanoma came early in the middle of 90 s, right after the identification of the gene's role in melanoma predisposition. Monzon et al. (Monzon et al., 1998) performed epidemiology and genetic studies on multiple primary melanoma cases and melanoma cases associated with multi-organ primary malignancies. They found that about 5 percent of patients have one or more additional primary lesions. This higher-than-expected prevalence of multiple primary melanomas may be due to excessive sun exposure, but according to the authors, genetic basis may also lay behind the phenomena. As supporting data, Monzon et al. claimed that patients with multiple primary melanomas very often have a family history of the disease. From epidemiology studies it was already known at that time that approximately 10 percent of melanoma cases have family background, which suggested genetic predisposition. Moreover, in 20 percent of the familial melanoma cases CDKN2A mutations could also be detected. The authors also claimed that in such families pancreas cancer also has a higher prevalence (Monzon et al., 1998).

The first in-depth analysis of this topic was reported in 1995 (Goldstein et al., 1995) by Goldstein and colleagues who compared the prevalence of other tumours in melanomaprone families harboring or not harboring CDKN2A mutations. According to their analysis, CDKN2A mutation-harbouring melanoma-prone families have a 13-fold increased risk to develop pancreas cancer compared to those who do not carry such mutations. There was only one breast cancer patient mentioned in the paper who carried a mutant CDKN2A allele, while no breast cancer case could be detected in the group of melanoma-prone families with wild type CDKN2A alleles. The authors cited previous contrasting data demonstrating that the incidence of other types of cancers in melanoma-prone families in the US is not increased (Bohn et al., 2010). Moreover, another workgroup in the 80s suggested that patients with familial melanoma even had fewer other types of cancers than those suffering from sporadic melanoma (Kopf et al., 1986). These early data had been overwritten since and it is mainly due to the combined in-depth epidemiological and genetic studies performed within this special group of melanoma patients in the last 20 years.

As CDKN2A mutation studies became more and more intensive with the enrolment of centres from all over the world from Australia to the US through Europe, not only the genetic predisposition of familial melanoma but also its co-morbidities became recognized. This is a bright example of how genetic examinations can inspire epidemiological studies and shed light to connections of different diseases and their common predisposing factors. With reviewing several relevant papers we aim to demonstrate the above notion.

As early as 1999, Ghiorzo et al. (Ghiorzo et al., 1999) reported that the most prevalent malanoma-predisposing mutation of the Mediterranian, the G101W, was associated not only with a higher incidence of pancreatic malignancies, but also with breast cancer. In contrast, melanoma-prone families from the same geographical locale without CDKN2A mutations did not exhibit any non-melanoma neoplasias. The authors emphasized that the clinical-epidemiological study was conducted in a small geographical region where the sun and other types of environmental exposures of the individuals were approximately the same, therefore, differences of environmental factors could not account for the differential appearance of disease phenotypes. The authors therefore suggested that determining the underlying CDKN2A mutation in melanoma-prone families may have important implications not only for melanoma but also for further non-melanoma risk assessments. 
In 2002, Lynch et al (Lynch et al., 2002) published the results of a survey where they aimed to elucidate the genetic background of the so-called FAMMM-pancreas carcinoma syndrome. They reported that their familial pancreas carcinoma database comprises of 159 families, of which 19 (12\%) showed the FAMMM cutaneous phenotype. Lynch and coworkers studied the family tree, the history and the genetic background of eight families in detail. Most of the families had five-generation history of cancer where pancreas carcinoma predominated, but many other types of cancers were also prominent. A female patient of one of the families exhibited very similar multiple primary tumours as our 33-year-old patient: she had melanoma malignum, pancreas carcinoma and breast cancer with an onset at the age of 51, 56 and 61, respectively. Although the two patients exhibited a very similar pattern of tumours, there are two striking differences. The patient in the US study was already over the age 50 when her "march" of diseases started, while the Hungarian patient we are reporting now was only at the beginning of her 30s when the multiple primary tumours started. The other difference is that in the case of the Hungarian patient a melanoma-predisposing CDKN2A mutation could be detected, while in the case of the US female patient no such mutation was apparent. At the same time, Lynch et al. could also detect the previously described R24P mutation in another family of the study. In that extended family, a broad spectrum of cancers was apparent with the dominancy of pancreas carcinoma and malignant melanoma. In the case of a female family member, breast carcinoma was detected at her age of 60 , but there was no report on any other malignancies. Whether she had any other predisposing genetic factors (eg BRCA1 or BRCA2 mutations) or her case was considered as a sporadic one is not discussed in the paper. Lynch et al. drew the conclusion that the cancer spectrum of the studied families in concert with CDKN2A mutations suggest a new putative hereditary carcinoma syndrome referred to as FAMMMPC. The big variety of other types of cancers they demonstrated in the eight studied families raise the possibility that the predisposing CDKN2A mutations may contribute not only to FAMMM and PC but also to other types of malignancies, too. In this respect the case we present in this paper is also a supporting one to confirm the notion of Lynch et al.

Since Lynch and co-workers provided the first genetic study in FAMMM-PC syndrome (Lynch et al., 2002), the existence of such an entity became widely accepted and recent papers from various geographical locale were published in this topic. Bartsch and coworkers performed a survey in German pancreas cancer-prone families. Out of 110 such families, they identified 18 in which both melanoma and pancreas cancer occurred. The 18 families could be divided into two subgroups: five families with FAMMM-PC syndrome and $13 \mathrm{PC} /$ melanoma families without the multiple mole phenotype (PCMS families). The authors found that the co-occurrance of pancreas carcinoma and melanoma was similar in the two subgroups; however, the prevalence of other tumour types, especially breast carcinoma was significantly higher in the latter group. Bartsch et al. checked CDKN2A germline mutations and mutations of genes contributing to breast cancer susceptibility. They identified CDKN2A mutations in 2 of the PCMS families but they could not identify any breast cancer susceptibility ones, only a co-segregating BRCA2 variant in a PCMS family without breast cancer. The conclusion they drew from the above was that families with an accumulation of pancreas cancer and melanoma show a large variety of phenotypic expression. Finally, the authors warn that more PC/melanoma families need to be analysed to clarify whether they represent a variation of the FAMMM-PC syndrome or there are two distinct hereditary cancer syndromes. The case we present in this paper may be considered as a reflection to their call since the family we studied does not show the multiple mole 
phenotype. It may be classified as a PCMS family with an apparent CDKN2A mutation that is responsible for the malignant melanoma and pancreas carcinoma and possibly also contributing to breast carcinoma.

In an extended study performed in Southern Scandinavia, Borg et al. (Borg et al., 2000) found that patients carrying the 113insArg melanoma-predisposing founder mutation, pancreas carcinoma and as the second most frequent malignancy, breast carcinoma can also be frequently detected. The authors studied nine 113insArg mutation-carrying families and 42 CDKN2A mutation-free melanoma-prone families. The incidence of multiple primary malignancies was significantly higher in 113insArg families compared to those free of any genetic alteration in the CDKN2A gene. Borg et al. therefore claimed that the CDKN2A 113insArg mutation carriers have an increased risk not only to malignant melanoma but also to pancreas and breast cancer.

Prowse et al. presented a very elegant work in 2003 (Prowse et al., 2003) with an approach from the opposite direction. They studied BRCA1 and BRCA2 mutation-free breast cancerprone families presenting multiple cases of early onset breast cancer and tried to find out what type of other gene mutations could predispose them to develop the disease. According to their estimation, only one third of breast cancer-prone families carry either BRCA1 or BRCA2 mutations, therefore other candidate genes contributing to disease predisposition must also be considered. The fact that eight families out of the 31 reported multiple cases of pancreas cancer and malignant melanoma prompted the authors to study the CDKN2A gene in detail. In one of the studied families, a novel CDKN2A mutation was identified: the IVS1-1G>C intronic mutation. The nucleotide substitution occurs at a highly conserved base in the $3^{\prime}$ splice junction of intron 1, thus both p16 INK4a and p14ARF transcript variants are affected. The authors performed a functional analysis to prove that the mutation indeed causes the emergence of an aberrant splice variant. Owing to the fact that two proteins playing pivotal role in cell cycle regulation are affected by the same mutation, it is plausible to hypothesize that it may be of key importance in predisposition to various forms of malignancies.

$\mathrm{Up}$ to this point rare mutations of the CDKN2A gene were discussed in relation to predisposition to melanoma and other malignant diseases. However, a Polish workgroup also provided data on a relatively common variation of the same gene, the A148T polymorphism also contributed to disease pathogenesis. Debniak and co-workers (Debniak et al., 2005b) first showed that the A148T variant having a 3\% allele frequency in the general Polish population was a melanoma-predisposing factor with an odds ratio of 2.5. Next they studied whether the same variant exhibits breast-cancer-predisposing nature too and found that the odds ratio associated with the CDKN2A allele for women diagnosed with breast cancer before the age of 50 was 1.5 and after the age of 50 it was 1.3. The effect was the strongest for women diagnosed at or before the age of 30 (Debniak et al., 2005a), suggesting a role of the A148T polymorphism in breast cancer predisposition. As a next step, the workgroup performed a population-based study where they compared the genotypes and the allele frequency of the A148T polymorphism in the group of 3,583 unselected cancer cases and 3,000 random controls. They found a positive association between the A148T variant and lung cancer and colorectal cancer with odds ratios of 2.0 and 1.5, respectively. The authors concluded that the A148T variant of the CDKN2A gene may contribute to multi-organ cancer risk (Debniak et al., 2006). How this variant reveals its diseasepredisposing effect is still unclear. It has been demonstrated that the A148T allele did not have a major effect on the protein function (Ranade et al., 1995; Lilischkis et al., 1996); 
however, according to Debniak and co-workers (Debniak et al., 2005a) we can not exclude the possibility that it subtly affects p16 INK4a function or reduces its level of expression. Moreover, they could demonstrate that the A148T variant is in strong linkage disequilibrium with a promoter polymorphism of the CDKN2A gene, the P493 variant (Debniak et al., 2005b). Taken together, the Polish workgroup provided a very demonstrative set of data suggesting that beside the rare variants with high penetrance, a relatively common low-penetrance CDKN2A variant may also contribute to the pathogenesis of various cancer types. These findings may gain importance in the discovery of the pathogenesis of both familial and sporadic cancers.

The melanoma-predisposing nature of the A148T CDKN2A polymorphism have so far been most extensively studied in the Polish population, but sporadic data on the same variant exist in other populations. For example, Nagore and co-workers (Nagore et al., 2009) reported on the identification of two women in the Spanish population carrying the same A148T CDKN2A polymorphism and one of them having a hereditary breast/ovarian cancer family pedigree. At the same time, the authors claim that they could not find a significant difference in the allele frequency of the A148T variant in the general Spanish population and the studied breast cancer/melanoma patients' population. Nagore et al. could identify two more CDKN2A mutations in their study population: the V59G and the A85T, both of them frequently occurring in women suffering from both malignant melanoma and breast carcinoma. As a conclusion, the authors claim that because CDKN2A mutations are infrequent in female patients with melanoma and breast cancer, other deleterious variants such as mutations in BRCA1, BRCA2, TP53 must be studied in these types of patients' groups.

The above notion of Nagore et al. was confirmed by Monnerat and co-workers (Monnerat et al., 2007) who studied BRCA1, BRCA2, TP53 and CDKN2A genes in a group of female patients presenting both melanoma and breast cancer. The authors found that patients with a positive family history of both of these malignancies often carry variants of the aformentioned genes with a higher frequency than those without a family history. This study and all the above cited ones prompt us to draw two important conclusions: the cooccurrence of primary multi-organ malignancies are very often genetically determined but to reveal the exact pattern of genetic variants (the combination of high- and low-risk susceptibility factors), a well-defined set of genes must be studied in detail in large cohorts of patients. At the same time, we believe that single cases, for instance the one we present in this report, may add valuable data to the topic.

Until the mid-2000s, there was no opportunity to study the co-morbidities of familial melanoma in large cohorts of patients. The international GenoMEL Consortium, however, made it possible to perform large scale surveys in this topic and several hundreds of melanoma-prone families could be investigated both for their genetic predisposition and for their co-existing malignancies. Goldstein and the co-workers (Goldstein et al., 2007) of the GenoMEL Consortium published the results of their large scale survey in 2006. They studied 385 melanoma-prone families and out of them 39\% carried one of the melanomapredisposing CDKN2A mutations. The lowest ratio of such mutation carriers was identified in Australia, where the incidence of sporadic melanoma is higher than that of in Europe and in North America. This difference is also reflected in the relationship between pancreas cancer and CDKN2A mutations: while within the European and North American melanoma-prone families a clear connection could be identified between the mutation carrier status and pancreas carcinoma, no such relationship could be discovered in the 
Australian patients. The authors hypothesize that the lack of pancreas cancer-CDKN2A mutation relationship in Australia reflects the divergent spectrum of CDKN2A mutations detected in Australian melanoma-prone families versus those from North America and Europe. In a follow-up paper (Goldstein et al., 2006), the authors extended their survey to neural system tumours and to uveal melanoma but found no association between CDKN2A mutations and these two malignancies either.

\section{Conclusion}

In this paper we presented the case of a 33-year-old female patient with the occurrence of three primary multi-organ malignancies, malignant melanoma, pancreas and breast carcinoma within a short period of time. The family history of the patient prompted us to perform a genetic study and we identified the melanoma-predisposing R24P CDKN2A germline mutation in her case as well as in her father, suffering from gastric and laryngeal carcinomas. Since the late aunt of the young female patient died of breast cancer at the age of her 20s several decades ago, we also surveyed the patient for the presence of BRCA1 and BRCA2 hotspot mutations but found no alterations in her case. Although we can not exclude the possibility that other predisposing gene variants may have contributed to the breast cancer of the patient, we suggest that the disclosed R24P CDKN2A mutation may have played a key role in the pathogenesis of her multi-organ primary malignancies.

Surveying the relevant literature clearly revealed that CDKN2A germline mutations are highly accepted as predisposing genetic factors for patients who suffer from co-existing pancreas carcinoma and malignant melanoma. However, no such consensus exists for the association of CDKN2A germline variants and the primary multiple occurrence of melanoma malignum and breast cancer. Studies performed in relatively small cohorts of patients resulted in contradictory data: some of them supporting while others rejecting the notion of the breast cancer-predisposing nature of CDKN2A germline mutations. To resolve this problem, extended studies on a wide range of low- and high-penetrance genetic predisposing factors must be examined on a multicentric base. We believe that single cases such as the one we presented in this paper may contribute to the understanding of the role of genetic susceptibility and environmental factors in the pathogenesis of multiple primary malignancies.

\section{Acknowledgment}

The work was supported by grants TÁMOP-4.2.1/B-09/1/KONV-2010-0005, TÁMOP-4.2.208/1-2008-0001, ETT-429-07 and OTKA 5K302.

\section{References}

Bohn, O.L., Fuertes-Camilo, M., Navarro, L., Saldivar, J., \& Sanchez-Sosa, S. (2010). p16INK4a expression in basal-like breast carcinoma. International Journal of Clinical and Experimental Pathology, Vol.3, No.(6), pp. 600-607.

Borg, A., Sandberg, T., Nilsson, K., Johannsson, O., Klinker, M., Masback, A., Westerdahl, J., Olsson, H., \& Ingvar, C. (2000). High frequency of multiple melanomas and breast 
and pancreas carcinomas in CDKN2A mutation-positive melanoma families. Journal of the National Cancer Insitute., Vol.92, No.(15), pp. 1260-1266.

Ciotti, P., Struewing, J.P., Mantelli, M., Chompret, A., Avril, M.F., Santi, P.L., Tucker, M.A., Bianchi-Scarra, G., Bressac-de Paillerets, B., \& Goldstein, A.M. (2000). A single genetic origin for the G101W CDKN2A mutation in 20 melanoma-prone families. American Journal of Human Genetics, Vol.67, No.(2), pp. 311-319.

Debniak, T., Gorski, B., Huzarski, T., Byrski, T., Cybulski, C., Mackiewicz, A., GozdeckaGrodecka, S., Gronwald, J., Kowalska, E., Haus, O., Grzybowska, E., Stawicka, M., Swiec, M., Urbanski, K., Niepsuj, S., Wasko, B., Gozdz, S., Wandzel, P., Szczylik, C., Surdyka, D., Rozmiarek, A., Zambrano, O., Posmyk, M., Narod, S.A., \& Lubinski, J. (2005a). A common variant of CDKN2A (p16) predisposes to breast cancer. Journal of Medical Genetics, Vol.42, No.(10), pp. 763-765.

Debniak, T., Scott, R.J., Huzarski, T., Byrski, T., Rozmiarek, A., Debniak, B., Gorski, B., Cybulski, C., Medrek, K., Mierzejewski, M., Masojc, B., Matyjasik, J., Zlowocka, E., Teodorczyk, U., Lener, M., Klujszo-Grabowska, E., Nej-Wolosiak, K., Jaworowska, E., Oszutowska, D., Szymanska, A., Szymanska, J., Castaneda, J., van de, W.T., Suchy, J., Kurzawski, G., Oszurek, O., Narod, S., \& Lubinski, J. (2006). CDKN2A common variant and multi-organ cancer risk--a population-based study. International Journal of Cancer, Vol.118, No.(12), pp. 3180-3182.

Debniak, T., Scott, R.J., Huzarski, T., Byrski, T., Rozmiarek, A., Debniak, B., Zaluga, E., Maleszka, R., Kladny, J., Gorski, B., Cybulski, C., Gronwald, J., Kurzawski, G., \& Lubinski, J. (2005b). CDKN2A common variants and their association with melanoma risk: a population-based study. Cancer Research, Vol.65, No.(3), pp. 835839.

Ghiorzo, P., Ciotti, P., Mantelli, M., Heouaine, A., Queirolo, P., Rainero, M.L., Ferrari, C., Santi, P.L., De Marchi, R., Farris, A., Ajmar, F., Bruzzi, P., \& Bianchi-Scarra, G. (1999). Characterization of ligurian melanoma families and risk of occurrence of other neoplasia. International Journal of Cancer, Vol.83, No.(4), pp. 441-448.

Goldstein, A.M., Chan, M., Harland, M., Gillanders, E.M., Hayward, N.K., Avril, M.F., Azizi, E., Bianchi-Scarra, G., Bishop, D.T., Bressac-de Paillerets, B., Bruno, W., Calista, D., Cannon Albright, L.A., Demenais, F., Elder, D.E., Ghiorzo, P., Gruis, N.A., Hansson, J., Hogg, D., Holland, E.A., Kanetsky, P.A., Kefford, R.F., Landi, M.T., Lang, J., Leachman, S.A., MacKie, R.M., Magnusson, V., Mann, G.J., Niendorf, K., Newton, B.J., Palmer, J.M., Puig, S., Puig-Butille, J.A., de Snoo, F.A., Stark, M., Tsao, H., Tucker, M.A., Whitaker, L., \& Yakobson, E. (2006). High-risk melanoma susceptibility genes and pancreatic cancer, neural system tumors and uveal melanoma across GenoMEL. Cancer Research, Vol.66, No.(20), pp. 9818-9828.

Goldstein, A.M., Chan, M., Harland, M., Hayward, N.K., Demenais, F., Bishop, D.T., Azizi, E., Bergman, W., Bianchi-Scarra, G., Bruno, W., Calista, D., Albright, L.A., Chaudru, V., Chompret, A., Cuellar, F., Elder, D.E., Ghiorzo, P., Gillanders, E.M., Gruis, N.A., Hansson, J., Hogg, D., Holland, E.A., Kanetsky, P.A., Kefford, R.F., Landi, M.T., Lang, J., Leachman, S.A., MacKie, R.M., Magnusson, V., Mann, G.J., Bishop, J.N., Palmer, J.M., Puig, S., Puig-Butille, J.A., Stark, M., Tsao, H., Tucker, M.A., Whitaker, L., \& Yakobson, E. (2007). Features associated with germline CDKN2A mutations: a GenoMEL study of melanoma-prone families from three continents. Journal of Medical Genetics., Vol.44, No.(2), pp. 99-106. 
Goldstein, A.M., Fraser, M.C., Struewing, J.P., Hussussian, C.J., Ranade, K., Zametkin, D.P., Fontaine, L.S., Organic, S.M., Dracopoli, N.C., Clark, W.H., Jr., \& . (1995). Increased risk of pancreatic cancer in melanoma-prone kindreds with p16INK4 mutations. New England Journal of Medicine, Vol.333, No.(15), pp. 970-974.

Hashemi, J., Bendahl, P.O., Sandberg, T., Platz, A., Linder, S., Stierner, U., Olsson, H., Ingvar, C., Hansson, J., \& Borg, A. (2001). Haplotype analysis and age estimation of the 113insR CDKN2A founder mutation in Swedish melanoma families. Genes, Chromosomes \& Cancer, Vol.31, No.(2), pp. 107-116.

Holland, E.A., Beaton, S.C., Becker, T.M., Grulet, O.M., Peters, B.A., Rizos, H., Kefford, R.F., \& Mann, G.J. (1995). Analysis of the p16 gene, CDKN2, in 17 Australian melanoma kindreds. Oncogene, Vol.11, No.(11), pp. 2289-2294.

Kopf, A.W., Hellman, L.J., Rogers, G.S., Gross, D.F., Rigel, D.S., Friedman, R.J., Levenstein, M., Brown, J., Golomb, F.M., Roses, D.F., \& . (1986). Familial malignant melanoma. Journal of the American Medical Association, Vol.256, No.(14), pp. 1915-1919.

Lilischkis, R., Sarcevic, B., Kennedy, C., Warlters, A., \& Sutherland, R.L. (1996). Cancerassociated mis-sense and deletion mutations impair p16INK4 CDK inhibitory activity. International Journal of Cancer, Vol.66, No.(2), pp. 249-254.

Lynch, H.T., Brand, R.E., Hogg, D., Deters, C.A., Fusaro, R.M., Lynch, J.F., Liu, L., Knezetic, J., Lassam, N.J., Goggins, M., \& Kern, S. (2002). Phenotypic variation in eight extended CDKN2A germline mutation familial atypical multiple mole melanomapancreatic carcinoma-prone families: the familial atypical mole melanomapancreatic carcinoma syndrome. Cancer, Vol.94, No.(1), pp. 84-96.

MacKie, R.M. andrew, N., Lanyon, W.G., \& Connor, J.M. (1998). CDKN2A germline mutations in U.K. patients with familial melanoma and multiple primary melanomas. Journal of Investigative Dermatology, Vol.111, No.(2), pp. 269-272.

Monnerat, C., Chompret, A., Kannengiesser, C., Avril, M.F., Janin, N., Spatz, A., Guinebretiere, J.M., Marian, C., Barrois, M., Boitier, F., Lenoir, G.M., \& Bressac-de Paillerets, B. (2007). BRCA1, BRCA2, TP53 and CDKN2A germline mutations in patients with breast cancer and cutaneous melanoma. Familial Cancer, Vol.6, No.(4), pp. 453-461.

Monzon, J., Liu, L., Brill, H., Goldstein, A.M., Tucker, M.A., From, L., McLaughlin, J., Hogg, D., \& Lassam, N.J. (1998). CDKN2A mutations in multiple primary melanomas. New England Journal of Medicine, Vol.338, No.(13), pp. 879-887.

Nagore, E., Montoro, A., Garcia-Casado, Z., Botella-Estrada, R., Insa, A., Lluch, A., LopezGuerrero, J.A., \& Guillen, C. (2009). Germline mutations in CDKN2A are infrequent in female patients with melanoma and breast cancer. Melanoma Research, Vol.19, No.(4), pp. 211-214.

Prowse, A.H., Schultz, D.C., Guo, S., Vanderveer, L., Dangel, J., Bove, B., Cairns, P., Daly, M., \& Godwin, A.K. (2003). Identification of a splice acceptor site mutation in p16INK4A/p14ARF within a breast cancer, melanoma, neurofibroma prone kindred. Journal of Medical Genetics, Vol.40, No.(8), pp. e102.

Ranade, K., Hussussian, C.J., Sikorski, R.S., Varmus, H.E., Goldstein, A.M., Tucker, M.A., Serrano, M., Hannon, G.J., Beach, D., \& Dracopoli, N.C. (1995). Mutations associated with familial melanoma impair p16INK4 function. Nature Genetics, Vol.10, No.(1), pp. 114-116. 
Soufir, N., Avril, M.F., Chompret, A., Demenais, F., Bombled, J., Spatz, A., Stoppa-Lyonnet, D., Benard, J., \& Bressac-de Paillerets, B. (1998). Prevalence of p16 and CDK4 germline mutations in 48 melanoma-prone families in France. The French Familial Melanoma Study Group. Human Molecular Genetics, Vol.7, No.(2), pp. 209-216. 


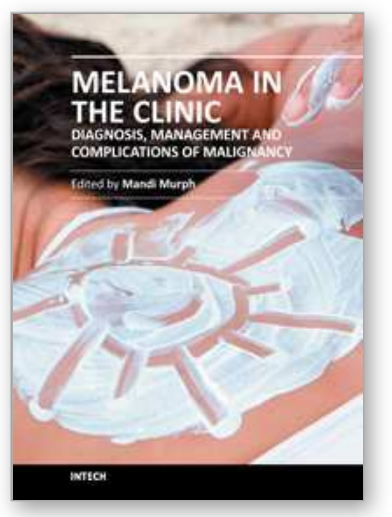

\section{Melanoma in the Clinic - Diagnosis, Management and Complications of Malignancy}

Edited by Prof. Mandi Murph

ISBN 978-953-307-571-6

Hard cover, 310 pages

Publisher InTech

Published online 23, August, 2011

Published in print edition August, 2011

This book provides an excellent overview of how melanoma is treated in the clinic. Since oncologists and clinicians across the globe contributed to this book, each area also explores the unique burdens that geographical areas experience from melanoma subtypes and how these are treated in different settings. It also includes several chapters that illustrate novel methods for diagnosing melanoma in the clinic using new technologies, which are likely to significantly improve outcomes. Several chapters cover surgical techniques and other present very rare or challenging clinical cases of melanoma and how these were treated. The book is geared towards informing clinicians and even patients how melanoma arises, what tools are available and which decisions need to be made by patients and their families in order to treat this devastating disease.

\section{How to reference}

In order to correctly reference this scholarly work, feel free to copy and paste the following:

Klára Balogh, Edina Nemes, Gabriella Uhercsák, Zsuzsanna Kahán, György Lázár, Gyula Farkas, Hilda Polyánka, Erika Kiss, Rolland Gyulai, Erika Varga, Erika Keresztné Határvölgyi, László Kaizer, Lajos Haracska, László Tiszlavicz, Lajos Kemény, Judit Oláh and Márta Széll (2011). Melanoma-Predisposing CDKN2A Mutations in Association with Breast Cancer: A Case-Study and Review of the Literature, Melanoma in the Clinic - Diagnosis, Management and Complications of Malignancy, Prof. Mandi Murph (Ed.), ISBN: 978-953307-571-6, InTech, Available from: http://www.intechopen.com/books/melanoma-in-the-clinic-diagnosismanagement-and-complications-of-malignancy/melanoma-predisposing-cdkn2a-mutations-in-association-withbreast-cancer-a-case-study-and-review-of-

\section{INTECH}

open science | open minds

\section{InTech Europe}

University Campus STeP Ri

Slavka Krautzeka 83/A

51000 Rijeka, Croatia

Phone: +385 (51) 770447

Fax: +385 (51) 686166

www.intechopen.com

\section{InTech China}

Unit 405, Office Block, Hotel Equatorial Shanghai

No.65, Yan An Road (West), Shanghai, 200040, China

中国上海市延安西路65号上海国际贵都大饭店办公楼405单元

Phone: +86-21-62489820

Fax: $+86-21-62489821$ 


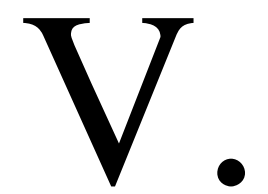




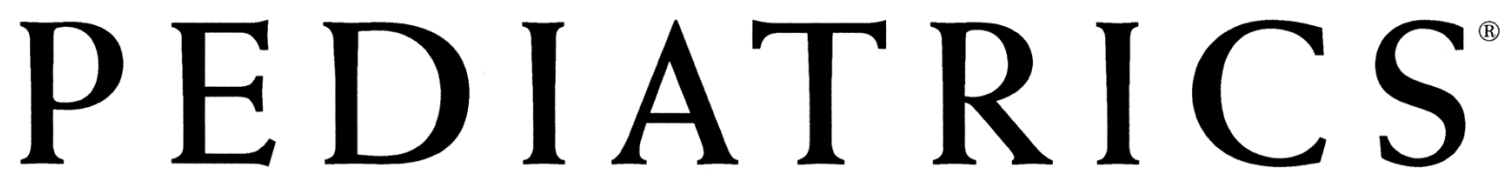

OFFICIAL JOURNAL OF THE AMERICAN ACADEMY OF PEDIATRICS

Neonatal Blue Light Phototherapy and Melanocytic Nevi: A Twin Study Zsanett Csoma, Edit Tóth-Molnár, Klára Balogh, Hilda Polyánka, Hajnalka Orvos, Henriette Ócsai, Lajos Kemény, Márta Széll and Judit Oláh

Pediatrics 2011;128;e856; originally published online September 19, 2011;

DOI: $10.1542 /$ peds.2011-0292

The online version of this article, along with updated information and services, is located on the World Wide Web at: http://pediatrics.aappublications.org/content/128/4/e856.full.html

PEDIATRICS is the official journal of the American Academy of Pediatrics. A monthly publication, it has been published continuously since 1948. PEDIATRICS is owned, published, and trademarked by the American Academy of Pediatrics, 141 Northwest Point Boulevard, Elk Grove Village, Illinois, 60007. Copyright (? 2011 by the American Academy of Pediatrics. All rights reserved. Print ISSN: 0031-4005. Online ISSN: 1098-4275.

\section{American Academy of Pediatrics}

DEDICATED TO THE HEALTH OF ALL CHILDREN ${ }^{\mathrm{m}}$ 


\section{Neonatal Blue Light Phototherapy and Melanocytic Nevi: A Twin Study}

WHAT'S KNOWN ON THIS SUBJECT: Neonatal blue light

phototherapy is an essential therapeutic tool in the management of neonatal jaundice to reduce the plasma concentration of bilirubin. Only a few and controversial data are available as to how blue light phototherapy influences melanocytic nevus development.

WHAT THIS STUDY ADDS: This is the first survey in the literature that allows the precise investigation of the impact of blue light phototherapy on cutaneous and uveal melanocytic nevus development with its possible genetic aspects in a homogenous study population of twins.

\section{abstract}

BACKGROUND: Neonatal blue light phototherapy (NBLP) has been widely and successfully used for the treatment of neonatal jaundice to reduce the plasma concentration of bilirubin and, hence, to prevent kernicterus. Only a few and controversial data are available in the literature as to how NBLP influences melanocytic nevus development.

OBJECTIVE: Our goal was to conduct a twin study with the aim of better understanding the role of NBLP in melanocytic nevus development. We also investigated the roles of other environmental and constitutional factors in nevus formation.

METHODS: Fifty-nine monozygotic and dizygotic twins were included in this cross-sectional study. One of the twin members received NBLP, and the other did not. A whole-body skin examination was performed to determine the density of melanocytic skin lesions. The prevalence of benign pigmented uveal lesions was evaluated during a detailed ophthalmologic examination. A standardized questionnaire was used to assess data relating to constitutional, sun-exposure, and other variables. To search for possible gene-environmental interactions involved in the appearance of pigmented lesions, the melanocortin 1 receptor variants and the $1439 \mathrm{~V}$ polymorphism of histidine ammonia-lyase genes were also determined in the enrolled twins.

RESULTS: NBLP was associated with a significantly higher prevalence of both cutaneous and uveal melanocytic lesions. No association was found between the examined gene polymorphisms and the number of pigmented alterations in the examined study group.

CONCLUSIONS: Our data suggest that NBLP could well be a risk factor for melanocytic nevus development. Phototherapy with blue-light lamps is a standard and essential therapeutic modality in neonatal care; therefore, additional in vivo and in vitro studies are necessary to establish its potential long-term adverse effects. Pediatrics 2011;128:e856-e864

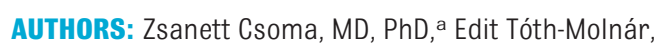
MD, PhD, ${ }^{b}$ Klára Balogh, MD, ${ }^{a}$ Hilda Polyánka, MSc, ${ }^{c}$ Hajnalka Orvos, MD, PhD, ${ }^{d}$ Henriette Ócsai, MD, ${ }^{a}$ Lajos Kemény, MD, DSc, ${ }^{a, c}$ Márta Széll, DSc, ${ }^{c}$ and Judit Oláh, MD, $\mathrm{PhD}^{\mathrm{a}}$

aDepartment of Dermatology and Allergology, ${ }^{\circ}$ Dermatological Research Group of the Hungarian Academy of Sciences, and ${ }^{d}$ Department of Obstetrics and Gynecology, University of Szeged, Szeged, Hungary; and ${ }^{b}$ Novotalex Ltd, Szeged, Hungary

\section{KEY WORDS}

neonatal blue light phototherapy, cutaneous melanocytic nevi, benign pigmented ocular lesions, MC1R and HAL polymorphisms

\section{ABBREVIATIONS}

CMN_common melanocytic nevus

CAMN — clinically atypical melanocytic nevus

BPUL—benign pigmented uveal lesion

NBLP—neonatal blue light phototherapy

MC1R-melanocortin 1 receptor

HAL-histidine ammonia-lyase

UCA —urocanic acid

IF-iris freckle

IN-iris nevus

$\mathrm{CN}$-choroidal nevus

SNP_single nucleotide polymorphism

RHC—red hair color

Dr Csoma designed and organized the study, participated in the clinical skin examinations, was responsible for attaining the oral sputum samples from the twin pairs, evaluated the results of dermatologic examinations, and wrote the main manuscript; Dr Tóth-Molnár performed all ophthalmologic examinations and wrote the manuscript; Dr Balogh was responsible for the sequence analysis of the MC1R gene; Ms Polyánka was responsible for preparation of genomic DNA samples, polymerase chain reactions, and purification of polymerase chain reaction products for sequence analysis; Dr Orvos was responsible for attaining data relating to the neonatal history of the participants and analyzed data; Dr Ócsai participated in the clinical skin examinations; Dr Kemény designed the study, analyzed data, and revised the manuscript; Dr Széll designed the genetic experiments, evaluated the results of genetic experiments, and wrote the manuscript; and Dr Oláh was the independent dermato-oncologist in the course of the entire survey who designed the study and revised the entire manuscript.

(Continued on last page) 
The number of people with large numbers of common (CMN) and clinically atypical (CAMN) melanocytic nevi has recently been continuously increasing. ${ }^{1}$ Numerous epidemiologic studies have revealed that the number of cutaneous nevi is affected by different constitutional, environmental, hormonal, and genetic factors. ${ }^{2-7}$ However, there are only a few reports on endogenous and exogenous factors that influence the development of benign pigmented uveal lesions (BPULs). The presence of large numbers of CMN and CAMN is a well-established independent phenotypic marker of a highly increased risk of the development of both cutaneous and uveal malignant melanoma, ${ }^{8-16}$ and the identification of any additional factor that might contribute to nevus formation is therefore of great importance. We previously investigated the prevalence of melanocytic nevi and associated factors in a large study population of adolescents and young adults, and we found that neonatal blue light phototherapy (NBLP) was associated with a significantly higher prevalence of CAMN. 17,18

NBLP is an essential therapeutic tool in the management of neonatal jaundice to reduce the plasma concentration of bilirubin and hence to prevent kernicterus. ${ }^{19-21}$ Its potential acute, shortterm adverse effects are well known and can be adequately treated in neonatal practice. Much less is known on its long-term adverse effects. Of these, only a few and controversial data are available as to how NBLP influences melanocytic nevus development,,22-24 and there is a lack of surveys in the literature as concerns pigmented ocular alterations in such patients.

On the basis of our previous results, our goal was to conduct a twins study with the aim of a better understanding of the role of NBLP in melanocytic nevus development. We also investigated the roles of other environmental and constitutional factors in nevus formation.

To understand the complex nature of melanocytic nevus development, it is of pivotal interest to investigate the geneenvironment interactions that cause this melanoma-predisposing condition. It is well established that variants of the melanocortin 1 receptor (MC1R) gene are associated with the combination of red hair, freckling, and sun sensitivity. ${ }^{25-27}$ Histidase, encoded by the HAL (histidine ammonia-lyase) gene, catabolizes the amino acid L-histidine to trans-urocanic acid (trans-UCA); then, on UV-B induction, trans-UCA photoisomerizes to cis-UCA, which plays a basic role in UV-induced immunosuppression. ${ }^{28-30}$ It has recently been demonstrated ${ }^{31}$ that the interaction of sunburn with the $1439 \mathrm{~V}$ polymorphism of $\mathrm{HAL}$ is associated with nonmelanoma skin cancers such as basal cell carcinoma and squamous cell carcinoma. To search for possible geneenvironmental interactions involved in the appearance of pigmented lesions, we determined the MC1R variants and the $1439 \mathrm{~V}$ polymorphism of HAL in the enrolled twins.

\section{METHODS}

\section{Patients}

Fifty-eight pairs of twins and 1 set of triplets of white origin, aged 3 to 30 years, were included in our study, which was performed between January 5, 2008, and April 12, 2008, in the Department of Dermatology and Allergology at the University of Szeged (Szeged, Hungary). The distribution of the participating twin pairs was as follows: 15 monozygotic pairs (7 female and 8 male pairs), 11 dizygotic female pairs, 11 dizygotic male pairs, 21 dizygotic pairs of different genders, and 1 dizygotic female triplet. After approval and permission had been obtained from the institutional review board of Albert Szent-Györgyi Medidal Center at the University of Szeged, all the participants or their parents gave their written consent before the start of the survey. As we put special emphasis on the investigation of the effect of NBLP on nevus development, we enrolled monozygotic and dizygotic twin pairs, where 1 of the twins had received phototherapy for neonatal jaundice and the other had not. Data relating to the neonatal history of the subjects (prematurity, icterus, and NBLP) were obtained from the official neonatal medical charts.

The study was based on 4 major elements: a clinical skin examination, a standardized questionnaire, an ophthalmologic examination, and DNA sampling. Neither the dermatologists nor the ophthalmologist knew whether the investigated subjects had received NBLP.

\section{Skin Examinations}

All twin pairs underwent a wholebody skin examination, excluding the scalp and the anogenital area. Melanocytic nevi were counted as in the standardized international protocol according to English et al. ${ }^{32}$ Pigmented lesions with the morphologic features of CMN, CAMN, congenital melanocytic nevi, blue nevi, Spitz nevi, nevi spili, halo nevi, lentigines, and café-au-lait macules were counted separately, and the presence of freckles was also recorded in each subject.

\section{Interview}

After the clinical skin examinations, a standardized questionnaire was completed by all the participants or the accompanying parents. The questionnaire sought information on sunbathing habits, sun protection methods, other sun-exposure variables, and a family history of a large number of melanocytic nevi, melanoma, or nonmelanoma skin cancers. Pigmentary 
traits such as eye color, hair color, skin color, and skin phototype were evaluated in each subject. Skin phototype was assessed on the Fitzpatrick scale, which is based on a person's reaction to 30 minutes of midday sunlight for the first time in the summer (I $=$ always burns, never tans; $\|=$ always burns, sometimes tans; $I I I=$ sometimes burns, always tans; IV = never burns, always tans). Skin color was described on a 3-grade scale (dark, medium, or fair).

\section{Ophthalmologic Examination}

Detailed ophthalmologic examinations were conducted, including slit-lamp biomicroscopic examination of the anterior segment without dilation of the pupil (using the Inami L-0189 slit-lamp, Inami \& Co. Ltd., Tokyo, Japan) and applanation tonometry (using the Inami L-5130 applanation tonometer, Inami \& Co. Ltd., Tokyo, Japan). Complete indirect ophthalmoscopic examinations of the fundi were performed after maximal dilation of the pupil with cyclopentolate $0.5 \%$, using the Heine 0mega 100 (Heine 0ptotechnik GmbH \& Co. KG., Herrsching, Germany) indirect ophthalmoscope.

For all participants, a standardized form was used to record the iris color, the presence and location of conjunctival nevi, the numbers and distribution of iris freckles (IF), iris nevi (IN), choroidal nevi (CHN), or any pigmented lesions of other ocular structures. Lesions identified were defined according to the Shields system of classification. ${ }^{33}$ Exclusion criteria were (1) media opacity that precluded examination of the choroid, (2) iris heterochromia, (3) disorders or medication that could alter the iris color (eg, iris neovascularization, anamnestic uveitis or ocular injury, the use of prostaglandin analogue eye drops), and (4) ocular or oculodermal melanocytosis or neurofibromatosis as known factors predisposing to ocular nevus formation.
TABLE 1 Prevalence of Common and Clinically Atypical Melanocytic Nevi According to Age Groups Among Twin Pairs

\begin{tabular}{lcccc}
\hline \multicolumn{1}{c}{ Age } & $\begin{array}{c}\text { No. of } \\
\text { Subjects }\end{array}$ & $\begin{array}{c}\text { Median No. of CMN } \\
\text { (Lower, Upper } \\
\text { Quartile) }\end{array}$ & $\begin{array}{c}\text { Median No. of CAMN } \\
\text { (Lower, Upper } \\
\text { Quartile) }\end{array}$ & $\begin{array}{c}\text { Median No. of Melanocytic } \\
\text { Nevi (CMN + CAMN) } \\
\text { (Lower, Upper Quartile) }\end{array}$ \\
\hline $\begin{array}{c}\text { Monozygtic twin pairs } \\
(n=30)\end{array}$ & & & \\
$3-6$ y & 4 & $1(0.5-2)$ & $0(0-0)$ & $1(0.5-2)$ \\
$7-10$ y & 6 & $3.5(3-6)$ & $0(0-0)$ & $4(3-6)$ \\
$11-14$ y & 8 & $12.5(8.5-26.5)$ & $2.5(0-3.5)$ & $15(10-28.5)$ \\
$15-18$ y & 2 & $3(3-7)$ & $0(0-1)$ & $4(3-7)$ \\
$19-22$ y & 2 & $11.5(11-12)$ & $0.5(0-1)$ & $12(11-13)$ \\
$23-26$ y & 6 & $12(9-21)$ & $1(0-3)$ & $14(9-22)$ \\
$27-30$ y & 2 & $7.5(3-12)$ & $8(3-13)$ & \\
Dizygotic twin pairs & & & & $2(6-25)$ \\
$(n=89)$ & & & $0(0-0)$ & $9(6-14.5)$ \\
$3-6$ y & 18 & $2(1-4)$ & $0(0-1)$ & $7(4-10)$ \\
$7-10$ y & 20 & $9(5.5-135)$ & $1(0-2)$ & $22(12-33)$ \\
$11-14$ y & 14 & $6(3-9)$ & $3(1-9)$ & $25.5(6.5-40)$ \\
$15-18$ y & 11 & $21(10-23)$ & $2.5(0.5-5)$ & $19(9-36)$ \\
$19-22$ y & 12 & $22.5(6.5-34)$ & $2(0-2)$ & $30.5(15.5-36.5)$ \\
$23-26$ y & 6 & $17(8-34)$ & $1(0-3.5)$ & \\
$27-30$ y & 8 & $29.5(13.5-35)$ & & \\
\hline
\end{tabular}

\section{Determination of MC1R Gene \\ Variants and the I439V \\ Polymorphism of the HAL Gene}

Genomic DNA was isolated from oral sputum sample of monozygotic and dizygotic twin pairs and triplets using BioRobot EZ1 and Qiagen EZ1 DNA Investigator Kit (Qiagen, Hilden, Germany). Determination of MC1R gene variants were performed by using the full-length sequencing of the gene as described previously, ${ }^{34}$ and the $1439 \mathrm{~V}$ polymorphism of HAL gene was investigated by a method devised by Welsch et al. ${ }^{31}$

TABLE 2 Prevalence of Other Pigmented Skin Lesions Among Monozygotic and Dizygotic Twin Pairs $(N=119)$

\begin{tabular}{lcc}
\hline \multicolumn{1}{c}{ Lesion } & $\begin{array}{c}\text { No. of Subjects } \\
\text { With Lesions }\end{array}$ & $\begin{array}{c}\text { No. of } \\
\text { Lesions }\end{array}$ \\
\hline Congenital nevus & 19 & 28 \\
Café au lait macules & 20 & 24 \\
Nevus spilus & 2 & 2 \\
Becker nevus & 1 & 1 \\
\hline
\end{tabular}

\section{Statistical Analyses}

The correlations between the prevalence of melanocytic nevi and possible endogenous and exogenous risk factors were initially assessed univariately by using the nonparametric Kruskal-Wallis test, and the Wilcoxon signed rank test. The Spearman rank correlation test was conducted to evaluate the correlations between the numbers of CMN, CAMN, and BPUL. All $P$ values calculated were 2-sided, and a significance level of 0.05 was assumed. All variables were entered into multivariate logistic or linear regression analyses to evaluate the simultaneous effect of different factors on melanocytic nevus development. For pigmented cutaneous lesions, the dependent variable was the number of nevi with a logarithmic transformation; the natural logarithm of the nevus count demon-
TABLE 3 Summary of Statistical Analysis (Wilcoxon Signed Rank Test, $P$ Values) for the Difference in Prevalence of Melanocytic Nevi Between Blue Light-Exposed and Nonexposed Twin Members $(N=119)$

\begin{tabular}{lccc}
\hline \multicolumn{1}{c}{ Subjects } & CMN & CAMN & All Melanocytic Nevi \\
\hline Monozygotic twin pairs $(n=15)$ & .025 & .017 & .014 \\
Dizygotic twin pairs $(n=44)$ & .042 & .12 & .038 \\
All twin pairs $(n=59)$ & .010 & .016 & .005 \\
\hline
\end{tabular}


strated a normal distribution with the Kolmogorov-Smirnov 1-sample test, and multivariate linear regression analysis was performed. The number of BPUL did not show normal distribution by the Kolmogorov-Smirnov test, and because of the high numbers of 0 values in the survey, multivariate logistic regression analysis was conducted. Statistical analyses were performed with SPSS 15.0 (SPSS Inc, Chicago, IL).

\section{RESULTS}

\section{Skin Examinations}

The prevalence of CMN and CAMN is presented by median nevus counts with interquartile ranges in different age groups in Table 1. The number of CAMN was strongly associated with the prevalence of CMN (the Spearman rank correlation test, $r=0.589$ ). The prevalence of other pigmented cutaneous lesions is presented in Table 2.

On univariate analysis, NBLP was associated with a significantly higher prevalence of both CMN and CAMN in the examined twin pairs. When the analysis was focused separately on the monozygotic and the dizygotic twin pairs, a statistically significant difference in the number of nevi was still observed between the exposed and nonexposed subjects in the monozygotic twins. In the case of dizygotic twin pairs, the number of $\mathrm{CMN}$ and the whole number of melanocytic nevi differed in a statistically significant manner between the treated and the untreated twin members (Wilcoxon signed ranktest; Table 3).

The associations between gender, constitutional and sun-exposure variables, and the prevalence of melanocytic nevi with the nonparametric Kruskall-Wallis test are presented in Table 4. In multivariate linear regression analysis, the number of melanocytic nevi was significantly and independently associated with age, with the number of summer holidays beside the sea in the Mediterranean or in
TABLE 4 Associations Between Gender, Constitutional, and Sun-Exposure Variables and the Prevalence of Melanocytic Nevi Among Monozygotic and Dizygotic Twin Pairs $(N=119)$ (Nonparametric Kruskall-Wallis Test)

\begin{tabular}{|c|c|c|c|}
\hline Factors & $n$ & $\begin{array}{c}\text { Median No. of } \\
\text { Melanocytic Nevi }\end{array}$ & $P$ \\
\hline \multicolumn{4}{|l|}{ Gender } \\
\hline Male & 59 & $7(4-16)$ & \\
\hline Female & 60 & $9(4-21)$ & .46 \\
\hline \multicolumn{4}{|l|}{ Eye color } \\
\hline Brown & 57 & $6(3-15.5)$ & \\
\hline Hazel, greenish-brown & 12 & $8(5-30.75)$ & \\
\hline Green, gray, blue & 50 & $12.5(4-26.25)$ & .049 \\
\hline \multicolumn{4}{|l|}{ Hair color } \\
\hline Black, dark-brown & 25 & $12(5.5-30.5)$ & \\
\hline Medium-brown, light-brown & 81 & $7(4-17.5)$ & \\
\hline Blond & 13 & $12(2-19.5)$ & .33 \\
\hline \multicolumn{4}{|l|}{ Skin color } \\
\hline Dark, medium & 62 & $8(3-20.25)$ & \\
\hline Fair & 57 & $9(4-21)$ & .46 \\
\hline \multicolumn{4}{|l|}{ Skin phototype } \\
\hline$|-| \mid$ & 32 & $8(4-13.25)$ & \\
\hline III-IV & 87 & $9(4-23)$ & .36 \\
\hline \multicolumn{4}{|l|}{ Frequency of use of sunscreens } \\
\hline Never & 11 & $8(3-13)$ & \\
\hline Occasionally & 43 & $9(4-24)$ & \\
\hline Always at the beginning of the summer, then occasionally & 31 & $10(6-17)$ & \\
\hline Regularly & 34 & $5(3-14)$ & .12 \\
\hline \multicolumn{4}{|l|}{ Duration of use of sunscreens } \\
\hline Never & 18 & $8(3.75-13.75)$ & \\
\hline $1-5 y$ & 47 & $9(2-16)$ & \\
\hline $6-10 y$ & 30 & $7.5(4-18.5)$ & \\
\hline $10-20 \mathrm{y}$ & 24 & $17.5(6-32.75)$ & .048 \\
\hline \multicolumn{4}{|l|}{ SPF } \\
\hline 0 & 11 & $8(3-13)$ & \\
\hline $1-10$ & 20 & $18(8.25-32.25)$ & \\
\hline $10-20$ & 43 & $13(4-24)$ & \\
\hline$>20$ & 45 & $6(2.5-10)$ & \\
\hline \multicolumn{4}{|l|}{ No. of severe painful sunburns during childhood } \\
\hline 0 & 62 & $6(3-15.25)$ & \\
\hline $1-2$ & 46 & $9(4-24.25)$ & \\
\hline $3-5$ & 11 & $16(11-27)$ & 0.014 \\
\hline \multicolumn{4}{|l|}{ No. of severe painful sunburns during adolescence } \\
\hline 0 & 39 & $10(5-30)$ & \\
\hline $1-2$ & 21 & $24(13.5-33)$ & \\
\hline $3-5$ & 4 & $17.5(9.5-51.75)$ & 0.043 \\
\hline \multicolumn{4}{|l|}{ No. of severe painful sunburns during adulthood } \\
\hline 0 & 25 & $17(7-35.5)$ & \\
\hline $1-2$ & 13 & $14(11.5-30.5)$ & \\
\hline $3-5$ & 2 & $15(3-27)$ & 0.69 \\
\hline \multicolumn{4}{|l|}{$\begin{array}{l}\text { Frequency of sunbathing episodes between April and } \\
\text { September }\end{array}$} \\
\hline 0 & 17 & $9(4-21)$ & \\
\hline $1-10$ & 32 & $8(5-17.75)$ & \\
\hline $10-20$ & 19 & $17(8-35)$ & \\
\hline$>20$ & 47 & $6(3-16)$ & 0.020 \\
\hline \multicolumn{4}{|l|}{ Duration of 1 sunbathing episode } \\
\hline$<30 \min$ & 23 & $7(3-13)$ & \\
\hline $30 \mathrm{~min}$ to $1 \mathrm{~h}$ & 31 & $17(7-33)$ & \\
\hline $1-3 \mathrm{~h}$ & 41 & $6(2.5-17.5)$ & \\
\hline$>3 h$ & 22 & $9(5.75-14.5)$ & 0.005 \\
\hline \multicolumn{4}{|l|}{$\begin{array}{l}\text { No. of days per week when }>4 \mathrm{~h} \text { was spent outdoors during } \\
\text { childhood }\end{array}$} \\
\hline $0-1$ & 17 & $5(2.5-12.5)$ & \\
\hline $2-3$ & 44 & $11.5(4.5-26.75)$ & \\
\hline $4-5$ & 31 & $13(4-21)$ & \\
\hline $6-7$ & 27 & $6(3-10)$ & 0.08 \\
\hline
\end{tabular}


TABLE 4 Continued

\begin{tabular}{|c|c|c|c|c|}
\hline & Factors & $n$ & $\begin{array}{l}\text { Median No. of } \\
\text { Melanocytic Nevi }\end{array}$ & $P$ \\
\hline \multicolumn{5}{|c|}{$\begin{array}{l}\text { No. of days per week when }>4 \mathrm{~h} \text { was spent outdoors during } \\
\text { adolescence }\end{array}$} \\
\hline $0-1$ & & 11 & $9(4-32)$ & \\
\hline $2-3$ & & 22 & $21.5(13.5-33.5)$ & \\
\hline $4-5$ & & 23 & $13(7-30)$ & \\
\hline $6-7$ & & 6 & $17.5(7.5-33.75)$ & 0.33 \\
\hline \multicolumn{5}{|c|}{$\begin{array}{l}\text { No. of days per week when }>4 \text { h was spent outdoors during } \\
\text { adulthood }\end{array}$} \\
\hline $0-1$ & & 6 & $20.5(5-66.25)$ & \\
\hline $2-3$ & & 13 & $30(9-38.5)$ & \\
\hline $4-5$ & & 10 & $16(11-26.25)$ & \\
\hline $6-7$ & & 8 & $10.5(6.5-33.25)$ & 0.67 \\
\hline \multicolumn{5}{|c|}{$\begin{array}{l}\text { No. of summer holidays beside the sea in the Mediterranean } \\
\text { or in a subtropical or tropical climate }\end{array}$} \\
\hline 0 & & 63 & $8(3-14)$ & \\
\hline $1-2$ & & 25 & $6(4-16)$ & \\
\hline $3-4$ & & 14 & $13(4-24.25)$ & \\
\hline $5-7$ & & 14 & $25(9-43.75)$ & \\
\hline$>8$ & & 3 & $33(6-35)$ & 0.008 \\
\hline \multicolumn{5}{|l|}{ Use of sunbeds } \\
\hline Never & & 106 & $8(4-17.25)$ & \\
\hline Occasionally & & 10 & $20(11.5-30.75)$ & \\
\hline Regularly & & 3 & $17(9-109)$ & 0.013 \\
\hline \multicolumn{5}{|c|}{ Family history of large numbers of melanocytic nevi } \\
\hline No & & 52 & $9.5(4-21)$ & \\
\hline Yes & & 56 & $7.5(3.25-22.5)$ & 0.49 \\
\hline
\end{tabular}

a subtropical or a tropical climate, and with a history of NBLP (see Table 5).

\section{Ophthalmologic Examination}

The following pigmented ocular lesions were documented during the ophthalmologic examination: IF in 18 subjects; IN in 2 subjects; and CHN in 3 subjects (Table 6). A statistically significant correlation was found between the prevalence of BPUL and the number of CAMN (the Spearman rank correlation test, $r=0362$ ).

When all of the melanocytic ocular findings were examined together,
TABLE 6 Prevalence of Benign Pigmented Ocular Lesions Among Monozygotic and Dizygotic Twin Pairs $(N=113)$

\begin{tabular}{lcc}
\hline Lesion & $\begin{array}{c}\text { No. of Subjects } \\
\text { With Lesions }\end{array}$ & $\begin{array}{c}\text { No. of } \\
\text { Lesions }\end{array}$ \\
\hline IN & 2 & 5 \\
CN & 3 & 4 \\
IF & 18 & 123 \\
\hline
\end{tabular}

TABLE 7 Prevalence of Benign Pigmented 0cular Lesions in Blue Light-Exposed and Nonexposed Twin Members (Wilcoxon Signed Rank Test)

\begin{tabular}{lccc}
\hline Lesion & $\begin{array}{c}\text { No. of Lesions } \\
\text { in Subjects } \\
\text { With no NBLP }\end{array}$ & $\begin{array}{c}\text { No. of Lesions } \\
\text { in Subjects }\end{array}$ & $P$ \\
With NBLP & \\
\hline IN & 1 & 4 & NA $^{a}$ \\
CHN & 0 & 4 & NA $^{a}$ \\
IF & 18 & 105 & .009 \\
IN + CHN + IF & 19 & 114 & .006 \\
\hline a In view of the low rate of occurrence of uveal nevi in the \\
study population, statistical analyses were not possible.
\end{tabular}

gression analysis confirmed the significant correlation between NBLP and the prevalence of BPUL (Table 9).

\section{MC1R and HAL Polymorphisms}

Genetic analysis was performed on 75 subjects (36 twin pairs and 1 set of triplets). For this analysis, we selected twin pairs in whom the difference in nevus count was significant. Within this selected subgroup, there was an unequivocal association of NBLP both with the CMN count ( $P=.010$; Wilcoxon signed ranks test) and with the CAMN count $(0.055$, Wilcoxon signed ranks test). When the number of cutaneous pigmented lesions (CMN + CAMN) was analyzed as a function of NBLP, a highly significant effect was detected $(P=$

TABLE 5 Factors Associated With the Prevalence of Melanocytic Nevi: Results of Multivariate Linear Regression Analysis

\begin{tabular}{|c|c|c|c|c|c|}
\hline \multirow[t]{2}{*}{ Variable } & \multirow{2}{*}{$\begin{array}{l}\text { Unstandardized } \\
\text { Coefficients, B }\end{array}$} & \multirow{2}{*}{$\begin{array}{l}\text { Standardized } \\
\text { Coefficients, } \beta\end{array}$} & \multirow[t]{2}{*}{$P$} & \multicolumn{2}{|c|}{ 95\% Confidence Limits for B } \\
\hline & & & & Lower Bound & Upper Bound \\
\hline Age & 0.076 & 0.503 & .000 & 0.051 & 0.101 \\
\hline $\begin{array}{l}\text { No. of summer holidays beside the sea in the Mediterranean, or in a } \\
\text { subtropical or tropical climate }\end{array}$ & 0.172 & 0.178 & .035 & 0.012 & 0.332 \\
\hline NBLP & 0.177 & 0.158 & .047 & 0.003 & 0.352 \\
\hline
\end{tabular}

The multivariate linear regression (stepwise method) model included gender, eye color, hair color, skin color, skin phototype, the frequency of use of sunscreens, a history of severe painful sunburns, the frequency and duration of sunbathing, the number of days per week when $>4$ hours was spent outdoors, the number of summer holidays beside the sea in the Mediterranean, or in a subtropical or tropical climate, the use of sunbeds, a family history of large numbers of melanocytic nevi, a history of NBLP, and age. The number of melanocytic nevi did not show normal distribution by the Kolmogorov-Smirnov test. Multivariate linear regression was therefore performed on the natural logarithm of the nevus count. 
.006; Wilcoxon signed ranks test). Our sequencing survey detected $9 \mathrm{MC} 1 \mathrm{R}$ polymorphisms: the synonymous T413T SNP (single nucleotide polymorphism) in heterozygous form in 3 subjects, the rare $1120 \mathrm{~T}$ polymorphism in a twin pair as a heterozygous variant, 2 red hair color (RHC) variants (R151C and R160W), 4 frequent non-RHC variants (V60L, V92M, I155T, and W1630), and a new variant, W169R, in 1 subject.

Statistical analyses were performed with various groupings of the MC1R polymorphisms: (1) the presence of either of the RHC alleles (R151C and R160W) was considered; (2) the presence of any of the most frequent 6 MC1R polymorphisms (V60L, V92M, R151C, R160W, W1630, and I155T = SNP6) was considered; (3) the presence of any of the SNP6 group and the rare 1120 T polymorphism (= SNP7) was considered; or (4) the presence of either of SNP7 and the newly identified W169R polymorphism (= SNP8) was considered. It was unambiguously demonstrated that the MC1R polymorphisms have a significant effect on the skin type of the examined twins (R151C and R160W, $P=.001$; SNP6, $P=.013$; SNP7, $P=.013$; SNP8, $P=.023$ ), but the I439V HAL polymorphism did not exhibit any association with the skin type in our study population.

The effect of the polymorphisms on the numbers of pigmented skin lesions and the presence of pigmented uveal lesions was assessed by using univariate and multivariate statistical analyses. Neither the univariate (MannWhitney test; Table 10) nor the multivariate (analysis of variance; Table 11) analysis revealed any effects of the studied polymorphisms on the skin and uveal pigmented lesions.

\section{DISCUSSION}

Physiologic jaundice develops in a notably high proportion of otherwise healthy newborn infants as a result of
TABLE 8 Associations Between Gender, Constitutional, and Sun-Exposure Variables and the Prevalence of Benign Pigmented Ocular Lesions Among Monozygotic and Dizygotic Twin Pairs $(N=113)$ (Nonparametric Kruskall-Wallis Test)

\begin{tabular}{|c|c|c|}
\hline Factors & No. of Subjects & $P$ \\
\hline \multicolumn{3}{|l|}{ Gender } \\
\hline Male & $66 / 56$ & \\
\hline Female & $66 / 57$ & .66 \\
\hline \multicolumn{3}{|l|}{ Eye color } \\
\hline Brown & $63 / 51$ & \\
\hline Hazel, greenish-brown & $34 / 11$ & \\
\hline Green, gray, blue & $35 / 51$ & .19 \\
\hline \multicolumn{3}{|l|}{ Hair color } \\
\hline Black, dark-brown & $18 / 21$ & \\
\hline Medium-brown, light-brown & $89 / 80$ & \\
\hline Blond & $25 / 12$ & .71 \\
\hline \multicolumn{3}{|l|}{ Skin color } \\
\hline Dark, medium & $49 / 58$ & \\
\hline Fair & $83 / 55$ & .47 \\
\hline \multicolumn{3}{|l|}{ Skin phototype } \\
\hline $1-||$ & $59 / 31$ & \\
\hline III-IV & $73 / 82$ & .33 \\
\hline \multicolumn{3}{|c|}{ No. of severe painful sunburns during childhood } \\
\hline 0 & $49 / 59$ & \\
\hline $1-2$ & $80 / 44$ & \\
\hline $3-5$ & $3 / 10$ & .042 \\
\hline \multicolumn{3}{|c|}{ No. of severe painful sunburns during adolescence } \\
\hline 0 & $60 / 34$ & \\
\hline $1-2$ & $24 / 21$ & \\
\hline $3-5$ & $0 / 3$ & .61 \\
\hline \multicolumn{3}{|c|}{ No. of severe painful sunburns during adulthood } \\
\hline 0 & $24 / 20$ & \\
\hline $1-2$ & $1 / 11$ & \\
\hline $3-5$ & $7 / 3$ & .09 \\
\hline \multicolumn{3}{|c|}{ Frequency of sunbathing episodes between April and September } \\
\hline 0 & $0 / 17$ & \\
\hline $1-10$ & $43 / 31$ & \\
\hline $10-20$ & $40 / 16$ & \\
\hline$>20$ & $44 / 45$ & .040 \\
\hline \multicolumn{3}{|l|}{ Duration of 1 sunbathing episode } \\
\hline$<30 \min$ & $24 / 24$ & \\
\hline $30 \mathrm{~min}-1 \mathrm{~h}$ & $30 / 31$ & \\
\hline $1-3 \mathrm{~h}$ & $62 / 37$ & \\
\hline$>3 h$ & $14 / 19$ & .16 \\
\hline \multicolumn{3}{|c|}{ No. of days per week when $>4 \mathrm{~h}$ was spent outdoors during childhood } \\
\hline $0-1$ & $12 / 17$ & \\
\hline $2-3$ & $70 / 43$ & \\
\hline $4-5$ & $18 / 27$ & \\
\hline $6-7$ & $32 / 26$ & .45 \\
\hline \multicolumn{3}{|c|}{ No. of days per week when $>4 \mathrm{~h}$ was spent outdoors during adolescence } \\
\hline $0-1$ & $12 / 7$ & \\
\hline $2-3$ & $24 / 23$ & \\
\hline $4-5$ & $26 / 21$ & \\
\hline $6-7$ & $14 / 6$ & .45 \\
\hline \multicolumn{3}{|c|}{ No. of days per week when $>4 \mathrm{~h}$ was spent outdoors during adulthood } \\
\hline $0-1$ & $2 / 6$ & \\
\hline $2-3$ & $16 / 9$ & \\
\hline $4-5$ & $0 / 9$ & \\
\hline $6-7$ & $14 / 8$ & .21 \\
\hline \multicolumn{3}{|c|}{$\begin{array}{l}\text { No. of summer holidays beside the sea in the Mediterranean or in a } \\
\text { subtropical or tropical climate }\end{array}$} \\
\hline 0 & $58 / 59$ & \\
\hline $1-2$ & $41 / 24$ & \\
\hline $3-4$ & $21 / 15$ & \\
\hline $5-7$ & $12 / 13$ & \\
\hline$>8$ & $0 / 2$ & .88 \\
\hline
\end{tabular}


TABLE 8 Continued

\begin{tabular}{|c|c|c|}
\hline Factors & No. of Subjects & $P$ \\
\hline \multicolumn{3}{|l|}{ Use of sunbeds } \\
\hline Never & $125 / 100$ & \\
\hline 0ccasionally & $5 / 11$ & \\
\hline Regularly & $2 / 2$ & .64 \\
\hline \multicolumn{3}{|c|}{ Family history of large numbers of melanocytic nevi } \\
\hline No & $62 / 53$ & \\
\hline Yes & $70 / 50$ & .86 \\
\hline
\end{tabular}

TABLE 9 Factors Associated With the Prevalence of Benign Pigmented Ocular Lesions: Results of Multivariate Logistic Regression Analysis

\begin{tabular}{ccccc}
\hline & $P$ & Odds & & \multicolumn{2}{l}{$95 \%$ Confidence } \\
& & Ratio & & \multicolumn{2}{c}{ Limits for 0dds } \\
& & & \multicolumn{2}{c}{ Ratio } \\
\cline { 3 - 5 } & & & Lower & Upper \\
\hline Blue light & 0.001 & 3.778 & 1.694 & 8.423 \\
\hline
\end{tabular}

$\mathrm{Cl}$ indicates confidence interval. The multivariate logistic regression (stepwise method) model included gender, eye color, hair color, skin color, skin phototype, the frequency of use of sunscreens, a history of severe painful sunburns, the frequency and duration of sunbathing, the number of days per week when $>4$ hours was spent outdoors, the number of summer holidays beside the sea in the Mediterranean or in a subtropical or tropical climate, the use of sunbeds, a family history of large numbers of melanocytic nevi, a history of NBLP, and age. The number of ocular lesions did not show normal distribution by the Kolmogorov-Smirnov test, and due to the high numbers of 0 values in the survey, multivariate logistic regression was performed.

excessive bilirubin formation. Without adequate treatment, the lipid-soluble, unconjugated bilirubin crosses the blood-brain barrier. The deposition of bilirubin in the basal ganglia and brainstem nuclei can result in very severe, permanent central nervous system damage (ie, acute and chronic bilirubin encephalopathy). Phototherapy,

applying the clinically most effective blue emission spectrum (425-475 $\mathrm{nm})$, has been widely and successfully used for the treatment of neonatal jaundice to reduce the plasma concentration of bilirubin and hence to prevent kernicterus. ${ }^{19-21}$

So far, only a few and contradictory data are available as to how NBLP influences melanocytic nevus development. 17,18,22-24,35 Our results reveal a significantly higher prevalence of cutaneous melanocytic nevi among twin members with a history of NBLP. A standardized questionnaire was used to assess the data relating to constitutional, sun-exposure, and other variables. These factors proved to be very consistent in the examined monozygotic twin pairs. The phenotypic characteristics of the dizygotic twins were partly different, but the environmental impacts were very similar until adulthood. The emission spectrum of the blue light lamps used in Hungary is between 370 and $600 \mathrm{~nm}$ (maximum: 450 $\mathrm{nm}$ ). Approximately $0.3 \%$ of the emitted light comprises UVA radiation. The
TABLE 10 Summary of Statistical Analyses (Mann-Whitney Test; $P$ Values) for the Gene Polymorphism Skin/0cular Pigmented Lesions Associations

\begin{tabular}{lcccccc}
\hline \multicolumn{1}{c}{ Variable } & $\begin{array}{c}\text { Common } \\
\text { CMN }\end{array}$ & CAMN & $\begin{array}{c}\text { All Melanocytic Nevi } \\
\text { of the Skin } \\
\text { (CMN + CAMN) }\end{array}$ & IF + CHN & IF + IN + CHN \\
\hline HAL & .81 & .15 & .63 & .9 & .96 & .86 \\
R151C_R160W & .99 & .62 & .92 & .53 & .76 & .62 \\
SNP6 & .95 & .71 & .91 & .7 & .74 & .76 \\
SNP7 & .95 & .71 & .91 & .7 & .74 & .76 \\
SNP8 & .65 & .97 & .78 & .79 & .68 & .86 \\
\hline
\end{tabular}

HAL indicates I439V polymorphism of the histidase gene; R151C_R160W, the presence of either of the RHC alleles (R151C and R160W) of MC1R gene; SNP6, the presence of any of the most frequent 6 MC1R polymorphisms (V60L, V92M, R151C, R160W, W163Q, and I155T); SNP7, the presence of any of the SNP6 group and the rare I120T polymorphism; SNP8, the presence of either of SNP7 and the newly identified W169R polymorphism.
TABLE 11 Summary of Multivariate Statistical Analyses

\begin{tabular}{ccc}
\hline Variable & $\begin{array}{c}\text { Pigmented } \\
\text { Lesions of the } \\
\text { Skin } \\
\text { (CMN + CAMN) }\end{array}$ & $\begin{array}{c}\text { Pigmented } \\
\text { Ocular Lesions } \\
(\text { IF }+ \text { IN }+ \text { CHN })^{\mathrm{b}}\end{array}$ \\
\hline HAL & .62 & .88 \\
Blue light & .011 & .010 \\
Age & .000 & .4 \\
R151C_R160W & .35 & .56 \\
Blue light & .05 & .010 \\
Age & .000 & .45 \\
SNP6 & .82 & .65 \\
Blue light & .004 & .010 \\
Age & .000 & .39 \\
SNP7 & .82 & .65 \\
Blue light & .004 & .010 \\
Age & .000 & .39 \\
SNP8 & .59 & .90 \\
Blue light & .006 & .010 \\
Age & .000 & .41 \\
\hline
\end{tabular}

HAL indicates $1439 \mathrm{~V}$ polymorphism of the histidase gene; R151C_R160W, the presence of either of the RHC alleles (R151C and R160W) of the MC1R gene; SNP6, the presence of any of the most frequent $6 \mathrm{MC} 1 \mathrm{R}$ polymorphisms (V60L, V92M, R151C, R160W, W1630, and I155T); SNP7, the presence of any of the SNP6 group and the rare I120T polymorphism; SNP8, presence of either of SNP7 and the newly identified W169R polymorphism.

${ }^{a}$ According to the results of the Kolgomorov-Smirnov test, the number of CMN + CAMN did not show normal distribution. Analysis of variance was therefore performed on the $\ln (\mathrm{CMN}+\mathrm{CAMN})$

${ }^{b}$ According to the results of the Kolgomorov-Smirnov test, the number of $\mathrm{IF}+\mathrm{IN}+\mathrm{CHN}$ did not show normal distribution, and because of the high numbers of 0 values in the survey, logistic regression was performed.

wavelengths of blue light and UV light are adjacent, and they might therefore exert partly similar biological effects. In addition to inducing melanocyte proliferation, UV irradiation has profound immunosuppressive and immunomodulatory effects, and it is well established that immunosuppression increases the risk of both nevus formation and melanoma development. In view of the special characteristics of newborn skin and the immune system, intensive NBLP may mean an acute shock-like attack on the immature melanocytes of the epidermis.

We also observed a significantly elevated number of IF among participants with anamnestic NBLP. The number of melanocytic lesions of the iris in our study proved to be age independent, which can be explained by the time 
course of iris pigmentation: the concentration of melanin peaks during early childhood, thereafter usually remaining constant throughout life, unless affected by certain ocular disorders, which can lead to hypopigmentation or hyperpigmentation. ${ }^{36,37}$ The eyes of phototreated infants are routinely patched to exclude eye burning. ${ }^{38,39}$ Although eye patching shields and phototherapy hoods are effective in reducing the intensity of incident light, accidental exposure may occur. ${ }^{40,41}$ Patches are prone to slip: there may be difficulties in securing eye shields effectively. Conversely, the precise patching of an infant's eye may be of secondary importance to more immediate and potentially lifepreserving interventions. Although the potential hazard of blue light is alleviated by the fact that neonates tend to keep their eyes shut in bright light, it is known that light in the visible spectrum penetrates the skin. The level of blue light transmission through the closed eyelids of infants cannot be assessed with accuracy. With regard to the light transmissibility profile of the neonatal cornea and crystalline lens, which allows the penetration of an appreciable amount of potentially harmful light into the eye, additional studies

\section{REFERENCES}

1. Csoma Z, Erdei Z, Bartusek D, et al. The prevalence of melanocytic naevi among schoolchildren in South Hungary. J Eur Acad Dermatol Venereol. 2008;22(12):1412-1422

2. Carli P, Biggeri A, Nardini P, Giannotti B. Sun exposure and large numbers of common and atypical melanocytic naevi: an analytical study in a southern European population. Br J Dermatol. 1998;138(3):422-425

3. Garbe C, Buttner P, Weiss J, et al. Associated factors in the prevalence of more than 50 common melanocytic nevi, atypical melanocytic nevi, and actinic lentigines: multicenter case-control study of the Central Malignant Melanoma Registry of the German Dermatological Society. J Invest Dermatol. 1994;102(5):700-705

4. Dennis LK, White E, Lee JA, et al. Constitu- are needed to clarify the possible longterm effects of neonatal blue light exposure on the melanocytic proliferation of the uveal tract. ${ }^{42,43}$ Our results indicate the importance of appropriate eye care and eye protection of infants receiving phototherapy. In the event of unavoidable phototherapy treatment, alternative methods of eye protection should be used to minimize accidental blue light exposure of the extremely vulnerable neonatal eye.

It is well established that both environmental and genetic factors contribute to melanoma-predisposing melanocytic nevus development. To investigate whether polymorphisms known to be associated with human pigmentation, melanoma predisposition ${ }^{25-27}$ and skin immune functions ${ }^{28-31}$ can enhance the effects of NBLP, we investigated several SNPs of the MC1R and HAL genes. The statistical analysis revealed that the examined polymorphisms of these genes do not contribute either to an elevated number of pigmented skin lesions or to the appearance of pigmented uveal lesions. In this respect, we failed to demonstrate any gene-environmental interactions in our cohort, although the study group was sufficiently large for the effects of MC1R polymorphisms on

tional factors and sun exposure in relation to nevi: a population-based cross-sectional study. Am J Epidemiol. 1996;143(3):248-256

5. Green A, Siskind V, Hansen ME, Leech P. Melanocytic nevi in schoolchildren in Queensland. J Am Acad Dermatol. 1989;20(6):1054-1060

6. Darlington S, Siskind V, Green L, Green A. Longjtudinal study of melanocytic nevi in adolescents. J Am Acad Dermatol. 2002;46(5):715-722

7. Gallagher RP, McLean DI, Yang CP, et al. Suntan, sunburn, and pigmentation factors and the frequency of acquired melanocytic nevi in children. Similarities to melanoma: the Vancouver Mole Study. Arch Dermatol. 1990;126(6):770-776

8. Hammer H, Tóth-Molńar E, OláH J, Dobozy A. Cutaneous dysplastic naevi: risk factor for uveal melanoma. Lancet. 1995;346(8969):255-256 the skin type to be detected. We cannot exclude the possibility that, through enlargement of our cohort, the contribution of some polymorphisms might become apparent, but the present findings clearly suggest that NBLP has a much more robust effect on the development of pigmented lesions compared with the possible contribution of genetic factors.

\section{CONCLUSIONS}

Our new epidemiologic data suggest that NBLP could well be a risk factor for melanocytic nevus development. Phototherapy with blue light lamps is currently a standard and essential therapeutic modality in neonatal care; additional studies are therefore necessary to establish its potential long-term adverse effects. We suggest that a more restricted treatment protocol should be introduced to rule out the unnecessary application of NBLP and thereby prevent its possible adverse effects.

\section{ACKNOWLEDGMENTS}

This study was supported by the ETT (National Fund of the Hungarian Ministry of Health) 429-07, the TÁMOP-4.2.2-08/12008-0001, the TÁMOP-4.2.1/B-09/1/KONV2010-0005, and the OTKA (Hungarian Scientific Research Fund) 5K302 grants.

9. Barnhill RL, Mihm MC, Ceballos PI. Angiogenesis and regressing cutaneous malignant melanoma. Lancet. 1992;339(8799): 991-992

10. Halpern AC, Guerry D, Elder DE, et al. Dysplastic nevi as risk markers of sporadic (nonfamilial) melanoma. A case-control study. Arch Dermatol. 1991;127 (7):995-999

11. Garbe C, Buttner P, Weiss J, et al. Risk factors for developing cutaneous melanoma and criteria for identifying persons at risk: multicenter case-control study of the Central Malignant Melanoma Registry of the German Dermatological Society. J Invest Dermatol. 1994;102(5):695-699

12. Slade J, Marghoob AA, Salopek TG, Rigel DS, Kopf AW, Bart RS. Atypical mole syndrome: risk factor for cutaneous malignant mela- 
noma and implications for management. $J$ Am Acad Dermatol. 1995;32(3):479-494

13. Krüger $S$, Garbe $C$, Buttner $P$, et al. Epidemiologic evidence for the role of melanocytic nevi as risk markers and direct precursors of cutaneous malignant melanoma. Results of a case control study in melanoma patients and nonmelanoma control subjects. $J$ Am Acad Dermatol. 1992;26 (6):920-926

14. Garbe C, Eigentler TK. Diagnosis and treatment of cutaneous melanoma: state of the art 2006. Melanoma Res. 2007;17(2):117-127

15. Smith JH, Padnick-Silver L, Newlin A, Rhodes K, Rubinstein WS. Genetic study of familial uveal melanoma: association of uveal and cutaneous melanoma with cutaneous and ocular nevi. Ophthalmology. 2007;114(4):774-779

16. Richtig E, Langmann G, Müllner K, Smolle J. Ocular melanoma: epidemiology, clinical presentation and relationship with dysplastic nevi. Ophthalmologica. 2004;218(2):111-114

17. Csoma Z, Hencz P, Orvos H, et al. Neonatal blue-light phototherapy could increase the risk of dysplastic nevus development. Pediatrics. 2007;119(5):1036-1037

18. Csoma Z, Hencz P, Orvos H, et al. Neonatal blue-light phototherapy could increase the risk of dysplastic nevus development. Pediatrics. 2007;119(6):1269

19. Maisels MJ, McDonagh AF. Phototherapy for neonatal jaundice. N Engl J Med. 2008; 358(9):920-928

20. Porter ML, Dennis BL. Hyperbilirubinemia in the term newborn. Am Fam Physician. 2002; 65(4):599-606

21. Dennery PA, Seidman DS, Stevenson DK, et al. Neonatal hyperbilirubinemia. $N$ Engl J Med. 2001;344(8):581-590

22. Bauer J, Buttner $\mathrm{P}$, Luther $\mathrm{H}$, et al. Blue light phototherapy of neonatal jaundice does not increase the risk for melanocytic nevus development. Arch Dermatol. 2004;140(4):493-494

23. Matichard E, Le Hénanff A, Sanders A, Leguyadec J, Crickx B, Descamps V. Effect of neo- natal phototherapy on melanocytic nevus count in children. Arch Dermatol. 2006; 142(12):1599-1604

24. MahÉ E, Bauchet A, Aegerter P, Saiag P. Neonatal blue-light phototherapy does not increase nevus count in 9-year-old children. Pediatrics. 2009;123(5). Available at: www. pediatrics.org/cgi/content/full/123/5/e896

25. Raimondi S, Sera F, Gandini S, et al. MC1R variants, melanoma and red hair color phenotype: a meta-analysis. Int $J$ Cancer. 2008;122(12):2753-2760

26. Kanetsky PA, Rebbeck TR, Hummer AJ, et al. Population-based study of natural variation in the melanocortin-1 receptor gene and melanoma. Cancer Res. 2006;66(18):9330-9337

27. Bishop DT, Demenais F, Iles MM, et al. Genome-wide association study identifies three loci associated with melanoma risk. Nat Genet. 2009;41(8):920-925

28. Hart PH, Jaksic A, Swift G, Norval M, el-Ghorr A, Finlay-Jones JJ. Histamine involvement in UVBand cis-urocanic acid-induced systemic suppression of contact hypersensitivity responses. Immunology. 1997;91(4):601-608

29. Beissert $S$, Rühlemann $D$, Mohammad $T$, et al. IL-12 prevents the inhibitory effects of cisurocanic acid on tumor antigen presentation by Langerhans cells: implications for photocarcinogenesis. J Immunol. 2001;167(11):6232-6238

30. Moodycliffe AM, Bucana CD, Kripke ML, Norval M, Ullrich SE. Differential effects of a monoclonal antibody to cis-urocanic acid on the suppression of delayed and contact hypersensitivity following ultraviolet irradiation. J Immunol. 1996;157 (7):2891-2899

31. Welsh MM, Karagas MR, Applebaum KM, Spenser SK, Perry AE, Nelson HH. A role for ultraviolet radiation immunosuppression in non-melanoma skin cancer as evidenced by gene-environment interactions. Carcinogenesis. 2008;29(10):1950-1954

32. English DR, MacLennan R, Rivers JK, Kelly J, Armstrong BK. Epidemiological Studies of Melanocytic Nevi: Protocol for Identifying and Recording Nevi. Lyon, France: International Agency for Research on Cancer; 1990. Internal report 90/002

33. Shields JA. Diagnosis and Management of Intraocular Tumors. St Louis, MO: CV Mosby; 1983

34. Széll M, Baltas E, Bodai $L$, et al. The Arg160Trp allele of melanocortin-1 receptor gene might protect against vitiligo. Photochem Photobiol. 2008;84(3):565-571

35. Csoma Z, Kemeny L, Olah J. Phototherapy for neonatal jaundice. N Engl J Med. 2008; $358(23): 2523-2524$

36. Imesch PD, Wallow IH, Albert DM, et al. The color of the human eye: a review of morphologic correlates and of some conditions that affect iridial pigmentation. Surv Ophthalmol. 1997;41 (suppl 2):S117-S123

37. Bito LZ, Matheny A, Cruickshanks KJ, et al. Eye color changes past early childhood: the Louisville Twin Study. Arch Ophthalmol. 1997;115(5):659-663

38. Chin KC, Moseley MJ, Bayliss SC, et al. Light transmission of phototherapy eyeshields. Arch Dis Child. 1987;62(9):970-971

39. Moseley H, Marshall J. Protective light shields for neonatal phototherapy. Lancet. 1988;2(8615):854-855

40. Fok TF, Wong W, Cheung KL. Eye protection for newborns under phototherapy: comparison between a modified headbox and the conventional eyepatches. Ann Trop Paediatr. 1997;17(4):349-354

41. Ostrowski G, Pye SD, Laing IA, et al. Do phototherapy hoods really protect the neonate? Acta Paediatr. 2000;89(7):874-877

42. Singh AD, Rennie IG, Seregard S, Giblin M, McKenzie J. Sunlight exposure and pathogenesis of uveal melanoma. Surv Ophthalmol. 2004;49(4):419-428

43. Shah CP, Weis E, Lajous M, et al. Intermittent and chronic ultraviolet light exposure and uveal melanoma: a meta-analysis. Ophthalmology. 2005;112(9):1599-1607

\section{(Continued from first page)}

www.pediatrics.org/cgi/doi/10.1542/peds.2011-0292

doi:10.1542/peds.2011-0292

Accepted for publication Jun 14, 2011

Address correspondence to Zsanett Csoma, MD, PhD, Department of Dermatology and Allergology, University of Szeged, P0 Box 427, H-6701 Szeged, Hungary. E-mail: csomazs@mail.derma.szote.u-szeged.hu

PEDIATRICS (ISSN Numbers: Print, 0031-4005; Online, 1098-4275).

Copyright @ 2011 by the American Academy of Pediatrics

FINANCIAL DISCLOSURE: The authors have indicated they have no financial relationships relevant to this article to disclose. 
Neonatal Blue Light Phototherapy and Melanocytic Nevi: A Twin Study Zsanett Csoma, Edit Tóth-Molnár, Klára Balogh, Hilda Polyánka, Hajnalka Orvos, Henriette Ócsai, Lajos Kemény, Márta Széll and Judit Oláh Pediatrics 2011;128;e856; originally published online September 19, 2011; DOI: $10.1542 /$ peds. $2011-0292$

\section{Updated Information \& Services}

References

Citations

Subspecialty Collections

Permissions \& Licensing

Reprints including high resolution figures, can be found at: http://pediatrics.aappublications.org/content/128/4/e856.full.h tml

This article cites 40 articles, 12 of which can be accessed free at:

http://pediatrics.aappublications.org/content/128/4/e856.full.h tml\#ref-list-1

This article has been cited by 1 HighWire-hosted articles: http://pediatrics.aappublications.org/content/128/4/e856.full.h tml\#related-urls

This article, along with others on similar topics, appears in the following collection(s):

Allergy \& Dermatology

http://pediatrics.aappublications.org/cgi/collection/allergy_an d_dermatology

Information about reproducing this article in parts (figures, tables) or in its entirety can be found online at:

http://pediatrics.aappublications.org/site/misc/Permissions.xht $\mathrm{ml}$

Information about ordering reprints can be found online: http://pediatrics.aappublications.org/site/misc/reprints.xhtml

PEDIATRICS is the official journal of the American Academy of Pediatrics. A monthly publication, it has been published continuously since 1948. PEDIATRICS is owned, published, and trademarked by the American Academy of Pediatrics, 141 Northwest Point Boulevard, Elk Grove Village, Illinois, 60007. Copyright @ 2011 by the American Academy of Pediatrics. All rights reserved. Print ISSN: 0031-4005. Online ISSN: 1098-4275.

\section{American Academy of Pediatrics}

DEDICATED TO THE HEALTH OF ALL CHILDREN ${ }^{m}$ 